\title{
PRETORIA STUDENT LAW REVIEW (2012) 6
}

Pretoria Tydskrif vir Regstudente Kgatišobaka ya Baithuti ba Molao ya Pretoria

\author{
Editor in chief: \\ Serena Kalbskopf \\ Editors: \\ Laura Schlebusch \\ Michele Dempster \\ Mark Nichol \\ Joel Modiri \\ Kenneth Sithebe \\ Petronell Kruger
}

Pretoria University Law Press PULP

2013 


\section{(2012) 6 Pretoria Student Law Review}

\section{Published by:}

Pretoria University Law Press (PULP)

The Pretoria University Law Press (PULP) is a publisher, based in Africa, launched and managed by the Centre for Human Rights and the Faculty of Law, University of Pretoria, South Africa. PULP endeavours to publish and make available innovative, high-quality scholarly texts on law in Africa. PULP also publishes a series of collections of legal documents related to public law in Africa, as well as text books from African countries other than South Africa.

For more information on PULP, see www.pulp.up.ac.za

Printed and bound by:

Ultra Litho (Pty) Ltd

Johannesburg

Cover:

Layout: Yolanda Booyzen, Centre for Human Rights

Cover design: Michele Dempster

Photograph on back cover: Togo Ntokozo Langa

To submit articles, contact:

PULP

Faculty of Law

University of Pretoria

South Africa

0002

Tel: +27 124204948

Fax: +27 123625125

pulp@up.ac.za

www.pulp.up.ac.za

ISSN: $1998-0280$ 


\section{TABLE OF CONTENTS}

Editors' note 4

Serena Kalbskopf

What is 'academic legal writing' $\quad 7$

Danie Brand

Police misconduct and delictual liability:

A discussion on developing vicarious

liability jurisprudence through a focus on the $K$ and $F$ cases

Kameel Premhid

Ubuntu in a post-apartheid South African context 33 Cornelia van Graan

Voetstoots ter uitsluiting van aanspreeklikheid $\quad 49$ Johannes Jacobus van der Walt

Tug of war: Evaluative versus facilitative mediator 69 Diksha Munjal

Voetstoots - Sale of immovable property, the law of legend?

Jean-Ray Pearton

The ANC's land reform policy: An unsustainable and unsatisfactory compromise

Thorne A Godinho 


\section{EDITORS' NOTE}

The sixth edition of the Pretoria Student Law Review truly signifies the journal's commitment to servicing students. Our journal's editorial policy was redrafted, introducing a faculty-supported Editorial Board, all in service of constructing a system that would best serve students who have a desire to write, notwithstanding our strong developmental emphasis.

Following the departure made in the previous edition, the 2012 journal includes the best written pieces submitted in conjunction with the University of Pretoria's Law Faculty Festival. The 'Write On' encouraged students to submit pieces based on the theme of 'What is Law' and provided an avenue for many students who had never thought of legal writing outside of their prescribed curriculum. Beyond the University of Pretoria's own faculty, this edition includes submissions from the National Law University Delhi and the University of KwaZulu-Natal.

Mention and thanks must be made to the various reviewers who have assisted the Editorial Committee. We have been fortunate to have reviewers from a variety of tertiary institutions including Stellenbosch and UNISA.

Finally, thank you to Professor Brand for his constant assistance throughout the year. To the various committee members, special thanks to Michele for the design of the cover, Joel for his insight on the editorial process, Mark for his long term commitment to the journal, Kenneth for his great work and Petronell for all her patience.

It is our hope that you are not only able to grasp greater insight into current legal developments, but also that our efforts represent our strong commitment and support to student writing.

Serena Kalbskopf

(Editor-in-chief 2012) 


\section{NOTE ON CONTRIBUTIONS}

We invite all students to submit material for the sixth edition of the Pretoria Student Law Review. We accept journal articles, case notes, commentary pieces, response articles or any other written material on legal topics. You may even consider converting your research memos or a dissertation chapter into an article.

Please visit our website at www.pslr.co.za for more information.

You may submit your contribution to pslr@up.ac.za.

Alternatively you may submit your contribution by hand at the office of the Dean of the Law Faculty:

Dean's Office

Faculty of Law

4th Floor

Law Building

Unversity of Pretoria

Pretoria

0002 



\section{WHAT IS ‘ACADEMIC LEGAL WRITING’?}

By Danie Brand*

\section{Introduction}

In the editors' note to the inaugural edition of the Pretoria Student Law Revie (PSLR) the editors wrote that the purpose of the PSLR is to serve as a platform for students to engage in 'academic legal writing'. To students interested in publishing in the PSLR, or any other law journal for that matter this might raise the questions: 'What is academic legal writing?'; 'Are there other forms of legal writing?'; and 'If so, how are they different from academic legal writing?'

These are important questions. They certainly do not only arise for potential student authors for the PSLR, but all law students who at some stage of their studies have to write 'academic' essays or dissertations, somehow different from 'practical' exam and test answers or pleadings for moot courts, or pretend-contracts. They also confront legal academics on a daily basis when they think about the nature and purpose of their work. I attempt here some answers to them.

\section{Different kinds of legal writing}

As any kind of 'doing' law - whether legal practice in whatever form; teaching law; or legal academia - centrally involves writing and the research that undergirds it, let me start by trying to identify different kinds of legal writing. I would say that there are four.

First, there is legal writing in practice. Whether one practices as an advocate; an attorney; a judicial officer or a legal advisor or whatever else, a central part of one's work will be writing and research. Advocates (and sometimes attorneys) write pleadings, affidavits, opinions and memoranda; attorneys draft notices of different kinds, contracts and memoranda; judicial officers write judgments; legal advisors give their advice on the basis of research and in writing.

Second, there is legal writing for practice. Practitioners or sometimes legal academics write what are generally called reference

* Associate Professor in Public Law, University of Pretoria. 
works for use in practice - authoritative statements of the positive law on a topic at a given time that practitioners can use in their day to day work to determine the current legal position on a point or to remind them of a process or form to follow. Examples of such reference works that emanate from my Faculty at UP are Van Loggerenberg's well-known Jones \& Buckle: The civil practice of the magistrates' courts in South Africa ${ }^{1}$ and Harms' Amler's precedents of pleadings. ${ }^{2}$

Third there is legal writing for education. All law students are during their studies exposed to textbooks on different topics - books written for use by law teachers in their teaching and law students in their studying. Examples would be Van der Walt and Pienaar's Property law ${ }^{3}$ and Theophilopoulos, Van Heerden and Boraine's Fundamental principles of civil procedure. ${ }^{4}$

Fourth and finally there is academic, or as it is also called, scholarly legal writing - the writing that legal academics, sometimes practitioners and often law students engage in for postgraduate research (doctoral theses, LLM dissertations) or for academic publication in journals or as books. Examples of scholarly/academic journal articles in South Africa would be Klare's 'Legal culture and transformative constitutionalism' $; 5$ Cockrell's 'Substance and form in the South African law of contract'; 6 and Davis' 'Adjudicating the socio-economic rights in the South African constitution. Towards "deference lite"'? 9 Examples of scholarly books in turn are Malan's Politocracy ${ }^{8}$ and Van der Walt's Property in the margins. ${ }^{9}$

\section{The distinction}

How does this last category of legal writing - academic/scholarly writing - differ from writing in and for practice and educational legal writing? Stated differently, how should prospective authors for the PSLR determine whether they are indeed engaging in the kind of 'academic legal writing' that the editors of the journal expect of them?

There are two bases upon which to my mind one can distinguish academic/scholarly from other kinds of legal writing - the nature of

\footnotetext{
DE van Loggerenberg (ed) Jones \& Buckle: The Civil Practice of the Magistrates' Courts in South Africa (10th ed 2012).

LT Harms Amler's precedents of pleadings (7th ed 2009).

AJ van der Walt \& GJ Pienaar Property law (6th ed 2009).

C Theophilopoulos, CM van Heerden \& A Boraine Fundamental principles of civil procedure ( $2 \mathrm{~d}$ ed 2012 ).

(1998) 14 South African Journal on Human Rights 146.

(1992) 109 South African Law Journal 40.

(2006) 22 South African Journal on Human Rights 301.

K Malan Politocracy (2012).

AJ van der Walt Property in the margins (2009).
} 
the writing and the research on which it is based and the basic purpose of the writing.

\subsection{A distinction in nature}

Writing in practice, writing for practice and educational legal writing all share a similar nature - they are all basically descriptive and analytical in nature. When an advocate prepares for and drafts the pleadings for a trial, she seeks in the first place to describe the existing law on point accurately and then to analyse that law to assess how it applies to the facts of her case. Retired judge Louis Harms, when he updates his Amler's precedents and pleadings, equally in the first place attempts to describe the existing law accurately and in an up-to-date fashion and then to analyse that law so that he can present it to practitioners in a useful fashion. Andre van der Walt and Gerrit Pienaar, when working on a new edition of their Property law also attempt to describe and analyse the existing law of property in such a fashion that it is clear to students and lecturers can use it to explain and teach.

Although good academic writing will always contain a healthy dose of description and analysis its basic nature is not in the first place descriptive and analytical. Instead, the description and analysis that one finds in academic writing stands in service to its real nature. Academic writing is different from other forms of legal writing in that it is primarily conceptual or theoretical in nature - when writing academically one seeks to engage on a conceptual/theoretical level with the law (that one inevitably also has to describe and analyse, of course) rather than that one seeks to describe and analyse alone. What does this mean? Lourens du Plessis, a prominent South African purveyor of academic/scholarly legal writing once described a theoretical or conceptual approach as one that does not have an immediate, descriptive relationship with its subject matter, but instead takes one step back from the immediate and attempts to generate general explanations or justifications for its subject matter; or to critique existing such general explanations or justifications; or to identify the principles upon which a particular area of law is based or to critique existing such principles. ${ }^{10}$ Academic/scholarly legal writing shows this basic approach to its subject matter. When Karl Klare wrote his 'Legal culture and transformative constitutionalism' in 1998, he certainly described and analysed in the first place the text of the 1996 South African Constitution and a series of decisions of the Constitutional Court. But he then went further: he sought to develop a general explanation for the constitution and constitutional adjudication, an over-arching approach of 'transformative 
constitutionalism'. When André van der Walt more recently wrote his Property in the margins he certainly started by providing an expert description and analyses of his subject matter - property law - but he then went further and developed a general theory of property law that conceptualises it from the perspective of those at the margins of society rather than, as is usually the case, from the perspective of the propertied, those at the centre of society.

\subsection{A distinction in purpose}

Writing in and for practice and educational legal writing all have a distinct utilitarian and practical purpose. An advocate writing a legal opinion on brief from an attorney does research and writes to address and resolve a practical legal problem raised by a case or dispute in real life. Danie van Loggerenberg when working on a new service of Jones and Buckle aims to present the current position in procedure in the magistrates' courts in such a way that practitioners can easily access and use that information in their daily practical work. Andre Boraine when he and his colleagues work on a new edition of the procedural law textbook will try to present it in such a fashion that the information can be understood and internalised by law students so that they have the basic knowledge and skill about civil procedure that they require to enter some form of legal practice - their purpose is educational.

Academic/scholarly legal writing in turn has a different, much less utilitarian and perhaps more amorphous purpose. Here is where others might disagree with me, but to mind legal writing is only scholarly/academic if it has as its primary purpose the development of legal thought and legal theory - in my own context, if it has as its primary purpose the development of South African legal thought and theory. When Koos Malan wrote his book 'Politocracy' he sought to develop an overarching theory of the law relating to living together in a multicultural society in order to contribute to the development of the law in that respect - indeed, he makes proposals for new ways of regulating public decision making and lawmaking in this context. When Dennis Davis wrote his 'Adjudicating the socio-economic rights in the South African constitution. Towards "deference lite"' he described and analysed the socio-economic rights jurisprudence of the South African Constitutional Court not simply to provide a description of that area of law, but so that he could identify the underlying principles and approach informing that jurisprudence, critique it and propose a different overarching theoretical approach. The purpose is in other words not in the first place as with other forms of legal writing practical, to contribute to the practice of law, but to contribute to the broader development of law, legal thought and theory. 


\section{Conclusion}

The distinction that I describe above should of course not be applied too rigidly. Two points to qualify it. The first is that, whatever the difference between academic and other kinds of legal writing, it is not one of quality but one of kind. It might be that some practitioners in principle sniff at the work that academics do and that some academics dismiss the writing and research of practitioners out of hand. If that happens, that is simply reciprocal snobbery or professional jealousy. The truth is that there is excellent research and writing in both practice and academia, just as there is in both contexts some pretty bad or average writing and research - but good or bad, research and writing of different kinds. Indeed, as any good practitioner or academic will profess, pure academic writing is often very useful for practitioners, just as pure practical writing can be very instructive for academics (although whether this is the case is no measure of the quality of either!).

The second is that whatever conceptual distinction one can make between academic and other kinds of legal research and writing cannot be absolute - as no distinction or categorisation can be watertight. Whichever basis one chooses for the distinction, there is bound to be a large measure of overlap between the different genres of legal writing $-\mathrm{a}$ book might for example be both a practitioners' reference work and a student textbook, or, more to the point, a practitioners' reference work might show some characteristics of a scholarly/academic work. The most one can say is that an academic work is one that primarily shows certain characteristics, rather than that those characteristics are an add-on to some other basic nature. To extend this point, practitioners can and do certainly sometimes engage in scholarly writing, just as academics often engage in writing in and for practice: of the three examples of scholarly articles I mentioned above, one (Cockrell's) was written by an advocate at the Johannesburg Bar and another (Davis') by a sitting judge. And perhaps this is the point - if you are to work in law one day in whatever capacity you will inevitably write and write a lot. It will be important to know for whom and for what purpose you write - what kind of legal writing you engage in - so that you ensure that your writing fits its particular context. But in the end the most important thing would remain to do whatever kind of legal writing you end up in carefully and well. 



\title{
POLICE MISCONDUCT AND DELICTUAL LIABILITY: A DISCUSSION ON DEVELOPING VICARIOUS LIABILITY JURISPRDUENCE THROUGH A FOCUS ON THE $K$ AND $F$ CASES
}

\author{
By Kameel Premhid*
}

\section{Introduction}

Despite progress made by South African courts with respect to the 'sufficiently close connection' requirement to establish vicarious liability, most notably in the judgment of the Constitutional Court (CC) in $K v$ Minister of Safety and Security, ${ }^{1}$ the question remains whether our judges have accepted this ground-breaking precedent and apply it in the spirit it was intended. ${ }^{2}$

In focusing on the minority dissenting judgment in $F v$ Minister of Safety and Security $(F)^{3}$ written by Yacoob J (with Jafta J concurring), I address wider issues that exist with respect to the sufficiently close connection requirement of vicarious liability as established by $K$. As part of this discussion, I also proceed to: (1) set out the material facts of $F$; (2) give an overview of the current law applicable to vicarious liability and show where $F$ fits into that framework; (3) briefly discuss all the judgments of the Constitutional Court with respect to the framework of vicarious liability as provided; and (4) offer a critique of the minority dissenting judgment with the aim of making more general comments about the sufficiently close connection requirement in the case of (standby duty) policemen. It is submitted that some of the factors considered in the context of policemen could potentially be applicable in other scenarios where the question of a sufficiently close connection for the purposes of vicarious liability arises.

* $\quad$ BA LLB (University of KwaZulu-Natal), KZN Rhodes Scholar-Elect 2012 and Intern at the Helen Suzman Foundation.

$1 \quad K$ v Minister for Safety and Security 20056 SA 419 (CC)

J Neethling \& JM Potgieter 'Delictual state accountability for police rape' (2012) 9 LitNet Academic http://www.litnet.co.za/Article/deliktuele-staatsaanspreeklik heid-weens-polisieverkragting_(accessed 26 April 2013).

$3 \quad F \vee$ Minister of Safety and Security 20121 SA 536 (CC). As per footnote 2 of Mogoeng CJ's judgment, the Court still referred to the Minister as the Minister of Safety and Security even though the Minister's portfolio had been renamed to the Ministry of Police. 
With reference to the critique and commentary offered, I will conclude by illustrating how courts can overcome 'semantic discussions of the meanings of the 'course and scope' ... requirements' ${ }^{4}$ within the existing vicarious liability framework. It is hoped that when a court is adjudicating such a dispute it will apply the principles of vicarious liability in such a way that will

take into account the importance of the constitutional role entrusted to the police and the importance of nurturing the confidence and trust in the police, in order to ensure that their role is successfully performed. ${ }^{5}$

\section{Material facts 6}

This case was an appeal heard from the Supreme Court of Appeal (SCA). ${ }^{7}$ The SCA in turn heard this matter on appeal from the Western Cape High Court (High Court) where the matter was argued before Bozalek J. ${ }^{8}$

The facts are as follows: Van Wyk, the second respondent in this matter, ${ }^{9}$ was a detective on standby duty during the evening and/or early morning of $14 / 15$ October $1998 .{ }^{10}$ Van Wyk met Ms $F$, a 13 year old minor girl child at the time, at a nightclub. Van Wyk was at the nightclub despite being on standby duty. $F$ was in need of a lift and thus accepted his assistance. ${ }^{11}$ Van Wyk was at the time in possession of an unmarked police vehicle to enable him to discharge any police functions that he might be required to perform. ${ }^{12}$ Van Wyk also transported two other passengers whilst giving $\mathrm{F}$ a lift, one of whom was known to her. ${ }^{13}$ Van Wyk dropped off the other passengers at their respective homes. At the request of Van Wyk, F moved into the front seat of the vehicle at which point she noticed police dockets on the seat. In reply to her question as to whether he was a policeman, Van Wyk responded that he was a private detective. $\mathrm{F}$ took this to mean that he was a policeman. ${ }^{14}$

Despite his undertaking to take her home, Van Wyk aroused F's suspicions when he drove towards Kaaimansrivier, away from her

\footnotetext{
M Loubser \& R Midgley (eds) The law of delict in South Africa (2009) 379. K (n 1 above) para 52.

Loubser and Midgley (n 4 above) 379.

$F$ (note 3 above). The facts of the case appear more fully from the judgment but are canvassed here briefly. Specifically see paras 8 - 25 and $157-162$.

Minister of Safety and Security v F 2011 (3) SA 487 (SCA).

$F \vee$ Minister of Safety and Security 2010 (1) SA 606 (WCC).

$F$ (note 3 above).

$F$ (n 3 above). Appellant's Heads of Argument para 57.

$F$ (n 3 above) para 8.

$F$ (n 3 above) para 9.

$F$ (n 3 above) para 8.

$F$ (n 3 above) para 10.
} 
home. ${ }^{15}$ Van Wyk assured her that they would be a short time as Van Wyk just wanted to visit friends. Given her suspicions, F escaped from the vehicle and hid. Van Wyk then seemingly departed and F sought another lift. Her position being desperate and in need, gave rise to the subsequent rape and assault that Van Wyk subjected her to, as when he approached her the second time, despite her suspicions, she accepted a lift from him. ${ }^{16}$

The CC accepted her evidence that she trusted him to deliver her to her home, despite her suspicions, by virtue of him being a policeman. ${ }^{17}$ Upon her second attempt at escaping, Van Wyk managed to prevent her from doing so and then proceeded to rape and assault her. He then dropped $\mathrm{F}$ off at her home after threatening her with death should she report it to the authorities. ${ }^{18}$ Despite these threats, F laid criminal charges against him. Van Wyk was convicted and sentenced to 12 years' imprisonment ( 5 of which were suspended). ${ }^{19}$ In December 2005, F sought to launch proceedings to recover damages from the Minister and Van Wyk himself. ${ }^{20}$

In order to fully understand how these facts were interpreted differently and why clarity on the sufficiently close connection test is needed, a brief overview of the case history of this matter before it was heard in the apex court is necessary.

\section{Case history}

\subsection{The High Court}

In the High Court, the applicant (F) was successful in her claim for damages against the Minister (first respondent) and Van Wyk (second respondent). Whilst it is obvious that $\mathrm{F}$ had a delictual claim against Van Wyk, the Court, as per Bozalek J, found the Minister to be vicariously liable for Van Wyk's conduct. Bozalek J made this finding through an application of the sufficiently close connection test as established in $K$. As an indication of this link, Bozalek $\mathrm{J}$ cited three factors: (a) Van Wyk being provided with a police vehicle (even if unmarked) by his employer enabled the delict to be committed; (b) the fact that $F$ trusted Van Wyk by virtue of his status as a policeman - the condition without which she would have not allowed herself to be in such a position in the first place; and (c) the overlap

$F$ (n 3 above) para 11

$F$ (n 3 above) para 12

$F$ (n 3 above) para 13.

$F$ (n 3 above) para 14

$F$ (n 3 above) para 15.

$F$ (n 3 above) para 16. 
between Van Wyk's mala fide offer of assistance and his official duties as a policeman. ${ }^{21}$

\subsection{The Supreme Court of Appeal}

Having been granted leave to appeal, the Minister sought to have the court a quo's decision set aside. The SCA found by a 3 - 2 majority, as per Nugent JA, that the Minister was not vicariously liable.

Nugent JA overturned the decision of the court a quo on the following grounds: (a) $K$ was distinguishable for two reasons: (i) the policemen in $K$ were on duty; and (ii) an off duty policeman has 'no duty to protect members of the public ... This is so because the police do not have an ongoing duty to protect members of the public. And in the absence of a duty ... there could be no personal liability on him;'22 (b) that $K$ did not extend to positive delictual acts but only to acts of omission and that because Van Wyk was not on duty he could not have 'breached his duty to protect $\mathrm{F}$ when he committed the rape. ${ }^{23}$

\subsection{The tension between the SCA and CC majorities}

This case when then taken on a further appeal to the Constitutional Court. Mogoeng $\mathrm{CJ}$, writing on behalf of the majority who overturned the SCA's decision, stated that the majority in the SCA understood $K$ to apply because the policemen 'committed a delict of omission' and failed to protect $\mathrm{K}$ whilst 'they were on duty and under an obligation to do so. ${ }^{24} \mathrm{He}$ notes on behalf of the majority that they 'reject(s) any notion that a policeman could be ... "engaged in the affairs of his employer" when he commits a rape' or that it could be regarded as "an "improper mode" of the authority conferred on him by the employer.'

Mogoeng $\mathrm{CJ}$ found the judgment of the SCA minority (written by Maya JA) to be more persuasive. He favourably summarised her judgment as follows: '... although the rape had nothing to do with (his) official duties, there was a sufficiently close link between his acts for personal gratification and the police. ${ }^{25}$ Mogoeng CJ placed significant emphasis on Maya JA's finding that F only trusted Van Wyk

$21 \quad F$ (n 3 above) para 18. Further, see Applicant's Affidavit para 12.

$22 F$ (n 3 above) para 20 . The implication of this argument although not expressly summarised by Mogoeng CJ as such, is that in the absence of a personal duty to protect $F$, when Van Wyk raped her, he did so as a private citizen and thus by extension, no vicarious liability extends to the Minister.

$23 \quad F$ (n 3 above) paras $20 \& 22$.

$24 F$ (n 3 above) para 21

$25 \quad F$ (n 3 above) para 23. 
by virtue of the fact that he was a policeman and that when he offered $\mathrm{F}$ a lift, he placed himself on duty. ${ }^{26}$

It is this difference which allowed the minority of the SCA and the majority of the CC to differ on the merits of F's case in the context of the applicability of $K$.

\section{The current position on vicarious liability 27}

Vicarious liability is considered to be a form of strict liability where the employer is held liable for the wrongdoing of the employee. ${ }^{28}$ The employer is held to be jointly liable when the delict is committed within the course and scope of employment ${ }^{29}$ or where they undertake any activities incidental to it. ${ }^{30}$ There are many theories which explain the existence of vicarious liability but the general position is that where a particular relationship of employment exists, ${ }^{31}$ and the employee, in the pursuance of his objectives of employment, commits a delict, the employer shall bear joint responsibility for the offending conduct. ${ }^{32}$

Delicts committed while going about the employer's business are regarded as the standard cases. Where however the wrongdoing ostensibly takes place outside the course and scope of the employment relationship, i.e. the so called deviation cases, 33 liability may still be imputed to the employer where there is a sufficiently close connection that can be established between the wrongful act and the employment. This was established in $K$ which can be credited

6 Ibid

$27 \quad F$ (n 3 above) paras 40 - 50. Mogoeng CJ sets out the development of vicarious liability in detail in his judgment.

Loubser \& Midgley (n 4 above) 367.

Loubser \& Midgley (n 4 above) 367.

$F$ (n 3 above) para 40 . Mogoeng $C \mathrm{~J}$ in footnote 26 lists cases which illustrate that principle: Ess Kay Electronics Pte Ltd and Another $v$ First National Bank of Southern Africa Ltd 2001 1 SA 1214 (SCA) (Ess Kay Electronics) para 7 (which dealt with whether an employee of the bank who stole and forged two banker's drafts acted within the course and scope of his employment); and ABSA Bank Ltd $v$ Bond Equipment (Pretoria) (Pty) Ltd 20011 SA 372 (SCA) para 5 (which also dealt with a similar question with respect to the unlawful conduct of an employee and whether that qualified in terms of the course and scope test).

Neethling, Potgieter \& Visser Law of Delict (4th edition) (2001) 373

The requirements of vicarious liability are set out differently but have the employer-employee relationship and committing the delict within the course and scope of the employment in common. Neethling et al (n 31 above) $374-379$ list 3 requirements, namely: (1) there must be an employer-employee relationship at the time when the delict is committed; $(2)$ the employee must commit a delict; and (3) the employee must act within the course and scope of his employment when the delict is committed. This is different to Loubser \& Midgley ( 4 above) 369 - 370; 374 - 376 who list 2 requirements, namely: (1) an employment or akinto-employment relationship must exist; and (2) the delict must be committed by $33 \quad F$ (n 3 above) para 41 . 
with reforming the vicarious liability test to bring it in line with constitutional demands of the Bill of Rights. ${ }^{34}$

\subsection{The position with respect to vicarious liability cases is as follows}

In Feldman (Pty) Ltd $v$ Mall, ${ }^{35}$ the Appellate Division ('AD') held that an employer could be held liable for the delicts of an employee even where employees are 'inefficient or untrustworthy' in satisfying their employment obligations because 'employees are extensions of their employers' and that 'employers could be held to have created a risk of harm to others. ${ }^{36}$ It seems that this dictum could apply so widely that even where they 'act inconsistently with their employer's core business' they could still be liable where 'some link between the employer's business and the delictual conduct (may) be established. ${ }^{37}$ The main idea to take away from this case is not the idea of the creation of risk, ${ }^{38}$ but rather that an employee can bind an employer for their delictual acts if in carrying out their employment they act in an imperfect manner. ${ }^{39}$ This case contributed to our understanding of typical vicarious liability scenarios.

Further, in Minister of Police $v$ Rabie ${ }^{40}$ the test for vicarious liability was further developed and reformulated in these terms:

It seems clear that an act done by a servant solely for his own interests and purposes, although occasioned by his employment, may fall outside the course or scope of his employment, and that in deciding whether an act by the servant does so fall, some reference is to be made to the

$F$ (n 3 above) para 48.

Feldman (Pty) Ltd $v$ Mall 1945 AD 733. Briefly, this case dealt with the situation where an employee driver whilst on official duty deviated from his official duties and catered to his personal affairs which inter alia involved consuming alcohol which impaired his driving abilities. When he resumed official duties and was returning to work, he negligently collided with and killed a man with two minor dependents. This case centered on whether the company was vicariously liable for the dependants' claim for damages.

36 Loubser \& Midgley (n 6 above) 367.

$37 \quad F$ (n 3 above) paras $42,44-45$

$\mathrm{K}$ Calitz "Vicarious liability of employers: reconsidering risk as the basis for liability' (2005) 3 TSAR 215, 231. Calitz opines that whilst the idea of risk as the basis of vicarious liability is 'not alien to South African jurisprudence' it has not been 'thoroughly examined' and as such was 'rejected in later decisions.' In footnote 96 she references two cases as authority: $R \vee$ Ngobo 19924 SA 822 (A) 39 and Ess Kay Electronics (note 30 above) para 40.

$39 \mathrm{~S}$ Wagener ' $\mathrm{K} \vee$ Minister of Safety and Security and the increasingly blurred line between personal and vicarious liability' (2008) SALJ 674.

40 Minister of Police $v$ Rabie 19861 SA 117 (A). Briefly, this case dealt with the situation where an off-duty employee policeman (who was a mechanic) wrongfully arrested, detained and assaulted the respondent in pursuit of his personal interests. The mechanic-policeman even went so far as to identify himself as a policeman despite being off duty and not in uniform. This case, heard on appeal, centred on whether the Minister was vicariously liable for the claim for damages where the conduct complained of radically deviated from the tasks directly and indirectly connected to the wrongdoers' employment. 
servant's intention. The test is in this regard subjective. On the other hand, if there is nevertheless a sufficiently close link between the servant's acts for his own interests and purposes and the business of his master, the master may yet be liable. This is an objective test. ${ }^{41}$

This reformulation allowed our Courts to adjudicate on so-called 'deviation' cases where the wrongful act was, prima facie, outside the employment relationship.

The Rabie 42 test was essential to the subsequent development of that developed in $K .{ }^{43}$ This can be seen as follows:

The approach makes it clear that there are two questions to be asked. The first is whether the wrongful acts were done solely for the purposes of the employee. This question requires a subjective consideration of the employee's state of mind and is a purely factual question. Even if it is answered in the affirmative, however, the employer may nevertheless be liable vicariously if the second question, an objective one, is answered affirmatively. That question is whether, even though the acts done have been done solely for the purpose of the employee, there is nevertheless a sufficiently close link between the employee's acts for his own interests and the purposes and the business of the employer. This question does not raise purely factual questions, but mixed questions of fact and law. The questions of law it raises relate to what is 'sufficiently close' to give rise to vicarious liability. It is in answering this question that a court should consider the need to give effect to the spirit, purport and objects of the Bill of Rights. ${ }^{44}$

Cases like $F$ bring the $K$ test into sharp perspective because even though it is obvious that the conduct of Van Wyk would traditionally exclude vicarious liability as his wrongful conduct could never be in the interests of his employer, the possibility exists that if the second question is answered affirmatively - and a sufficiently close link is found to exist - then the Minister could still be found liable. O'Regan $\mathrm{J}$, in a powerful judgment, developed several factors that a court should evaluate in order to determine whether a sufficiently close link existed. They are: (1) the state's constitutional obligations to protect the public; (2) the trust that the public is entitled to place in the police; (3) the significance, if any, that the policeman may be off duty or on standby duty; (4) the role of the policeman's commission of the rape and omission to protect the victim; and (5) the existence of an intimate link between the policeman's conduct and his employment. These elements are complimentary and all work together to prove vicarious liability. ${ }^{45}$

\footnotetext{
Rabie (n 40 above) 134 C - E; F (n 3 above) para 47.

$F$ (n 3 above) para 49.

$K$ (n 1 above). Briefly, the question posed by this case was whether the State could be held vicarious liable where 3 on duty policemen (who were in uniform and utilising a marked police vehicle) raped a woman that they had offered to give a lift to after she had been separated from her party at a nightclub.

45 (n 3 above) para 52.
} 
The question then for the Constitutional Court then is whether the $K$ test can be extended to a standby duty policeman. Even though the $C C$ in $F$ did find that it could - the minority dissenting judgment illustrates that in practice, in the absence of further considerations to supplement the test, the opportunity for doubters of $K$ still exists to not apply it. In as much as judicial dissent and disagreement can and must be encouraged in furthering our law, ${ }^{46}$ especially when the minority judgment is radical in its thinking and acts as the foundation for future developments of the law, we must be wary where such dissent could have the effect of retarding the advancement that we have made.

\section{Judgments of the Constitutional Court}

\subsection{Majority judgment}

Mogoeng $\mathrm{CJ}$ writing on behalf of the majority, ${ }^{47}$ found the Minister to be vicariously liable. Mogoeng CJ established this through an examination of each of the factors laid down in K. Mogoeng CJ's findings can be summarised as follows: ${ }^{48}$

- On the question of the state's constitutional obligations to protect the public Mogoeng $\mathrm{CJ}$ held that the police do have a significant duty to protect women and girls specifically from the 'plague of violent crimes' and that their 'fundamental rights are not made hollow by actual or threatened sexual violence'. ${ }^{49}$ While Courts may have fashioned the rules of vicarious liability according to common law, they must now ensure that those rules apply and are defensible in a society guided by our constitutional norms and standards. ${ }^{50}$ This is encapsulated by section $205(3)$ of the Constitution, ${ }^{51}$ which states that the objects of the police are to, inter alia, 'promote, combat and investigate crime ... and to uphold and enforce the law'. ${ }^{52}$ This provides a constitutional basis upon which to hold the State liable should this duty of police to combat crime and enforce the law be breached.

- With respect to the trust that the public is entitled to place in the police, Mogoeng CJ found that:

46 M Ryder 'The value of dissent' The Guardian 16 November 2012 http:// www.guardian.co.uk/law/2010/nov/16/dissenting-judgments-radmacher-hale (accessed 26 April 2013).

47 Moseneke DCJ, Cameron J, Khampepe J, Nkabinde J, Skweyiya J and Van der Westhuizen $\mathrm{J}$ concurring.

$48 \quad F$ (n 3 above) para 53 - 82. The Chief Justice engages in a very detailed explanation. As far as possible, the author has tried to summarise each factor so as to convey the full finding of Mogoeng $\mathrm{CJ}$ in his drawing the inevitable conclusion that the Minister is vicarious liable.

$49 \quad F$ (n 3 above) para 57

$50 \quad F$ (n 3 above) para 57

51 Constitution of the Republic of South Africa, 1996.

$52 \quad F$ (n 3 above) para 59. 
the employment of someone as a police official may rightly be equated to an invitation extended by the police service to the public to repose their trust in that employee. When a policeman abuses the trust placed in him by ... by raping ... a link may well be established between the employee's employment and the delict. ${ }^{53}$

- As to the significance of the fact that that the policeman may be on/ off or on standby duty, Mogoeng CJ stated that:

[He accepts] that a distinction between a policeman who is on duty and one who is off duty is a relevant factor in determining the closeness of the connection (but that he) does not accept it is determinative of [liability] ... [especially where F] was led to believe that a policeman, whether on or off duty, assumed the responsibility to protect her [which was] sufficient to let her guard down. ${ }^{54}$

- Given that the SCA distinguished the applicability of $K$ on the grounds that they believed it to only apply in the case of omissions, ${ }^{55}$ it is important to note Mogoeng CJ's quoting of $K$ :

[The] conduct of the policemen which caused harm constituted a simultaneous commission and omission. The commission lay in their brutal rape of the applicant. Their simultaneous omission lay in their failing while on duty to protect her from harm, something which they bore a general duty to do, and a special duty on the facts of this case. In my view, these three inter-related factors make it plain that viewed against the backdrop of our Constitution, and, in particular, the constitutional rights of the applicant and the constitutional obligations of the respondent, the connection between the conduct of the policemen and their employment was sufficiently close to render the respondent liable. ${ }^{56}$

Mogoeng CJ goes on to describe the interplay between the role of the policeman's commission of the rape and omission to protect the victim as being 'two sides of the same coin and both stem from and revolve around the same incident';57

- Lastly, on the question of the existence of an intimate link between the policeman's conduct and his employment, the Chief Justice again quotes from $K:{ }^{58}$

When the policemen ... raped the applicant, they were simultaneously failing to perform their duties to protect the applicant. In committing the crime, the policemen not only did not protect the applicant, they infringed her rights to dignity and security of the person. In so doing, their employer's obligation (and theirs) to prevent crime was not met. There is an intimate connection between the delict committed by the policemen and the purposes of their

$F$ (n 3 above) para 64. Mogoeng $C J$ went on to quote from $K$ as follows: 'the opportunity to commit the crime would not have arisen but for the trust the (Minister) placed in them because they were policemen.' $K$ ( $\mathrm{n} 1$ above) para 57. $F$ (n 3 above) para 67.

$F$ (n 3 above) para 73.

$K$ (n 1 above) para 32; $F$ (n 3 above) para 70.

$F$ (n 3 above) para 72 .

$K$ (n 1 above) para 57; $F$ (n 3 above) para 77. 
employer. This close connection renders the respondent liable vicariously to the applicant for the wrongful conduct of the policemen.

The Chief Justice, in the final blow to the Minister's case applies this and finds:

The police vehicle, which was issued to him precisely because he was on standby duty, enabled Mr van Wyk to commit the rape. It enhanced his mobility and enabled him to give a lift to Ms F. Further, when Ms F reentered the vehicle, she understood Mr van Wyk to be a policeman. She made this deduction from the dockets and the police radio in the vehicle. In other words, he was identifiable as a policeman. And, in fact, he was a policeman. Pivotal is the normative component of the connection test. Beyond her subjective trust in Mr van Wyk is the fact that any member of the public and in particular one who requires assistance from the police, is entitled to turn to and to repose trust in a police official. ${ }^{59}$

\subsection{Minority concurring judgment}

The concurring minority judgment of Froneman $\mathrm{J}$ is a bold exercise of judicial activism aimed at holding the state liable on the grounds of direct liability. The central theme of Froneman J's judgment is that the state acts through its functionaries and has no capacity to act independently of them. As such, where a state functionary commits a delict it is as though the state has committed that delict itself. ${ }^{60}$ Froneman $J$ recasts the test in a shrewd way for he both simultaneously employs the extension of vicarious liability that $K$ introduced whilst equally discarding its most problematic aspect, namely the sufficiently close connection test. Froneman J argues that it would be more appropriate for a wrongfulness test to be used as it is also likely that a wrongfulness test will more easily yield an accurate result. ${ }^{61}$ The wrongfulness test focuses on the 'duty not to cause harm to another and its breach'.62

Much like the Chief Justice, I am unwilling to engage in a discussion on the merits of the argument as proposed by Froneman $\mathrm{J}$ as none of the parties raised it before the CC itself. ${ }^{63}$

$F$ (n 3 above) para 81.

$F$ (n 3 above) para 90.

$F$ (n 3 above) paras $89-91$

Ibid.

$F$ (n 3 above) para 83. Suffice it to say that whilst Froneman J's reformulation of the test deals directly with the dissent of Yacoob J and Jafta J (and the judgment of the S(A), the same result can be achieved by utilising the sufficiently close connection test as supplemented by the submission in this article. 


\subsection{Dissenting minority judgment}

The dissenting minority judgment of Yacoob J (Jafta $\mathrm{J}$ concurring) deals specifically with two factors of the $K$ test. First, whether there was a duty that existed (this is done through an examination of what the meaning of standby duty is); and secondly, whether the trust that is placed by $\mathrm{F}$ in Van Wyk is reasonable. ${ }^{64}$ Yacoob $\mathrm{J}$ finds that no vicarious liability can attach to the Minister because he answers both questions in the negative - namely that there was no duty by virtue of Van Wyk being off duty and that F's reliance on Van Wyk was unreasonable.

I will examine each of these factors in turn as a means of critiquing the minority judgment. It is hoped that in the rebuttal offered herein, any Court dealing with a similar matter in future will be able to use the approaches offered to supplement the test and make an appropriate finding of vicarious liability.

\section{The meaning and impact of standby duty}

The response offered in terms of this question deals with the arguments of both Nugent JA in the SCA and Yacoob J in the CC. The reason for dealing with both sets of arguments pertaining to standby duty is owing to the fact that there is a significant degree of overlap between them and in dealing with both sets of arguments, I am of the opinion that this on duty/off duty question is settled more thoroughly.

Nugent JA drew specific attention to the fact that Van Wyk was on standby duty when he raped F. By virtue of this, Nugent JA asserted that Van Wyk was effectively off duty and he had no legal obligation to protect $F$. From this, no vicarious liability could attach to the Minister. The rape was thus committed in his private capacity and had no bearing to his official employment. ${ }^{65}$

Mogoeng $\mathrm{CJ}$ deals with this technical distinction between being on and off duty and the subsequent legal obligations that places on members of our police force by posing the following question: 'Can we say that because a policeman is not on duty, he has no obligation as a policeman to protect a child against rape? I do not think so. ${ }^{66}$ Whilst Mogoeng CJ's answer to the on/off duty question has been canvassed above, I am of the opinion that a far more critical approach needs to be taken to the fact that Van Wyk was neither on duty nor off duty at the time, but rather that he was on standby duty.

$F$ (n 3 above) para 175.

$F$ (n 3 above). Appellant's Heads of Argument para 9.

$F$ (n 3 above) para 67. 
As Mogoeng CJ notes standby duty entitled Van Wyk to the use and enjoyment of a state vehicle and remuneration. ${ }^{67}$ This means that at any time he could be called upon to provide active assistance as and where the case arose. This is either where he may have been placed on duty by his commanding officer ${ }^{68}$ or where he exercised his discretion to do so. ${ }^{69}$ This means that a policeman (whether on or off duty) has an ability to assist any victim of a crime that they are witness to. It is for that purpose that the res ipso facto common law provision exists with respect to policemen; namely, that an off-duty policeman (excluding a reservist) has the ability to place himself on duty in circumstances that warrant it (such as where they are witnessing a crime being committed). They may do this without having to undergo the normal procedures to place themselves on duty (i.e. to get due authority from their commanding officer, to book themselves on air with radio control). This provision speaks to the fact that in a constitutional democracy we can have a legitimate expectation that those in positions of authority/care/trust should exercise the powers of their office when the need arises and where they have the ability to do so. ${ }^{70}$

Accordingly, Van Wyk could not act as a private citizen when he was on standby duty. His status as a private citizen was held in abeyance given that 'at any time of night (he could) have been called upon to attend to any crime-related incident. ${ }^{71}$ This means that he was equally not released from the obligations that attached to him as a policeman on duty. Just as an on duty policeman would have to respond to a crime and be bound by his common law and constitutional duties to protect citizens, so too would a standby duty policeman. ${ }^{72}$

$F$ (n 3 above) para 67

Sec 13(2) of the South African Police Act 68 of 1995 read together with sec 13(1). Ibid. Sec 13(13). Also, Rabie v Minister of Police \& Another 19841 SA 786 (W) 791-F; analogously, the discretionary power given to policemen to effect an arrest in terms of s 40(1)(a) of the Criminal Procedure Act 51 of 1977 as held by $R v$ Bailey 1920 CPD 193, 195 - 196 (as to the technical distinction between on duty/ in uniform when one must exercise that discretion); and Gellman $v$ Minister of Safety and Security 20081 SACR 446 (W) para 94.

70 For the development of the legitimate expectation doctrine see amongst others Administrator, Transvaal $v$ Traub and Others 19894 SA 731 (A). A legitimate expectation is one where there is an express undertaking that a particular process will be used or result will be followed; or that settled conduct is to be expected. With respect to the police, this legitimate expectation arises from various sources (case law, statute, treaties, best international practice, etc). Further, this form of legitimate expectation that the public may have of the police is justiciable irrespective of the source. In this case a legitimate expectation is enhanced by sec 205(3) of the Constitution of the Republic of South Africa when read with sec 2 .

$71 \quad F$ (n 3 above) para 9.

72 While it seems like the Constitutional Court found that as an off duty policeman he would be bound, I opt to keep that question open and limit the discussion to standby duty policeman which is a technically nuanced consideration. 
It is my opinion therefore that if there is any doubt as to whether being on standby duty bears a corollary relationship to being on duty or being off duty, a court would err on the side of caution and align standby duty to being closer to functioning as an on duty policeman. In that way, the Minister will not be able to escape liability for the wrongdoing of his employees even though he enjoys the benefits of their status as not being private citizens. Standby duty policeman cannot be considered on duty when it comes to fighting crime but being off duty when it comes to the State being held liable for their delictual conduct.

This submission deals with the first aspect of Yacoob J's dissent as outlined above. ${ }^{73}$ The learned Justice seems to assert that standby duty policemen are off-duty until they are called upon for active service ${ }^{74}$ It is submitted that their role is to act as a reserve force that may be called upon at any time to assist on duty policemen where circumstances require it. While they are on standby duty, they are still operating under a duty to provide a service and are thus acting under the auspices of the employer's authority. To argue that they are off-duty denies the role they actually play. If they are considered off duty, it undermines Yacoob J's own argument that 'he had to be available to go on duty if called to do so. ${ }^{75}$ Off-duty policemen are under no duty to, within normal circumstances, be available to go on duty whereas standby duty policemen are. ${ }^{76}$

This acknowledgment shows a contradictory train of thought as to how standby duty policemen should be viewed: on one hand Yacoob J says they operate under a duty to act (like on-duty policemen) but on the other he says that they are to be considered off-duty (and thus do not have a duty). Yacoob J's concession shows that standby duty policemen are acting under some duty which distinguishes them from being off-duty. It is preferable, as I argue, that when standby duty policemen commit a delict the state can be held liable so that if a person has their rights infringed by a policeman acting under any duty, they are entitled to some form of recourse.

Yacoob J's finding has the potential effect of putting him at odds with our jurisprudence on cases of this nature. By stating that 'the only question to be determined in this case is whether the circumstances lead to the conclusion that there was a sufficient connection between his wrongful acts and commissions and the business of the employer to render the employer liable ${ }^{, 77}$ he possibly

$F$ (n 3 above) paras 155 - 156

$F$ (n 3 above) para 155 - 156.

$F$ (n 3 above) para 156.

Agreement of the Safety and Security Bargaining Council 2002-05-08 http:// www.sssbc.org.za/ClientFiles/Documents/agreements/2002/Agreement_5.2002_ Working_hours_in_the_SAPS.pdf (accessed 29 April 2013).

$77 \quad F$ (n 3 above) para 156. 
suggests that even where a person may commit unlawful acts during the course and scope of his employment, the employer may escape liability where there is no connection or not a strong enough connection between them. It is submitted that this statement is diametrically opposed to the reasoning of $K$ that Yacoob $J$ happens to quote favourably. ${ }^{78}$ The interests of the employer in cases such as these would never be to rape a person. If the emphasis of the test is the connection between the interests of the employer and the employee it may even render the state not liable where the on-duty policeman commits a delict given the divergence in interest that Yacoob J seems to emphasise. The second leg of the $K$ test must take preference: namely, where there is a sufficiently close connection. ${ }^{79}$

As evidence for the fact that in this case the offence was committed within the course and scope of employment and that there was a sufficiently close link between the delict and interest of the employer, one can rely on the judgment of Yacoob J himself. Whereas it is not evident from the judgment of Mogoeng CJ's as to why the policeman was driving his unmarked police vehicle at that time the delict was commited, Yacoob J's judgment provides further clarity. Van Wyk was on standby duty for a set period and during that time he was performing police work. However, at some stage during the evening, Yacoob $\mathrm{J}$ states 'he stopped performing this function at 20:00' and then went on to improperly use the vehicle to go to a night club. ${ }^{80}$

As illustrated above, being on standby duty means that a policeman is obligated to perform certain functions and that in exchange for this they are adequately remunerated. Yacoob J's seeming acceptance of Van Wyk's unilateral disengagement of his duties as terminating any duty that may have existed and thus exonerating the Minister cannot be accepted. It is submitted that any policeman's subjective feelings/frame of mind at the time that they disengage from their duties does not count. As it was held in Feldman, ${ }^{81}$ the employee disengaging from their duties and committing a delict will not exonerate the employer from liability. Despite Van Wyk's unilateral disengagement he was in fact on standby duty when he committed the rape and accordingly the state should be found liable. An acceptance of the contrary position, that a unilateral disengagement from one's duty is binding, undermines the very command-and-control structure that the police service is premised upon.

$F$ (n 1 above) paras 152 - 154.

$F$ (n 3 above) para 48.

$F$ (n 3 above) para 157.

Feldman (n 35 above). 
The significance here of the duty element when contrasted with other instances of vicarious liability is only too significant. Whereas unilateral disengagement has been accepted by our Courts in instances where the duty arose out of a commercial contract of employment, ${ }^{82}$ our courts have been justifiably unwilling to accept the same with respect to the police given the constitutional obligations enjoining them to serve the people of this country. It is submitted therefore that Van Wyk was under a duty and that by breaching it, provided that a sufficiently close connection was established (as it has been), the Minister should be held liable

\section{$7 \quad$ Was F's trust unreasonable?}

The other aspect of Yacoob J's dissent focuses on whether the trust specifically arising between $\mathrm{F}$ and Van Wyk was reasonable. I am of the opinion that given the acceptance in $K$ that no hard and fast rule could be developed so as to avoid the position that absolute liability would be the result; ${ }^{83}$ such a position warrants a case-by-case analysis of the facts. I shall argue that based on the facts of the case it was and that accordingly, the abuse of the trust perpetrated by Van Wyk, further gives rise to vicarious liability on the part of the Minister.

On the facts of $F$, it is not difficult to draw the conclusion that by virtue of Van Wyk being on standby duty and the Minister vesting in him certain trappings of office (by permitting use of a police vehicle, albeit unmarked, and possession of police dockets), the Minister created the impression that he was a policeman. According to the standard rules of an estoppel defence, borrowing from the law of agency, where such an impression is created by the principal and an innocent third party relies on that impression to their detriment, the principal (in casu, the Minister) will be estopped for denying liability for the conduct of the agent (in casu, the employee policeman). ${ }^{84}$

From the judgment of Mogoeng $\mathrm{CJ},{ }^{85}$ it is possible to infer that he (and the majority of the court) agrees that this kind of justification

See Costa da Oura Restaurant (Pty) Ltd t/a Umdloti Bush Tavern v Reddy 20034 SA 43 (SCA). Even though the High Court saw the assault by the barman Goldie as being directly related to and emanating from his duties as a barman, the SCA was of the opinion that the assault occurred once he has abandoned his duties and thus his act was one of personal gratification that could not be attributable to his employer. Whereas this kind of unilateral disengagement could be accepted in the context of private citizens, it is doubted whether it would apply in the context of a public functionary such as a policeman in light of the constitutional mandate they are given.

$83 \quad F$ (n 3 above) para 84

84 See Monzali v Smith 1929 AD 382; Peri-Urban Areas Board v Estate Breet 19583 738 (T); Dicks v Mutual Fire \& General Insurance 1963 (4) SA 501 (N); Beyleveld v Southern Life 19891496 (A); Glonfico v ABSA Bank t/a United Bank 20026 SA 470 25 (SCA)

F (n 3 above) para 81. 
may exist. In establishing the sufficiently close connection he mentions that $F$ understood that her rapist was a policeman. ${ }^{86} \mathrm{He}$ establishes this by citing the fact that $F$ had noticed the police dockets and the police radio in the car. He establishes that these are obvious indicators that her rapist was a policeman. The argument Mogoeng CJ makes correctly is that where a person is identifiable as a policeman it is reasonable for any person to place trust in that policeman and expect assistance from them in accordance with the degree of care that is to be expected of the police force. ${ }^{87}$ The reliance may especially be induced where the person relying on the representation may be vulnerable. The courts must accordingly do whatever is possible to ensure that where that trust is broken adequate mechanisms are established to restore it. This could apply even where an off-duty policeman were to commit a delict provided there was a sufficiently close link between the employment and the wrongful conduct. 88

Yacoob $\mathrm{J}$ disagrees with this and advances two arguments as to why F's reliance was not reasonable:

(a) The first argument, which is the weaker of the two, is to place emphasis on the fact that the policeman was not on duty ${ }^{89}$ and could not have been easily identified as a policeman. ${ }^{90}$ The first aspect of this approach is already dealt with. The issue of whether or not the policeman was easily identifiable can be dispensed with as follows: is an on-duty plain clothes policeman under any less of an obligation to act in accordance with their duty as a policeman than one in uniform? ${ }^{91}$

The answer must be no. The fact that a policeman does not immediately appear to be a policeman (such as being in uniform) does not lessen the obligations they are under especially when they are under a duty to perform. ${ }^{92}$ The reliance of Yacoob J on the facts of $K$ to distinguish between these two cases is tenuous at best. The police are under a general duty to disclose their status as being policemen and assist members of the community when asked to do so. When $F$ asked the policeman whether he was a policeman, this activated that duty which meant he was then under an obligation to come to her aid. In lying to her and in then subsequently raping her, the policeman in this case breached his state-sanctioned duty to $F$. It is for this reason

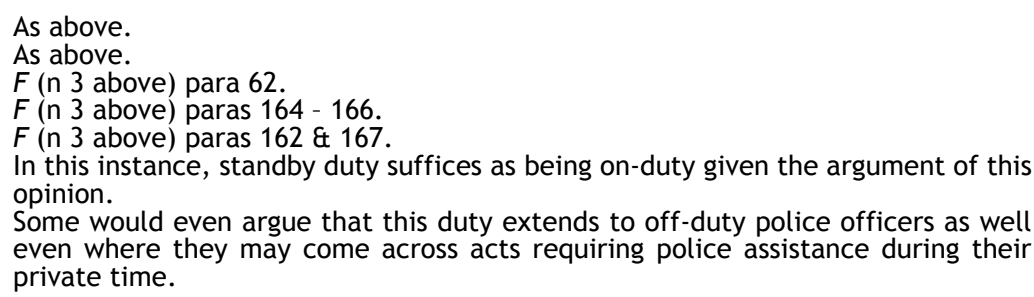

Some would even argue that this duty extends to off-duty police officers as well even where they may come across acts requiring police assistance during their private time. 
that the state is liable. The fact that he was not in uniform or easily identifiable as a policeman is immaterial. ${ }^{93}$ It must be borne in mind however that she drew the conclusion that he was a policeman given she had seen police dockets and a police radio. However, that speaks to reasonableness and is dealt with below.

(b) The second approach of Yacoob $J$ is to focus on the reasonableness of F's conduct in determining whether Van Wyk was a policeman. Yacoob $J$ argues that Van Wyk did not offer a lift to $F$ in his capacity as a policeman and thus offered no official police promise of safe carriage to her. ${ }^{94}$ While it must be conceded that a policeman cannot indemnify anyone to whom he offers a lift a completely safe journey against all forms of harm, it is well within society's remit to expect a policeman not to harm such persons himself. Further, it would not be unreasonable to expect a policeman to fulfil his general duty to protect $F$ against external and intervening factors that would cause $F$ harm where he had the means and ability to protect her.

Further, it does not address the fact that he utilised the property of the state (which was what $F$ based her reasonable deduction that he was a policeman on) to further his own ends. It is submitted that in cases such as these, the 'creation of risk' theory or 'enterprise' theory would serve the purposes of interpreting the vicarious liability test. ${ }^{95}$ This is by virtue of the fact that it was the state's property and employment of the policeman that enabled this policeman to rape $F$, irrespective of how remotely that may have occurred in terms of causation. The fact that he was in possession of and able to use property of the state and was acting under a state mandate brought about by his employment, carries with it a certain degree of authority that can induce any person to place their trust in the possessor/ employee. Mogoeng $\mathrm{CJ}$ does find liability due to these considerations however stops short of affirming that the theory is a legitimate one that can be relied upon in proving a sufficiently close link. ${ }^{96}$ While many may criticise this approach as casting the net too widely and making the employer susceptible to many more instances of liability where they would not normally be held accountable within the framework of the established test for vicarious liability, this is unlikely to occur. ${ }^{97}$ However, the 'creation of risk theory' may indicate which factors, if any, exist at the time that the delict was

$F$ (n 3 above). Applicant's Affidavit paras 26 \& 28.

$F$ (n 3 above) para 169.

Calitz (n 38 above).

$F$ (n 3 above) paras $80-81$.

$F$ (n 3 above) para 84 . It must be noted that despite Calitz's extensive commentary on the use of risk theory as an alternate basis of founding vicarious liability, the decisions of the Constitutional Court and Calitz's own later writings concede that with the decision in $K$, the use of the risk theory in our law is slim. This is even despite the fact that it is used widely in many other jurisdictions in other scenarios. See K Calitz 'The close connection test for vicarious liability' (2007) 18 Stellenbosch Law Review 451. 
committed that would allow a court to better examine the trust aspect that it necessarily gives rise to.

Further, Yacoob $\mathrm{J}$ asserts that in seeing the policeman pursue his own private ends, $\mathrm{F}$ could have never thought him to be on duty and thus any reliance on Van Wyk would be classified as being unreasonable. ${ }^{98}$ This assertion is problematic as it places a burden on a person who may be in a vulnerable position at the time to search for an alternative source of help where a policeman may be present and may be their only chance of getting help. While it can be conceded that gaining assistance from a sober policeman/person is preferable, where there is no alternative avenue of help, it is not unreasonable that help should be sought from a policeman considering the trust that can be placed in them. This is especially the case, as was the situation with $\mathrm{F}$, where they are particularly vulnerable.

However, Yacoob J's determination that F's conduct was unreasonable requires further comment. It would seem that from his criticism of F's election to seek help from the policeman, Yacoob J expected F, a thirteen-year old girl, to behave in a 'reasonable' way that failed to take into consideration the very factors that make this case different. In applying a degree of reasonableness akin to the reasonable man test and in referring strictly to objectively reasonable conduct, Yacoob J incorrectly applied the very thesis of the vicarious liability test: an examination of fact and law that bears in mind both subjective and objective factors to be considered. ${ }^{99}$

Whereas Kruger $v$ Coetzee ${ }^{100}$ developed the traditional reasonable man test and set the applicable objective standard of conduct, ${ }^{101}$ our law has since progressed to include some kind of subjective consideration into the test depending on the facts and circumstances of the scenario at hand. This is owing to the fact that our law recognises that an artificial and objectively set standard of conduct applied indiscriminately could result in disingenuous results. ${ }^{102}$ This is reflected in how professional conduct (in the medical field) is judged differently to the conduct of an ordinary person for example, as per Van Wyk v Lewis. ${ }^{103}$ This is of importance and relevance when questioning whether there is a sufficiently close connection between the delict and the employers interest because these considerations - namely, whether the conduct of the harmed person was reasonable bearing in mind their subjective conditions will yield a just result.

\footnotetext{
$98 \quad F$ (note 3 above) para 170.

99 Rabie (n 40 above).

100 Kruger $v$ Coetzee 19662 SA 428 (A)

101 See eg Herschel v Murpe 19543 SA 464 (A) at 477 and S v Burger 19754 SA 877

1 (A).

102 J Burchell Principles of Criminal Law (2005) 525.

103 Van Wyk v Lewis 1924 AD 438.
} 
In the absence of some form of subjectivisation, academics believe that the test may either result in too strict liability or in liability being escaped altogether. This is a trend in our law that is reflected by developing precedent such as $S \vee V a n A s, 104$ in which our court adapted the test to being about the reasonable man in the position of the accused. ${ }^{105}$ Similarly with $S \vee$ Ngema which held that the test for negligence in our law is still objective but it should be applied according to the standard of the reasonable person of the same background, educational level, culture, sex and race as the accused. ${ }^{106}$ Thus when determining the reasonableness of $F$ 's conduct, it should be evaluated in terms of the reasonable person in the position of F. ${ }^{107}$ Her trust in Van Wyk and whether that created a sufficiently close connection should be evaluated through this scheme as opposed to the removed standard of reasonableness that Yacoob J applied.

Thus when Yacoob J speaks of F's vulnerability, her youth, her biological sex and her fear, ${ }^{108}$ he should instead have evaluated the reasonableness of F's conduct within the confines of those same factors. At the time when this delict was committed, $\mathrm{F}$ a 13 year-old girl child, alone, at night, stranded, potentially under the influence of alcohol, separated from her party that she was with that evening, with no alternative means to gain transport to go home and who was harassed by a person she thought to be a policeman. It is submitted that in light of those factors, F's reliance in the policeman was reasonable. This is bearing in mind that a 13 year-old in those circumstances having seen police dockets in the car as well as the police radio, would have most likely drawn the same conclusion, namely that he was a policeman and that she was deserving of some protection from him - even against his own nefarious intentions.

It is submitted that if Yacoob $\mathrm{J}$ correctly applied the test, he would have found the conduct of a vulnerable and distressed $F$ to be reasonable. The use of reasonable reliance therefore to supplement the thinking within the existing sufficiently close connection test as established by $K$, further limits the true intention of vicarious liability in a constitutional era to be thwarted. In this way, the applicable thinking to the component parts of the existing framework is aligned to the overarching thrust of the test and thus allows for a more congruent result to be attained.

04 S v Van As 19762 SA 291 (A).

105 Own emphasis.

106 S V Ngema 19922 SA 651 (D). This case was to determine the reasonableness of the conduct of the accused with respect to the charge of homicide.

107 While these cases are criminal cases, it must be borne in mind that the law of delict is a civil case and a lower standard of proof applies. Thus, if that is the test for a criminal case with a higher burden of proof, then it should equally apply to 108 the law of delict.

$108 F$ (n 3 above) paras 170 - 172. 


\section{Conclusion}

The critique I offer illustrates how the sufficiently close connection aspect of the course and scope requirement of the vicarious liability test may, despite the authoritative pronouncements of the CC, still result in decisions which shock our collective sense of justice in that upon a technical application, the state may escape liability where one of its functionaries breaches a clear and compulsory duty of protection to a vulnerable person.

It is hoped that by focusing on Yacoob $\mathrm{J}$ and Jafta J's dissent, I have been able to illustrate three further conceptual tools that may be utilised to further supplement and thus enhance the test for vicarious liability as developed in $K$, namely (1) the clarification of standby duty and what it means; (2) the discussion of reasonable reliance and (3) the possibility of utilising the enterprise theory as a means to establish factors which bolster a conclusion of reasonableness all go some way ensuring that, as students, academics and practitioners, we follow the advice of O'Regan $\mathrm{J}$, and guide the courts to:

[T]ake into account the importance of the constitutional role entrusted to the police and the importance of nurturing the confidence and trust in the police, in order to ensure that their role is successfully performed. ${ }^{109}$ 


\title{
UBUNTU IN A POST-APARTHEID SOUTH AFRICAN CONTEXT
}

\author{
By Cornelia van Graan*
}

\section{Introduction}

In this article, I attempt to determine the position and value of ubuntu in the law of post-apartheid South Africa as well as to determine how ubuntu compares to humanitarianism. To achieve this goal, I examine both ubuntu and humanitarianism but I go further than merely an examination of the two concepts in isolation; a determination of the similarities and differences also takes place. The terms to be used in this study will be 'traditional ubuntu', which refers to ubuntu as known and understood by the indigenous people of South Africa, and humanitarianism, as known in the Western civilization.

Ubuntu has a strong traditional meaning and forms part of the indigenous law. Prior to 1994, it played no role in South African jurisprudence. During the transition period from apartheid to a nonracial constitutional democracy, South Africa saw many changes and under this new democratic and constitutional dispensation, the law had to change and adapt to provide for and protect people of all cultures in South Africa. In an effort to extend the law to all people, irrespective of race and culture, the newly-established Constitutional Court moved to include ubuntu into South African law and jurisprudence as a legal value. ${ }^{1}$

Now the questions which need to be addressed are: what exactly is ubuntu? How does ubuntu differ from humanitarianism? What is the effect of the distinction between ubuntu and humanitarianism on the use of ubuntu in South African law? To answer these questions I examine an array of materials including the interim Constitution, ${ }^{2}$ the 1996 Constitution, ${ }^{3}$ case law and writings on ubuntu by the most prominent writers on the subject.

* LLB (UP); LLM (Research) candidate in Criminal Law, University of Pretoria; Admitted Advocate of the High Court of South Africa.

See S v Makwanyane 19956 SA 391 (CC) and PE Municipality v Various Occupiers

20051 SA 217 (CC) where the court interprets and discusses ubuntu.

2 The interim Constitution of the Republic of South Africa, Act 200 of 1993 ('The interim Constitution').

3 The Constitution of the Republic of South Africa, 1996 ('The Constitution'). 
Before I commence the discussion on ubuntu and its application in the South African context, I will attempt to define ubuntu, with reference to the traditional meaning, after which I will define humanitarianism. ${ }^{4}$ This is done to provide the reader with a clear understanding of the aforementioned concepts.

\section{Ubuntu: Traditional or Cultural definition}

Traditionally ubuntu has been defined as 'umuntu ngumuntu ngabantu, motho ke motho ka batho ba bangwe, 5 which in English translates to 'I am a human being through other human beings' 6 In essence, this means that an individual exists because of the community and not in spite of it. Thus the community forms just as much a part of the individual as the individual forms part of it. ubuntu, in its most basic form, is a philosophy of life and law which holds the individual and the community responsible for the well-being of both the community and the individual. Central to this philosophy of life and law is personhood, humanity, morality and dignity. ${ }^{7}$ It is an approach to jurisprudence and philosophy which is opposed to individual actions which are harmful to the community as a whole. ${ }^{8}$ The needs of the whole community are held to be more important than the needs of the individual. ${ }^{9}$

When the definition of ubuntu is examined, certain questions arise: what is the impact of this approach to life and law on the individual? What about the rights of the individual? Does the individual lose his existence and his rights? Can an individual be simultaneously independent and dependent? Does this approach lead to the individual suffering when the community suffers even though he might have the resources not to suffer? What is the implication for the existence of the individual? Does the individual lose his identity to obtain a communal identity? These are difficult questions to answer but I believe that they can be answered with reference to the definition of ubuntu, and a proper understanding and application of ubuntu.

Before I attempt to answer these questions, I will first discuss humanitarianism as an alternative to the traditional understanding of ubuntu.

$4 \quad$ With this I mean a definition that has developed and is developing in line with the Constitution and the new South African legal position also referred to as the western definition or humanitarianism.

5 Y Mokgoro 'Ubuntu and the law in South Africa' in D Cornell \& N Muvangua (eds) Law in the ubuntu of South Africa (2011) 363. Future page references refer to the draft manuscript on file with the author.

6 Mokgoro (n 5 above) 363.

7 NL Maho “O se re homorwa “morwatowe!” African jurisprudence exhumed' (2010) CILSA XLIII 326.a

Mokgoro (n 5 above) 364-365.

$9 \quad$ Mahao (n 7 above) 325. 


\section{Humanitarianism ${ }^{10}$}

What can be seen as the 'Western' version of ubuntu amounts to an approach to life and law often referred to as humanitarianism. Humanitarianism is defined as actions and procedures undertaken while treating people with dignity, respect and equality irrespective of their social status or status in a country. Humanitarianism includes any actions and procedures that place the well-being of humans as its first priority. Humanitarianism is a "concern with the condition of a man considered solely as a human being regardless of his value as a military, political, professional or other unit'. ${ }^{11}$ This approach is fitting for a Western society as it is based on equality, dignity and respect but still aims to keep the individual central to the concept. The protection of individual rights is central to the concept of humanitarianism, but is held in such a manner that it is not harmful to the group or community as a whole. The concept entails that individual rights are important but may be limited to ensure the promotion of the 'greater good'.

\section{Comparison between ubuntu and humanitarianism}

When comparing the two concepts, it is clear that in certain respects they do resemble each other, as both of these concepts in essence frown upon individual actions which have a negative effect on the community as a whole. Further, both concepts are based on the principles of equality dignity and freedom ${ }^{12}$ and encourage actions which advance the community and requires of an individual to develop his or her potential in such a way that there is harmony between the individual and the community.

However, it is clear that even though there are strong resemblances between ubuntu and humanitarianism, they can never

'Humanisme' (humanism) is defined in the Nasionale Afrikaanse woordeboek (National Afrikaans Dictionary) (6th edition) as: 'enige beskouing wat die menslike welsyn vooropstel. Dit is ' $n$ mensliewende beweging' ('any view that places the well-being of humans as its first priority. It is a human-centred movement') (own translation).

11 K Mackintosh 'The principles of humanitarian action in International humanitarian law' (Study 4 in: The politics of principle: the principles of humanitarian action in practice) (2000) (HPG Report 5 March 2000) as contained on http:// www.odi.org.uk/resources/docs/305.pdf (accessed 29 September 2012). CBN Gade 'Historical development of the written discourses on ubuntu' (2011) 3 SA Journal of Philosophy 303-304.

12 Gade (n 11 above) 303-304; T Bekker 'Re-emergence of ubuntu: a critical analysis' in D Cornell \& N Muvangua (n 5 above) 490-491.

13 Mahao (n 7 above) 327. 
be equated ${ }^{14}$ as these concepts differ fundamentally from each other in the sense that, although humanitarianism requires humane actions towards each other, as a Western concept it is still firmly grounded on the importance of the individual, whereas the concept of ubuntu is rooted in community and the wellbeing of the community and deals with 'human centeredness'. ${ }^{15}$

Further, a concern with the potential of the individual, the potential of human beings ${ }^{16}$ and thus the potential of the community forms an integral part of ubuntu, whereas humanitarianism does not deal with the concept of the potential of people - an element which bears great importance within the concept of ubuntu. ${ }^{17}$ Furthermore, humanitarianism only requires equal, just and humane treatment of people and therefore does not deal directly with the community or the needs of the community. Even though humanitarianism and ubuntu are based on some of the same values, they are not one and the same as humanitarianism holds the individual at its centre and ubuntu holds the community at its centre.

After examining both the resemblances and the differences between ubuntu and humanitarianism, it is clear that the concept of ubuntu is the more fitting concept for a post-apartheid South African jurisprudence as it fits into the communal way of living still present and dominant in South Africa.

\section{Ubuntu: existence and rights of the individual}

I will briefly revisit the questions raised above concerning the individual when applying ubuntu. What happens to the identity of the individual? Should the individual suffer because the rest of the community suffers even though he might own the resources not to suffer? Does the individual still have his or her own individual rights or are individual rights sacrificed for the good of the community? What about the individual's freedom of choice to live as he or she pleases?

After a proper examination of ubuntu and a comparison thereof with humanitarianism, it is clear that some of the answers to these questions do seem fair. What happens to the individual's identity? The individual retains his identity but his identity is shaped with reference to the community he forms part of, in other words identity is developed through a set of collective ideals. ${ }^{18}$ The same applies to individual morality. The individual remains individual and maintains

14 Y Mokgoro \& S Woolman 'Where dignity ends and ubuntu begins: An amplification of, as well as identification of a tension in, Drucilla Cornell's thoughts' (2010) SAPL 400.

15 Mahao (n 7 above) 319

Mokgoro (n 5 above) 364-365.

As above.

Mokgoro (n 5 above) 364-365. 
the ability to perform his own tasks and live for himself; but his morality is formed through collective ideals and this causes him to act in a manner which is not harmful to the community.

As to the questions regarding individual rights, individual rights exist and are enforceable. This allows the individual to claim infringement upon these rights and he may enforce and enjoy his rights as he deems fit. However, when exercising these rights negatively influences the community, his rights may be limited for the good of the community. Such a limitation is also echoed in section 36 of the Constitution. ${ }^{19}$

Should a person who has the resources not to suffer, especially during harsh times, suffer if the community suffers? The answer seems to be that ubuntu does not expect the individual to suffer with the community but does expect of the individual to use the resources he has available to lessen the suffering of the community. In other words: that which is expected when applying ubuntu is not that we suffer together but that we alleviate pain and suffering through our actions. In that scenario, ubuntu would expect the individual to curb his desires to the advantage of the community. It is therefore clear that contrary to how it appeared at the onset of this study, ubuntu does not lead to nor does it intend the disappearance of the individual. Ubuntu thus envisions an individual capable of humanness and caring, an individual who meets the requirements as set by the community and who strives to fulfil those requirements.

The above mentioned questions, statements and definitions lead to the question of how ubuntu has been entrenched in the interim and the final Constitution by the legislature and the courts and how ubuntu has influenced jurisprudence and legal discourse in South Africa. I will start the discussion with reference to the interim Constitution, and then move on to the 'final' Constitution and certain case law.

\section{A bit of history}

South Africa was a country in turmoil and conflict because black citizens were oppressed by a white government and Western-type law. Apartheid was in full swing and the country experienced unrest. Negotiations between the ruling white party, the apartheid

19 Sec 36(1) of the Constitution states that:

'a right in the Bill of rights may be limited by a law of general application to the extent that the limitation is reasonable and justifiable in an open and democratic society based on human dignity, equality and freedom taking into account all relevant factors including: (a) The nature of the right; (b) The importance of the purpose of the limitation; (c) The nature and extent of the limitation; (d) The relation between the limitation and its purpose; (e) Less restrictive means to achieve the purpose.' 
government and representatives of the black community started taking place yet this did not to relieve the tension in the country. ${ }^{20}$ After lengthy negotiations and conflict, an agreement was finally reached. This agreement brought the interim Constitution into being and formed the basis of a 'new' South Africa based on the values of equality, human dignity, freedom and ubuntu. ${ }^{21}$

\section{Ubuntu and the interim Constitution}

In the interim Constitution of South Africa, ${ }^{22}$ ubuntu was, for the first time, incorporated into South African law when it was expressly mentioned in the epilogue. This created the hope that the legislature had finally moved away from purely imposing Western laws and ideals on an African society. ${ }^{23}$ This change would consequently apply African values to an African society thus generating and allowing 'African solutions to African problems'. 24

The express reference to ubuntu in the interim Constitution created hope of an equal and just society which does not discriminate between people on the ground of their culture, race, gender or religious beliefs. The entrenchment of ubuntu, an African value, into the interim Constitution made it seem as if South Africa was finally a place for all South Africans.

The inclusion of ubuntu in the interim Constitution was significant as it was the first reference to be made to ubuntu in South Africa's legal history, and the first time that the legislators paid due regard to that which is inherently African. Some of the first cases which were decided by the Constitutional Court were decided under the interim Constitution incorporating the concept of ubuntu.

However, although ubuntu was included in the interim Constitution ${ }^{25}$ and used as a tool to decide constitutional cases, ${ }^{26}$ it

20 M Sanders Complicities: The intellectual and apartheid (2002) 1-3, P Waldmeir Anatomy of a miracle: The end of Apartheid and the birth of the new South Africa (2001) 5 - 39, 59 - 237.

21 In Azanian Peoples Organisation (AZAPO) v President of the Republic South Africa 19968 BCLR 1015 (CC), the Constitutional Court recognised the constitutional status of the epilogue containing the concept of ubuntu.

22 See specifically the epilogue of the interim Constitution, Act 200 of 1993.

23 Mokgoro (n 5 above) 364-366.

24 M Goldmann 'Sierra Leone: African solutions to African problems?' (2005) 9 Max Planck Yearbook of United Nations Law 457-515. The phrase 'African solutions to African problems', which dates from the time when African states received independence, became widespread in the aftermath of the 1994 genocide in Rwanda when many Africans shared the feeling that they were better off if they found ways to tackle their problems themselves instead of relying on the United Nations and the Western world.

$25 \mathrm{Sec} 31$ of the interim Constitution provided for the freedom of every person to participate in the culture of their choice.

26 Makwanyane (n 1 above); PE Municipality (n 1 above). 
was not defined or accepted as a Constitutional value. ${ }^{27}$ The courts applied ubuntu as a constitutional value equal to other constitutional values ${ }^{28}$ but the legislature neglected to define ubuntu as a constitutional value. Each court must therefore apply the concept as it sees fit. ${ }^{29}$

\section{Ubuntu and the 1996 Constitution}

The failure to carry the concept of ubuntu over to the 1996 Constitution left a lot of South Africans legal scholars with the question why ubuntu was not carried over? ${ }^{30}$ Further, it also left open the question whether or not the legislature still deemed ubuntu as an important part of South African law and as a constitutional concept. It begs the question: why has ubuntu not been given a concrete definition in South African law and what meaning have the South African courts given to ubuntu? How, if at all, did the courts apply ubuntu to the law in South Africa? Further, what effect did the courts' interpretation and treatment of ubuntu have on the concept of ubuntu in South African law? To answer these questions, a critical approach has to be applied when examining the legislation and the judgements of the Constitutional Court.

During this assessment certain uncomfortable questions will have to be asked - questions such as whether the exclusion of ubuntu from the 1996 Constitution was caused by oversight or was it something more sinister such as deliberately leaving ubuntu out of the Constitution to 'de-Africanise' the 1996 Constitution? To answer these questions I refer to prominent case law, legislation and prominent writers on the topic of ubuntu.

I start my search for answers to these questions by examining the text, spirit and purport of the 1996 Constitution. When examining the epilogue, together with sections $17,9,10,11,12,14$ and 39 of the Constitution, it is clear that the values of human dignity, equality, life, privacy and freedom are clearly entrenched and that the courts, when interpreting any legislation or State action, are bound to respect these values. These sections from the Constitution clearly resemble some of the values of ubuntu as they are discussed in the paragraph on the definition of ubuntu.

Therefore, it appears to me that the legislature did not deem it necessary to expressly mention and entrench ubuntu as it would have

The Constitution does not define ubuntu.

$\mathrm{K}$ van Marle \& D Cornell 'Exploring ubuntu: Tentative reflections' in D Cornell \& $N$ Muvangua (eds) Ubuntu in the law of South Africa (2011) 452-477. 
been redundant and repetitive, as the relevant sections of the Constitution already entrench and enforce the core values of ubuntu. These values are, however, expressed in different terminology.

With reference to the principle of communality which forms part of ubuntu, I examined section 36 of the Constitution. This section is commonly known as the limitation clause as it limits the rights and freedoms of the individual, to protect other individuals and the society from misuse and abuse of freedoms and rights.

This section was not specifically written and entrenched to serve the community, but it can be interpreted and applied in such a manner that it can sometimes serve the purpose of protecting the community from individual actions which are harmful to the community. It is herein that the resemblance of section 36 and the communal aspect of ubuntu is to be found. This section cannot be equated to the communal aspect of ubuntu, but it can serve as an explanation as to why constitutional writers or the legislature did not deem it necessary to specifically mention ubuntu in the final Constitution. Section 38 determines who has locus standi in certain actions while it also determines that an individual can act on behalf of a community and therefore this section serves as an example of how the community is protected under the Constitution. ${ }^{31}$ Furthermore, it also enforces and emphasises the communal value contained in ubuntu.

After the examination of these sections I am of the opinion that although there is not an explicit reference to ubuntu in the Constitution, the principles of ubuntu is entrenched in the Constitution. All that is needed to make ubuntu part of South African law is a little creative thinking and persistence on the part of the jurist when interpreting the Constitution. When I say this I do not mean that 'ubuntu should mean anything to any man'. 32

The interpretation of the Constitution provides for the use and interpretation of indigenous law during legal disputes. ${ }^{33}$ Therefore indigenous law, which includes the concept of ubuntu can be implemented in line with already existing law. It is during legal disputes that a jurist must research the concept of ubuntu, interpret and present ubuntu as a viable concept to the courts. Thereafter, the courts should pay due regard to the concept of ubuntu and the interpretations of ubuntu that were presented to court. approach a competent court, alleging that a right in the bill of rights has been infringed or threatened. These include (1) Anyone acting in own interest (38(a)) (2) Anyone acting as a member of, or in the interest of, a group or class of persons (38(c)) and (3) Anyone acting in public interest (38(d)).

33 Bekker (n 12 above) 491.

33 Sec 39 of the Constitution. 
Ubuntu should truly be considered and not just used and referenced as an afterthought. The best chance of survival ubuntu has is if the concept of ubuntu is judicially defined. Thus, in answer to the questions stated above, in my opinion the express reference to ubuntu was not carried over from the interim Constitution to the 1996 Constitution because the writers of the Constitution did not deem it necessary to expressly entrench ubuntu as a constitutional value as there are other values in the Constitution which resemble the values expressed by the concept of ubuntu. Call it negligent and inconsiderate at most but at least the removal does not, in my opinion, amount to anything sinister such as the 'de-Africanisation' suggested by some writers. ${ }^{34}$

\section{Case law: Facts and decisions}

In this section of the discussion I will start with references to case law and the references to the Constitution in the case law. In each case, I will first give a short overview of the facts, then the relevant provisions of the Constitution surrounding the case and lastly I will discuss the application of ubuntu. For ease of reading, the discussion is divided into two parts: first a discussion of cases decided under the interim Constitution and then cases decided under the 1996 Constitution.

\subsection{The interim Constitution}

One of the most important cases and certainly one of the most influential in South African law is $S v$ Makwanayane. ${ }^{35}$ I examine this case not for its importance in criminal law but because it is the first case in which the judges explicitly referred to ubuntu. This case, reported in 1995, was one of the first cases heard by the South African Constitutional Court.

The case was heard under the interim Constitution and thus under the Constitution which recognised ubuntu. In short, the facts of the case are as follows: Makwanyane and his accomplices were prosecuted and found guilty on multiple counts of murder, attempted murder and robbery with aggravating circumstances. The court a quo imposed the death penalty on Makwanyane and the other defendants. Makwanyane appealed against the decision of the court but the appeal was dismissed and the death penalty retained. The appeal process continued until the case reached the Constitutional Court.

E Moosa 'Tensions in legal and religious values in the 1996 South African Constitution' in M Mamdani (ed) Beyond rights talk and culture talk: Comparative essays on the politics of rights and culture (2000) 131. See also Van Marle \& Cornell (n 30 above) 464.

35 S v Makwanayane \& Others 19956 BCLR 665 (CC). 
The appeal was based on the grounds that the death penalty infringed the defendant's right to life and dignity as set out in sections 10 and 11 of the Constitution 36 and that the death penalty constituted punishment which is 'cruel and inhuman' and that under the new constitutional disposition no person may be subjected to 'cruel, inhuman or degrading' punishment. ${ }^{37}$ Thus the issue for consideration in the case was the constitutionality of the death penalty and whether or not it infringes the constitutional rights of the accused. ${ }^{38}$

Accordingly, the court considered the appeal and the death penalty was abolished by the majority of the court. Although Sachs J formed part of the majority abolishing the death penalty, he delivered his own separate judgment expressing certain concerns regarding ubuntu as a constitutional value. Sachs J discussed the question regarding the use of ubuntu in great detail, asking questions such as why ubuntu was not brought before the court for argument and how ubuntu should be interpreted. He goes on to give an explanation of how he believes ubuntu can be used in legal disputes. Further Justice Sachs showed a concern with the sources of South African law and indicated that African (indigenous) law should be used as a source of law yet he failed to give concrete meaning to the concept of ubuntu and how it should or could be developed in South African law. Ubuntu thus remains an unclear concept.

Apart from expressing a concern about African and indigenous law not being considered and developed under the interim Constitution, the judgment does not contribute to the entrenchment or development of ubuntu as part of South African law.

The manner in which the judgment reads and the manner in which ubuntu was discussed by Constitutional Court judges makes it seem as if the judgment had a political character. ${ }^{39}$ Confusion remains regarding the Constitutional Court interpretation of ubuntu as a necessary legal principle to be considered when deciding cases. A person examining ubuntu may, with reason, wonder what value ubuntu has for South African law if the Constitutional Court although considering ubuntu properly fails to give concrete meaning and application to ubuntu as a constitutional value.

In my opinion, the effect goes much further than anticipated. I stated earlier that I do not think and cannot imagine that the drafters of the Constitution deliberately left the concept of ubuntu out of the 1996 Constitution with the purpose of de-Africanising the Constitution has the right to life'.

37 Sec 12(1)(a)-(e) of the Constitution contains the right to freedom and security of the person.

38 Sec 10 of the Constitution: everyone has inherent dignity and the right to have

their dignity protected and respected.

39 Bekker (n 12 above) 491-492. 
nor do I think it was an oversight. After examining the Constitutional Court's decision under the interim Constitution and the little regard they had for the principle of ubuntu while it was entrenched in the epilogue of the interim Constitution, it is my opinion that it may be possible that the drafters removed the term ubuntu from the Constitution and entrenched the principles associated with ubuntu in other sections of the Constitution as they did not deem it necessary to entrench the concept of ubuntu into the Constitution.

\subsection{The 1996 Constitution}

One of the most important cases heard under the 1996 Constitution is that of Port Elizabeth Municipality $v$ Various Occupiers (PE Municipality) ${ }^{40}$ as it deals with the rights of people to housing and land occupation. The facts in short are that some squatters occupied a piece of privately owned land. The Port Elizabeth municipality applied for an eviction order against the squatters. The municipality argued that they were allowed to evict the squatters as the squatters were unlawfully occupying the land. Furthermore, the municipality argued that they were not obliged to provide the squatters with alternative housing. The squatters, on the other hand, argued that the municipality arbitrarily evicted them from the land and did not comply with the relevant legislation required when a person, institution or company intends to evict squatters from the land. The squatters furthermore argued that due to the municipality's noncompliance with the relevant legislation, ${ }^{41}$ the municipality acted in a way that was inconsistent with the Constitution ${ }^{42}$ and unfair, so that its actions were constitutionally reviewable. The squatters also argued that there was an obligation on the municipality to provide them with alternative housing.

The court $a$ quo held that there was no duty on the municipality to provide the squatters with alternative housing before evicting them and therefore the court granted the eviction order. Thereafter, the squatters approached the Supreme Court of Appeal which set aside the eviction order and held that the municipality was obliged to provide the squatters with alternative housing.

Thereafter the municipality applied to the Constitutional Court for leave to appeal, the restoration of the eviction order and an order setting out that the municipality was not obligated to provide

200412 BCLR 1268 (CC).

41 The Prevention of Illegal Eviction from and Unlawful Occupation of Land Act 19 of 1998 (PIE Act).

42 Sec 26(3) of the Constitution states that 'no one may be evicted from their home, or have their home demolished, without an order of Court made after considering all relevant circumstances'. 
alternative housing when evicting unlawful occupiers. ${ }^{43}$ The Constitutional Court denied the municipality's appeal and held that the municipality had to comply with all relevant legislation. Therefore, there was a duty on the municipality to participate in mediation procedures with the occupiers it aimed to evict from the land in order to provide alternative housing to the occupiers.

The Constitutional Court accordingly found that the municipality acted in an arbitrary manner and that the municipality's actions infringed the right to housing and other Constitutional rights of the squatters. It is interesting to see that in the Port Elizabeth Municipality case, Sachs J invoked ubuntu. Sachs J delivered the judgment in this case and he once again referred to ubuntu when he interpreted the Constitution including the right to housing ${ }^{44}$ and the right to private property. ${ }^{45}$ This reference to ubuntu had the effect that the squatters' right to housing as well as the right to own private property had to be taken into account when determining the legality of an eviction notice, as well as the responsibility of the state to provide housing to the squatters.

In South African law, each case has to be decided on its own merit, taking all relevant circumstances into account, as it is the only way to achieve results which are fair, equal and reasonable in a new and democratic South Africa. In this case the court held that, in accordance with ubuntu, the state has a responsibility toward the squatters and that the state has a duty to protect the poor and vulnerable groups of society. Further, Sachs J held that PIE Act must be interpreted in accordance with the values of the Constitution and the communitarian attitude encapsulated in the concept of ubuntu. From this judgment, it is clear that both sections 25 and 26 of the Constitution as well as the PIE Act are informed by ubuntu. Further, the judgment makes it clear that when considering socio-economic rights, the concerns of the community as a whole should be safeguarded and taken into account. This is nothing other than expressing a value of ubuntu in plain English. Did the court give an express meaning or at least a more concrete meaning and interpretation of ubuntu?

To answer this question I have to compare the PE Municipality case with the Makwanyane case. When comparing these two cases concerning the application of ubuntu in South Africa, it is clear that

PE Municipality (n 1 above).

Sec 26 provides that everyone has the right to have access to adequate housing and further in sec 26(2) that 'the state must take reasonable legislative and other measures, within its available resources, to achieve progressive realisation of this right'. Sec 26(3) adds that 'no one may be evicted from their home, or have their home demolished, without an order from the court made after considering all relevant circumstances.'

45 Sec 25(1) stipulates that 'no law may permit arbitrary deprivation of property'. 
some progression has been made in the use of ubuntu during legal proceedings and when the protection of fundamental rights are at issue. The progression lies in the fact that while ubuntu was entrenched in the interim Constitution and reference was made to ubuntu in the Makwanyane decision regarding the death penalty, ubuntu was not entrenched under the 1996 Constitution, and yet still the majority judgment in PE Municipality case decided by Sachs J unambiguously referred to the concept of ubuntu.

\section{Conclusion}

I have now discussed the most relevant material and will now attempt to answer the questions as stated throughout the article. Is there another more universal term which can replace ubuntu? The short answer is no, because ubuntu is a traditional and uniquely African concept. Other concepts might come close and may resemble ubuntu but they are not the same.

I examined both the concept of ubuntu and humanitarianism and thereafter compared the two concepts with each other. Through the comparison it was clear that the two concepts, while reflecting and promoting some of the same principles, differ substantially in other respects. It is clear that humanitarianism, a Western concept, still holds the individual central to the philosophy of the concept while ubuntu has at its centre the community.

When dealing with humanitarianism it is clear that the community's welfare is important and the concept does promote communal values, but the concept promotes these values because the welfare of the community enhances the welfare of the individual. Humanitarianism, just as ubuntu, has as its core philosophy that people should be treated humanely and with dignity and respect but it differs from ubuntu in the sense that humanitarianism places an emphasis on the individual while ubuntu requires that we move away from the individual and place society as a whole at the centre of our law and way of life.

The question whether or not ubuntu removes the individual's identity has already been dealt with but I will briefly repeat that the individual is not stripped of his individual identity. The individual is challenged to form and create his identity in a way that it is in accordance with the values of the community and to develop an identity, lifestyle and life orientation which does not damage the community but which promotes and advances the community. Ubuntu is not based on the belief in suffering together. In other words, it does not mean giving up your resources for the community so that, when the community suffers, every individual, even the individual who does not need to, suffers. Ubuntu, after close examination and extensive research, seems to have as its purpose that an individual who has the 
resources to take care of himself and the community should and may do so. Ubuntu does not expect of the individual to give up all his rights but it does expect the individual to act in a manner which is to the advantage of the community. Ubuntu also expects an individual to curb his desires if his desires affect the community negatively. It is clear that ubuntu is a philosophy of life and law which holds the promotion of the group central but it does not expect the impossible or the unreasonable from the individual. Ubuntu does not expect the individual to suffer because the group is suffering but ubuntu does expect the individual to use his resources in such a way that the resource promotes the group or community and not the individual.

However, care must be taken so as not to turn the ideal of ubuntu into a reality that has a part of society carry the burdens of the rest of society. Ubuntu must be applied in a manner which promotes unity in the community without creating dependence of one group in society on another group in society. Ubuntu should remain a concept where the focus is on respect, dignity and the welfare of the community because communities, irrespective of race, gender or ethical orientation, are dependent on each other. There can be no talk of ubuntu or a true post-apartheid South Africa before the different communities in our society start taking care of or at least start considering each other. For ubuntu to be a viable concept, it must not just be developed in law, the concept must be made part of everyday language and everyday living. Only after we have made the values of ubuntu part of our everyday lives and we again begin taking care of each other and our communities then can we truly start to entrench ubuntu in our law.

As to the question of whether or not ubuntu should be entrenched into South African law I am of the opinion that the Constitution provides for the protection of the core values of ubuntu. Although it would have been satisfying to see an explicit reference to ubuntu in the 1996 Constitution the fact that there is no such explicit reference to ubuntu in the Constitution does not prevent ubuntu from being part of South African law. The Constitution allows the writing of legislation promoting and protecting the Constitutional values, therefore ubuntu can become part of South African law through such legislation. The focus must, in my opinion, be on the development of ubuntu as a national concept before entrenching the concept in legislation.

In this article, I only examined two cases; there are other cases which can also be examined. I chose the two cases because they illustrate the point I was trying to make most effectively. The examination of Makwanyane clearly illustrates the regard that the Constitutional Court has for the concept of ubuntu and indigenous law and the case establishes a starting point for the development of ubuntu. 
Therefore, it does not come as a surprise that the reference to ubuntu was not carried over to the 1996 Constitution. I considered the possibility that the reference to ubuntu was left out as an attempt to de-Africanise the 1996 Constitution and in that way limit the legal sources to those already accepted as legal sources in South African law. However after an examination of both Constitutions and the two cases heard under the interim Constitution and the 1996 Constitution respectively, it is clear that this was not the case and that the Constitutional Court built on the previous decisions of the court and is starting to refer to ubuntu more readily.

In the PE Municipality case, the Constitutional Court accepted the concept of ubuntu and started to develop the concept. The court started the application of ubuntu on the basis which was laid by $S v$ Makwanyane and gave as much, if not more, consideration to the influence of ubuntu on the South African law. This development took place even though ubuntu was not entrenched in the 1996 Constitution. In the PE Municipality case, the Court, even though the Constitution did not entrench ubuntu, was prepared to develop ubuntu as the court had a previous judgment to support the development and other sections of the Constitution resemble the principles of ubuntu. Whichever reason it may be, the move away from only applying those sources already accepted as sources of law to applying sources that are unique to Africa is a long-awaited shift.

When examining the writings on the topic of ubuntu it is clear that there is a lot of positive and negative critique on the subject, especially on the Constitutional Court judgments. Critique included the idea that Sachs J's judgment in Makwanyane is incomplete and that there was no concrete definition or application of ubuntu in the judgment, ${ }^{46}$ and this critique is understandable. When I started my research on the topic I held the exact same critique. I am still of the opinion that it is necessary to define, or rather redefine, the concept of ubuntu. I hold this opinion because as ubuntu stands now it has a strong cultural meaning which fits an African culture. It is also a concept which Western cultures do not understand and cannot comprehend because, even though they have concepts similar to that of ubuntu, it is not exactly the same as that of ubuntu since their cultures are based on individualism and not communitarianism.

Therefore I am of the opinion that before ubuntu can be reintegrated into a South African society it must be redefined. I realise that defining and redefining ubuntu is not as easy as it may appear. Defining ubuntu in plain English alone is a nearly impossible feat as it cannot be separated from the cultural connection it has. This is experienced as a problem by the majority of the writers on the subject but I came to realise that keeping the definition of ubuntu 
connected with its cultural contexts might be an ideal way to deal with ubuntu. ${ }^{47}$ I suggest that instead of translating ubuntu into English and trying to explain the cultural connection but failing to do so, legal scholars should consider moving away from translation and definitions of words and concepts and should aim to transform society and culture from a society and culture which is separated and distant from each other to a society that takes care of each other and shares a mutual respect and responsibility for each other. In other words, the community will have to be socially and culturally redefined.

How we, as society, achieve social and cultural redefinition and thus how we then redefine ubuntu, depends on how our courts and legislature interpret the Constitution in relation to ubuntu and on how we, as citizens and legal scholars, interpret and allow others to interpret the Constitution and ubuntu. I am of the opinion that after society has been transformed into a community based on respect and equality then only will we be able to obtain a universal and social definition of ubuntu.

To conclude, I am of the opinion that to define or redefine ubuntu, it is important to redefine our society and our identity as South Africa. I caution against Westernising an African concept and Africanising a Western concept and advocate for a merger of the concepts of ubuntu and humanitarianism to create a concept unique to South Africa which finds a midway between humanitarianism and ubuntu. The approach must recognise that in some situations the community must get preference and in other situations the individual should get preference. Thus, I suggest that, when ubuntu and humanitarianism is merged, ubuntu as currently defined to mean 'I am a human being through other human beings' will be extended. ${ }^{48}$ । therefore suggest that, by taking social context into account, the new concept may result in ubuntu being understood as 'I am a person through other people yet in some reasonable circumstances the needs and right of the individual will receive preference above that of the community'.

$47 \quad \mathrm{~N}$ Bohler-Müller 'Some thoughts on the ubuntu Jurisprudence of the Constitutional Court' in Cornell \& Muvangu (n 31 above) 486- 488, Bekker (n 12 above) 491-493. 48 Mokgoro (n 5 above) 363. 


\title{
VOETSTOOTS TER UITSLUITING VAN AANSPREEKLIKHEID
}

\author{
By Johannes Jacobus van der Walt*
}

\section{$1 \quad$ Inleiding}

Soos die titel van hierdie artikel aandui, beïnvloed 'n voetstootsklousule kontraktuele aanspreeklikheid en sluit dit die werking van kontraktuele remedies uit.

Daar moet vanuit die staanspoor onderskei word tussen ex lege waarborge (naturalia) en ex consensu waarborge (incidentalia). Die rede hiervoor is dat die voetstootsklousule nie laasgenoemde waarborge kan uitsluit nie. Verder, indien die voetstootsklousule wel ingesluit word en die ex lege waarborg word uitgesluit, laat dit die koper sonder die aedilisiese aksies. ${ }^{1}$

In die Suid-Afrikaanse handelswêreld is daar sekere gevestigde grondbeginsels met spesifieke juridiese waarde en belang. Twee belangrike voorbeelde van hierdie grondbeginsels - pacta sunt servanda en die rol van goeie trou - vind toepassing in hierdie artikel. Kontraktuele verhoudings is geleë in die hart van die handelswêreld, daarom moet daar gestand gedoen word aan die inhoud van kontrakte. Goeie trou, alhoewel dit direk teenoor pacta sunt servanda staan, moet egter ook in ag geneem word vanweë die gemeenregtelike waarde van hierdie beginsel en ook nou die grondwetlike belang daarvan wat deur die saak van Barkhuizen $v$ Napier $^{2}$ bewerkstellig is. Met inagname van genoemde twee beginsels word die verband tussen die voetstootsklousule en dolus in die lig van Appèlhof beslissings bevraagteken waar die hof die onus wat deur die koper gedra word onnodig, en met respek verkeerdelik, ten gunste van die verkoper uitgelê het. ${ }^{3}$

Verder word die belangrikheid van ' $n$ individu se onroerende eiendom ('n huis) in sodanige persoon se boedel in verband gebring met die uiteindelike verkoop daarvan. Juis om hierdie belangrikheid word die toepassing van die Wet op Verbruikersbeskerming ${ }^{4}$ op die koop en verkoop van 'n individu se onroerende eiendom (huis) ook krities ontleed.

Tweede Jaar BCom Regte, Universiteit van Pretoria.

Van der Merwe v Meades 19914 All SA 43 (A).

20072 SA 323 (C).

Van der Merwe (n 1 hierbo).

Wet 68 van 2008, hierna 'die Wet'. 
Derhalwe is die doel van hierdie artikel nie net om bloot informatief die presiese betekenis, inhoud en invloed van die voetstootsklousule te bespreek en te ontleed nie, maar ook die interpretasie van die klousule met spesifieke verwysing na dolus en die invloed daarvan te bevraagteken. Goeie trou word van meet af in ag geneem om nie net die gemeenregtelike perspektief te oorweeg nie, maar ook die toonaangewende statutêre en grondwetlike invloed. Laastens sal die hofsaak van Odendaal $v$ Ferraris ${ }^{5}$ as ' $n$ praktiese geval gebruik word ter illustrasie van die posisie wat in die artikel voorgehou word.

\section{Belang van goeie trou in die Suid-Afrikaanse kontraktereg}

Die belangrikheid van die Romeinse reg lê in die feit dat dit die grondslag van die Suid-Afrikaanse gemenereg vorm. Die beginsel van goeie trou is juis te vinde in die Romeinse reg. Goeie trou staan vandag vas in die Suid-Afrikaanse regstelsel, maar tot welke mate genoemde beginsel 'n daadwerklike invloed op kontrakte het, word toegelig na gelang van drie sake en die Wet op Verbruikersbeskerming.

Eerstens verwys ek na die bekende hofsaak van Sasfin (Pty) Ltd v Beukes. ${ }^{6}$ In hierdie saak is 'n kontrak in sy geheel deur die hof op grond van openbare beleid ongeldig verklaar. Verskeie klousules was so onregverdig en so grof uitbuitend dat die kontrak, na die mening van die hof, nie afgedwing moes word nie. Die openbare belang en goeie trou het dus voorkeur geniet bo pacta sunt servanda. Derhalwe is die beginsel soos volg 'die onredelike en eensydige bevordering van jou eie belang ten koste van ' $n$ ander kan in die uiterste van gevalle die beginsel van goeie trou aantas - in so ' $n$ mate dat dit swaarder weeg as die openbare belang by die streng afdwingbaarheid van kontrakte. ${ }^{\prime 7}$

In die saak van Brisley $v$ Drotsky ${ }^{8}$ het die hof die standpunt ingeneem dat die beginsel in die Sasfin-saak tot gevalle van buitengewone onbillikheid beperk moet word. Alhoewel begrippe soos redelikheid en billikheid die kontraktereg ten grondslag lê, is hierdie waardes slegs abstrakte waardes eerder as substantiewe regsreëls wat deur ' $n$ voorsittende beampte aangewend kan word om by kontraktuele verhoudings in te meng. ${ }^{9}$

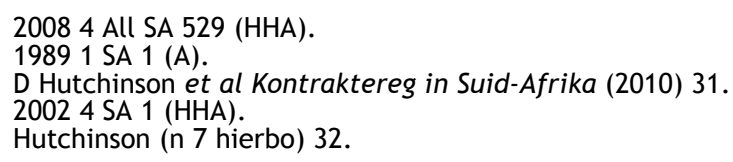


Verder word hierdie begrippe in 'n grondwetlike perspektief gestel in die saak van Barkhuizen: 'Notions of fairness, justice and equity, and reasonableness cannot be separated from public policy. ${ }^{10}$ Die hof het gemeld dat daar by die grondwetlike aanvegting van ' $n$ kontraktuele beding bepaal moet word of die beding wat aangeveg word strydig is met openbare beleid, soos vergestalt in die waardes onderliggend aan ons konstitusionele demokrasie. Laasgenoemde waardes is daardie waardes wat die grondwet as grondslag lê en ook dié wat uiting vind in die Handves van Regte. Derhalwe sal goeie trou steeds ' $n$ integrale rol in kontrakte speel, maar slegs as 'n enkele faktor wat deel vorm van 'n konstitusionele, openbare beleid soos uiteengesit in die Handves van Regte.

Laastens word die Wet op Verbruikersbeskerming in ag geneem en word derhalwe aangevoer dat billikheid en goeie trou statutêr van belang gemaak is en dat dit in teenstryd met grondwetlike oorweging van openbare, belang as 'n faktor per se kan dien om 'n kontrak as $a b$ initio nietig ${ }^{11}$ te ag of te vernietig. Die Wet vermeld die belang daarvan om verbruikers se welstand te bevorder deur die verbuiker te beskerm teen 'gewetenlose, onbillike, onredelike, onregverdige of andersins onbehoorlike handelspraktyke, ${ }^{12}$ en 'oneerlike, misleidende, onbillike of bedrieglike gedrag.

Begrippe soos 'gewetenloos', 'onbillik' en 'onredelik' dui oënskynlik op die beginsel van goeie trou en daar word dus aan die hand gedoen dat waar die Wet op 'n kontrak van toepassing is, goeie trou ' $n$ wesenlike invloed op genoemde kontrak se uitleg en geldigheid het.

\section{Romeinse Reg}

Van meet af aan is ' $n$ verbintenis as ' $n$ regsband (iuris vinculum) beskou. ${ }^{14}$ Hierdie 'band' het sekere gevolge ingehou en soos hieronder aangedui sal word, het sodanige gevolge beduidend verander soos die Romeinse reg ontwikkel het. Hierdie regsband is 'n verbintenis waaraan die reg sekere gevolge heg.

In die Romeinse regstelsel is daar slegs 'n beperkte aantal kontrakte erken en kan geklassifiseer word as óf stricti iuris ${ }^{15}$ óf bonae fidei. ${ }^{16}$ Die belangrikste vereiste vir die totstandkoming van ' $n$

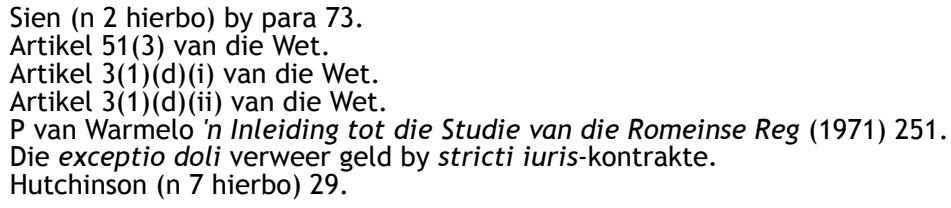


kontrak, hetsy stricti iuris, hetsy bonae fidei, was wilsooreenstemming (consensus). ${ }^{17}$

\subsection{Stricti iuris-kontrakte}

By die bepalings van stricti iuris-kontrakte het goeie trou feitlik geen rol gespeel nie. Howe het geen diskresie gehad nie. Indien die korrekte prosedurele formaat nagekom is, sal die kontrak bindend wees, al was bedrog ten tyde van kontraksluiting aanwesig. ${ }^{18}$ Hierdie kontrakte het 'n obligatio tot gevolg gehad. Laasgenoemde was 'n band wat deur die reg opgelê is waarmee een party (die krediteur) 'n reg het teen die ander party ('n debiteur) se persoon. ${ }^{19}$ Waar die debiteur gevolglik nie sy verpligting nagekom het nie, kon die krediteur letterlik op sy persoon, dit wil sê op homself, beslag lê, en hom verkoop of selfs doodmaak. ${ }^{20}$ Hierby het die handeling ('verkoopshandeling') per se tot gevolg gehad dat 'n verbintenis tot stand kom wat logieserwys neerkom op die handeling mancipatio. 21 Dit sal toepaslik wees om te meld dat hierdie handeling formalisties en streng was. Daar moes aan oudmodiese vereistes, gebruike en tradisies voldoen word ten einde regserkende gevolge aan die bedoeling van die partye te gee. ${ }^{22}$ 'Hier het ons te doen met 'n formele handeling ('n contractus, in die sin van Gaius) waarvolgens die verbintenis tot stand kom. 23

Mancipatio het 'n letterlike gebondenheid veroorsaak en blykbaar begin die begrip obligatio met die gebruik van mancipatio te ontwikkel om later gesien te word as ' $n$ regsband waarvolgens die een party ' $n$ eis teen aan die ander het.

\subsection{Bonae fidei-kontrakte}

Heelwat later het bonae fidei-kontrakte ontwikkel en het die behoefte aan die exceptio doli vervaag tot in 'n fase van ongebruik. ${ }^{24}$ Kontrakte kon nou terug herlei word na die beginsel van goeie trou omrede die konsensuele koopkontrak in die ontwikkelde Romeinse reg 'n kontrak was wat deur die goeie trou beheer is ('n negotium bonae fidei). ${ }^{25}$ In teenstelling met die stricti iuris-kontrakte behels die negotium, waaruit verbintenisse voortvloei (teenoor obligatio) slegs

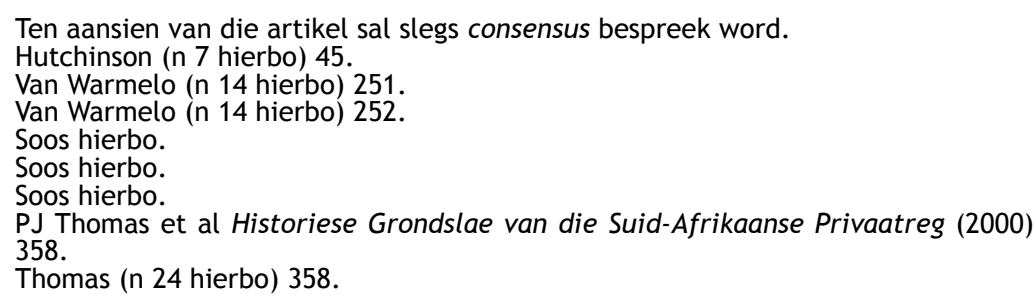


dat, in die geval van 'n konsensuele koopkontrak (emptio et venditio), partye op drie punte moet ooreenkom. ${ }^{26}$ Eerstens moet een party bereid wees om te koop en die ander om te verkoop, tweedens moet die partye eens wees oor die saak wat verkoop word en derdens moet daar eenstemmigheid wees wat betref die prys wat betaal moet word. ${ }^{27}$ Indien die verkoper nie sy verpligtinge nagekom het nie was die aksie genaamd actio empti tot die beskikking van die koper. Met die aksie kon die koper 'n bedrag geld eis wat hom in 'n posisie sou plaas indien die kontrak behoorlik nagekom is. Waar die verkoper bedrieglik opgetree het was die actio empti ook tot die beskikking van die koper waarby die verkoper vir die skade wat die koper gely het aanspreeklik sou wees. ${ }^{28}$ Skadevergoeding kon dus met die actio empti verhaal word.

\subsection{Faktore wat consensus beinvloed}

Sekere gebreke wat consensus beïnvloed is deur die Romeinse reg erken en vervolgens word daarop uitgebrei.

Bedrog (dolus) soos omskryf in Romeinse reg is 'enige geslepenheid, lis of duistere optrede wat daarop gemik was om 'n ander te mislei of te bedrieg'. ${ }^{29}$

Uit bogenoemde word afgelei dat bedrog 'n bedrieglike handeling uitmaak. Sodanige handeling is een wat volgens die algemene opvatting in die gemeenskap as bedrieglik of onfatsoenlik bestempel word, wat juis daarom die saak bemoeilik om die begrip bedrog (dolus) deur middel van 'n klinkklare definisie uit te druk ook, omrede die opvatting van 'n gemeenskap met tyd verander. ${ }^{30}$ Met inagname van voormelde kan bedrog soos volg omskryf word: 'n Opsetlike onregmatige handeling wat gepaard gaan met ' $n$ wanvoorstelling. Die rede hiervoor is oënskynlik dat 'n verkoper 'n wanvoorstelling maak ten aansien van byvoorbeeld die bedinge in die kontrak of waarborge oor die gehalte en toestand van die koopsaak. Hierbo is vermeld dat kontrakte wat op 'n bedrieglike wyse en teen die goeie trou beginsel aangegaan is, onderworpe is aan 'n reeks remedies vir die benadeelde. ' $n$ Kontrak wat gesluit is en waar bedrog ter sprake is, is myns insiens vernietigbaar. Dus kan die benadeelde die kontak beëindig en restitusie eis, vir sover hy vermoënsregtelike skade gely het. Die benadeelde word dan in die finansiële posisie geplaas waarin hy homself bevind het voor kontraksluiting. ${ }^{31}$

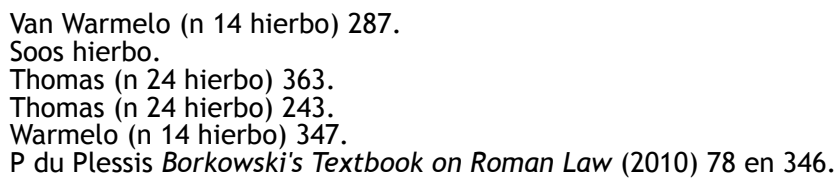


Nalatigheid (culpa) sluit oor die algemeen nie wilsooreenstemming uit nie, maar stel die verkoper aanspreeklik vir vordering en skadevergoeding. Alle skuld word onder culpa verstaan behalwe dolus. Drie vorme ten aansien van culpa word erken, maar slegs een word hier gemeld - culpa lata. 'Growwe nalatigheid [of culpa lata] was vir alle praktiese doeleindes presies dieselfde as dolus.' 32

\subsection{Verpligtinge van die verkoper}

By perfecta-wording van 'n koopkontrak ontstaan daar sekere verpligtinge wat op die verkoper rus waaronder een die waarborg teen verborge gebreke is. ${ }^{33}$

Tesame met vrywaring teen uitwinning het die waarborg teen verborge gebreke met die verloop van tyd ontwikkel. Hierdie verpligtinge tree ipso iure in werking.

\subsubsection{Vrywaring teen uitwinning}

Die vrywaring behels dat die verkoper aan die koper waarborg dat niemand met ' $n$ beter titel die saak of 'n deel daarvan kan uitwin nie. ${ }^{34}$ Vrywaring teen uitwinning is by elke koopkontrak inbegrepe, maar kon deur die partye uitdruklik uitgesluit word. Om laasgenoemde ' $n$ moontlikheid te maak moes beide partye uitdruklik 'n kontrakbeding, naamlik die pactum de non praestanda evictione, insluit. Die pactum de non praestanda evictione kon nie afgedwing word indien die verkoper ' $n$ saak wat hy geweet het aan ' $n$ ander behoort op 'n bedrieglike wyse verkoop het of as hy meegewerk het om uitwinning te bewerkstellig nie. ${ }^{35}$

\subsubsection{Waarborg teen verborge gebreke}

Verborge gebreke is daardie gebreke waarvan die koper nie kennis dra nie en ook nie redelik verwag kan word om van kennis te dra nie. Waar die verkoper kennis van die verborge gebrek dra, kom dit op dolus neer. ${ }^{36}$ 'n Waarborg teen verborge gebreke is een van die verpligtinge, net soos 'n vrywaring teen uitwinning, wat van regsweë by die sluiting van 'n koopkontrak geld. Die oudste remedie was 'n aksie hangende die grootte van grond naamlik die actio de modo agri. Die remedie vind toepassing in 'n geval waar grond deur mancipatio oorgedra is en die verkoper ' $n$ formele verklaring afgelê het oor die grootte van die grond. Die verkoper kon gevolglik aanspreeklik gehou

\footnotetext{
Thomas (n 24 hierbo) 243.

Thomas (n 24 hierbo) 358.

Thomas (n 24 hierbo) 355 .

Thomas (n 24 hierbo) 358 .

Warmelo (n 14 hierbo) 295
} 
word vir dubbeld die waarde van die grond waarmee die grond kleiner is as wat hy verklaar het.

Benewens die actio de modo agri het die aediles curules twee aksies aan die koper toegestaan. Die eerste remedie naamlik actio redhibitoria het ten doel om die partye in die posisie te plaas waarin hulle voor kontraksluiting was. Die koper kon dus die koopprys en die verkoper die koopsaak terugeis. Die actio redhibitoria kan slegs gebruik word indien die terugtrede regverdig is. Die toets daarvoor is of die verborge gebrek so ernstig is dat die koopsaak nutteloos is vir die doel waarvoor dit aangekoop is. ${ }^{37}$ Tweedens is die actio quanti minoris ook tot die verkoper se beskikking wat die koper in staat stel om op ' $\mathrm{n}$ pro rata-vermindering van die koopprys aan te dring. ${ }^{38}$

Hierdie waarborg is deur die Aedilisiese Edik ingevoer en het soos volg bepaal: ${ }^{39}$

Those who sells slaves are to apprise purchasers of any disease or defect in their wares and whether a given slave is a runaway, a loiterer on errands or still subject to noxal liability; all these matters they must proclaim in due manner when the slaves are sold.

Dus is die herkoms van ' $n$ waarborg teen verborge gebreke te vinde by die verkoop van slawe. Ulpianus het dit egter duidelik gestel, soos vervat in die Digesta, dat ' $\mathrm{n}$ verkoper steeds aanspreeklik sal wees al was laasgenoemde onbewus van die latente gebrek. ${ }^{40}$

Dit is egter opvallend dat ' $n$ openbaarmakingsplig op die verkoper rus om enige gebreke waarvan die koper nie van kennis dra nie of verwag kan word om kennis te dra nie, te openbaar. Dus indien die verkoper bewus is daarvan moet hy dit openbaar. Soos reeds aangedui, is die kennisname van die gebrek deur die verkoper nie 'n verweer nie - daarom 'n waarborg teen verborge gebreke.

Let egter op die volgende: ${ }^{41}$

Julian in his fifteenth book (Digest) distinguishes between the knowing and unknowing seller ... He says that if he (seller) acted unknowingly in selling a diseased herd or an unsound timber, then in an action on purchase (actio empti) he will be held responsible for the difference from the smaller amount I would have paid had I known of this. But if he knew but kept silent and so deceived the buyer, he will be held responsible to the buyer for all the losses sustained due to this sale.

Genoemde sluit egter aan by Voet waar hy meld dat 'n verkoper wat geweet het van 'n gebrek aanspreeklik is vir die totale verlies wat

CJ Nagel et al Besigheidsreg (2007) 131.

Nagel (n 36 hierbo).

D.21.1.1.1.

Vergelyk Voet 21, 1, 10 waar Voet dieselfde standpunt inneem en ook verwys na Ulpianus.

D.19.1.13. 
deur die koper gely is as gevolg van die defektiewe produk. ${ }^{42}$ Waar 'n verkoper egter onwetend van die gebrek die saak verkoop het, sal laasgenoemde slegs aanspreeklikheid opgedoen vir sover hy of sy 'n fabrikant is. ${ }^{43}$

Gevolglik is 'n verkoper aanspreeklik, ingevolge die aedilisiese aksies, vir enige verborge gebreke, ongeag of die verkoper kennis gedra het van die gebrek al dan nie. Verder sal die actio empti tot die koper se beskikking wees indien die optrede van die verkoper dolus uitmaak. Die kennis van die verkoper aangaande die gebrek is deurgaans van belang ten einde dolus daar te stel. ${ }^{44}$ Met inagname van bogenoemde word daar aan die hand gedoen dat waar die verkoper kennis van die gebrek dra en waar die koper op grond daarvan bedrieg word, sal hy bykomend tot die aediliesie aksies ook ingevolge die actio empti aanspreeklik wees: ${ }^{45}$

[I]f he knew but kept silent and so deceived the buyer, he will be held responsible to the buyer for all the losses sustained due to this sale. ${ }^{46} \mathrm{~A}$ seller ... who was aware of a defect is liable in addition to make good the whole loss. ${ }^{47}$ If the vendor expressly exclude some disease and, for the rest, declare the slave healthy or give security in respect thereof, the agreement made is to be observed (for there is no return for those who forego their redress) unless the vendor, knowing of the disease, deliberately kept silent about it; in such case, the defence of fraud will be available.

Waar die koper vergoeding vir gevolgskade wil eis, moet die hy van die actio empti gebruik maak, maar dan moet hy bewys dat die verkoper ten tyde van kontraksluiting bewus was van die verborge gebreke dog dit bedrieglik (dolo malo) verswyg het. ${ }^{48}$

Soos duidelik blyk, is die koper deurlopend teen verborge gebreke beskerm. Die uitsluiting van 'n waarborg teen verborge gebreke geld in beginsel, met verwysing na die substantiewe inhoud, op presies dieselfde manier as die van vrywaring teen uitwinning. In die geval waar die waarborg teen verborge gebreke uitgesluit word, word die werking van die aedilisiese aksies dienooreenkomstig onmoontlik. Nes die pactum de non praestanda evictione is die uitsluiting van die waarborg teen verborge gebreke 'n uitsluitingsklousule en sodanig sal die vereistes van eerlikheid (bona fides) sowel as die onkunde van die verkoper aangaande die verborge gebrek ook geld.

D.21.1.10.

CJ Nagel et al Kommersiële Reg (2011) 223.

D.21.1.1.2; D.18.1.43.2; D.19.1.13; Voet 21.1.10.

D.21.14.9.

D. $19,1.13$.

Voet 21.1.10

P van Warmelo Vrywaring teen Gebreke by Koop in Suid-Afrika Proefskrif (1941) 53. 
Die basis van die Romeinse kontraktereg is toegelig met verwysing na hoe 'n kontrak tot stand kom, watter gebreke die kontrak beïnvloed sowel as toepaslike verpligtinge van die verkoper waarop die koper geregtig is. Vervolgens word die voetstootsklousule bespreek.

\section{Voetstootsklousule: 'n Oorsig}

'Daar is ' $\mathrm{n}$ verskeidenheid van klousules wat die aanspreeklikheid van die verkoper inperk wat onder die vaandel van die klousule vaar., 49 Vir die doeleindes van die artikel word die bespreking beperk tot 'n geval waar 'n saak voetstoots verkoop word. So 'n klousule is bloot daarop gemik om die verkoper van sy vrywaringsplig te onthef en sodanig word die Aediliese Edik se werking uitgesluit. ${ }^{50}$ Myns insiens sluit die klousule enige waarborg teen verborge gebreke en gevolglik ook die vrywaringsplig van die verkoper, uit. ${ }^{51}$ Aanspreeklikheid vir onskuldige wanvoorstellings moet ook aangespreek word. In die saak van Cockroft $v$ Baxter ${ }^{52}$ beslis Regter Ogilvie Thompson dat 'n voetstootsklousule wel aanspreeklikheid vir onskuldige wanvoorstelling kan uitsluit mits dit so bewoord is, maar dat 'n blote voetstootsklousule dit nie doen nie. Hy onderskei tussen wanvoorstellings wat op die kwaliteit van die saak en wanvoorstellings wat op omstandighede wat die waarde van die saak affekteer, gemik is.

By eersgenoemde is daar op 'n ooreengekome kwaliteit van die koopsaak gekontrakteer. ${ }^{53}$ Dus, indien ooreengekome kwaliteit op 'n dictum et promissum neerkom, kan die insluiting van die voetstootsklousule nie die aanspreeklikheid vir die afwesigheid van die gewaande kwaliteit uitsluit nie. In beginsel kan 'n klousule nie uitgesluit word deur 'n klousule in te sluit wat eersgenoemde uitsluit en gevolglik nutteloos laat nie. Tweedens, '[i]n die RomeinsHollandse reg, waar die voetstootsklousule sy oorsprong vind, was onskuldige wanvoorstelling as grond van aksie onbekend, sodat aanspreeklikheid daarvoor nie deur die voetstootsklousule uitgesluit is nie'. ${ }^{54}$ Let daarop dat die klousule kan bepaal dat die verkoper geen aanspreeklikheid sal dra vir enige voorstellings ten opsigte van verborge gebreke nie en dus voldoen dit aan die 'bewoording' soos bedoel deur Regter Ogilive Thompson. ${ }^{55}$

GL Grobler Die Grondslag vir die Aanspreeklikheid van die Verkoper Weens Gebreke in die Koopsaak (1974) 219.

19554 SA 93 (K) 96.

Sien hierbo 'Waarborg teen verborge gebreke'.

1955 All SA $184(\mathrm{~K})$.

Vergelyk met die dictum et promissum soos in Phame (Pty) Ltd v Paizes 19733 All

SA 501 (A)

Grobler (n 48 hierbo) 222.

Cockroft $\vee$ Baxter (n 54 hierbo). 
'n Verborge gebrek behels, soos beslis in Holmdene Brickworks (Pty) Ltd v Roberts Construction Co Ltd ${ }^{56}$ 'n abnormale kwaliteit of eienskap wat die gebruiksnut van die koopsaak vernietig of wesenlik belemmer vir die doel waarvoor die merx gekoop is of waarvoor dit normaalweg gebruik word. Die hof het egter nagelaat om te beslis watter van die volgende aanwending moet vind. Moet die gebrek maklik waarneembaar of redelik waarneembaar wees, of moet dit redelikerwys waarneembaar wees deur 'n gewone koper? In die saak van Van der Merwe $v$ Meades ${ }^{57}$ is die posisie soos volg uiteengesit: In die Romeinse reg, by die sluiting van die kontrak, moes die koper onbewus gewees het van die bestaan van die gebrek. Die feit dat die verkoper by kontraksluiting van die gebrek onbewus was, was irrelevant. Kragtens die aedilisiese aksies, in die geval van verborge gebreke, was daar geen eis tot die beskikking van die koper en vir skadevergoeding nie en kon hy slegs skadevergoeding eis met die actio empti, mits hy kon bewys dat die verkoper ten tyde van kontraksluiting van die gebrek bewus was en dat hy die verborge gebrek dolo malo (opsetlik met die bedoeling om te bedrieg) verswyg het. ${ }^{58}$

Derhalwe kan die hedendaagse verborge gebrek, soos volg omskryf word: ${ }^{59}$

'n Gebrek in 'n koopsaak van 'n nie-onbenullige aard wat die gebruiksnut van die koopsaak affekteer en wat nie tydens die kontraksluiting aan die koper bekend was nie en ook nie met redelike sorgbesteding deur hom opgemerk kon word nie. [eie beklemtoning]

Vervolgens kan die voetstootsklousule soos volg omskryf word: 'n Voetstootsklousule is 'n uitsluitingsklousule wat spesifiek daarop ingestel is om die verkoper se ipso iure waarborg teen verborge gebreke uit te sluit. Hieruit spruit twee toepaslike vrae: Eerstens, is die blote kennis van 'n verborge gebrek genoeg om die verkoper aanspreeklik te stel? Tweedens moet vasgestel word of die verswyging van die gebrek met ' $n$ opset om te bedrieg gepaard moet gaan. Ten einde gestelde vrae te beantwoord word daar na hofsake verwys.

In Hadley $v$ Savory ${ }^{60}$ is ' $n$ perd voetstoots verkoop waar die verkoper van 'n latente gebrek bewus was. Regterpresident De Villiers baseer sy uitspraak op Voet. ${ }^{61}$ Sy interpretasie daarvan is dat wanneer die verkoper bewus is van 'n latente gebrek en met die aangaan van 'n kontrak 'n voetstootsklousule insluit, dit op bedrog neerkom.

19774 All SA 94 (A) soos bespreek in DJ Lötz Besondere Kontrakte in die Hof (2007) 57

19914 All SA 43 (A) soos bespreek in DJ Lötz Besondere Kontrakte in die Hof (2007) 5.

58 Soos bespreek in Lötz (n 57 hierbo) 62.

59 Nagel (n 43 hierbo) 223. Sien ook Dibley v Further 195194 SA 73 (K); Holmdene (n 56 hierbo)

601916 TPA 385 bl46 A.

61 D.21.1.10.10. 
Vervolgens verwerp hy die verweerder se argument dat die eiser nie aangetoon het dat hy bedrieglik gehandel het nie. ${ }^{62}$

In Van der Merwe $v$ Culhane $e^{63}$ verkoop die eiser 'n huis voetstoots aan die verweerder. Ten tyde van kontraksluiting is die eiser bewus dat daar boorkewer in die houtwerk van die huis is, maar openbaar dit nie aan B nie. Waarnemende Regter Bresler verwys ook na Voet: ${ }^{64}$

Dit is waar dat Voet sê dat die verkoper slegs gebonde is as hy die gebrek opsetlik versteek. Uit die tekste waarop Voet steun is dit egter duidelik dat juis deur ' $\mathrm{n}$ voetstootsklousule in die kontrak in te sluit terwyl hy van die gebrek weet, hy die gebrek opsetlik versteek.

In die saak van Van der Merwe $v$ Meades het die hof die gemenereg uitgelê en tot die gevolgtrekking gekom dat die Romeinse posisie net so in die Romeins-Hollandse reg oorgeneem is. Beide laaste twee genoemde sake is deur die hof verwerp en daar is beslis deur die hof dat waar 'n koper die voetstootsklousule wil aanveg moet die koper nie net bewys dat die verkoper daadwerklik van die verborge gebrek bewus was nie, maar dat laasgenoemde dit dolo malo verswyg het.

Met respek, die hof het hier gefouteer deur om die onus wat verlang word ten einde die aedilisiese aksies te verwar met dié van skadevergoeding. Alhoewel die voetstootsklousule die aedilisiese aksies se werking uitsluit kan 'n kontraktuele klousule nie die onus van die koper verhef nie.

Dit is duidelik, in die afwesigheid van die voetstootsklousule, dat waar die verkoper weet van die verborge gebrek sal die verkoper steeds aanspreeklik wees ingevolge die aedilisiese aksies. Waar die koper skadevergoeding wil eis, moet hy bewys dat die verkoper die verborge gebrek verswyg het met die bedoeling om te bedrieg (dolo malo). ${ }^{65}$ Tot op hierdie stadium word daar aan die hand gedoen dat die benadering korrek is, maar neem die volgende situasie as ' $n$ voorbeeld. 'n Verkoper verkoop sy huis voetstoots. Die huis het 'n verborge gebrek, waarvan die verkoper kennis gedra het ten tyde van kontraksluiting. Die koper kan nie die kontrak kanselleer en restitusie eis nie (actio redhibitoria). Hy kan ook nie 'n pro rata-vermindering van die koopprys eis nie (actio quanti minoris), tensy hy dolo malo verswyging deur die verkoper bewys. Let daarop dat sonder die klousule, sou die verkoper, al het hy kennis van die gebrek gedra al dan nie, aanspreeklik wees ingevolge die aedilisiese aksies. Hoekom nou waar die verkoper die voetstootsklousule insluit word die koper belas met dieselfde bewyslas om skadevergoeding, in die afwesigheid van die voetstootsklousule, te kan eis? 
Dit is die mening van die skrywer dat waar daar sprake van 'n voetstootsklousule is, die definisie van 'n verborge gebrek dienoor eenkomstig aangepas moet word na 'n tweeledige definisie. Hierdie definisie sal soos volg lui: 'n Gebrek van 'n nie-onbenullige aard wat die gebruiksnut van die merx affekteer en waarvan beide die koper sowel as die verkoper ten tyde van kontraksluiting onbewus is. Omrede die verkoper toekomstige aanspreeklikheid, wat hy ten doel het om juis nie voor aanspreeklik te wees nie, met die voetstootsklousule kan uitsluit, ${ }^{66}$ moet die definisie derhalwe aangepas word omrede dit onbillik, onregverdig en onredelik teenoor die koper sal wees indien die verkoper sodanige aanspreeklikheid kan uitsluit met deeglike kennis van die verborge gebrek en in die posisie geplaas word waar die koper 'n verhewe onus dra.

Verder kan ook geredeneer word dat waar 'n persoon, wie bewus is van ' $n$ verborge gebrek en steeds die voetstootsklousule insluit en die gebrek verswyg, se optrede outomaties neerkom op 'n opsetlike verswyging met die bedoeling om die koper te bedrieg.

Ten slotte het die hof in Truman $v$ Leonard ${ }^{67}$ beslis dat waar 'n kontraktuele beding weens bedrog tot stand kom, sodanige beding op grond van openbare belang regtens onafdwingbaar is. Derhalwe waar 'n verkoper ' $n$ verborge gebrek bedrieglik verswyg, moet 'n voetstootsbeding nie weggedink word nie. Die beding sal steeds staan, maar 'n verkoper sal slegs daarop kan steun vir sover hy of sy eerlik gehandel het. Die hof het Voet aangehaal ter ondersteuning van sy beslissing: ${ }^{68}$

For the rest a seller who was aware of a defect will not be excused by the fact that at the time of sale he generally agreed and declared that he was selling the thing such as it is, and that he did not wish to be held liable for its defects and diseases. That is because by such a general form of words he appears to have spoken darkly in artfulness and trickery; and it is a clear inference from the passages cited below that such a person is in every way held liable.

Dit is dus duidelik dat indien die voetstootsklousule ingesluit is terwyl die verkoper van die verborge gebrek weet hy ten doel het om dit met opset te versteek ${ }^{69}$ en tree hy bedrieglike op. Dit kom neer op dolus en is teenstrydig met die bonae fidei beginsel. Derhalwe moet in die geval waar 'n die voetstootsklousuleingesluit word, 'n definisieverandering van ' $n$ verborge gebrek plaasvind. Dit is duidelik dat waar iemand tot sy eie voordeel en ten koste van ' $n$ ander party kontraktuele aanspreeklikheid kan uitsluit dit nie in die openbare

Ingevolge die huidige definisie soos aanvaar deur die positiewe reg. 19944 All SA 445 (SOK).

D.21.1.10.

In die sin om inligting van die koper te weerhou, nie fisiese veranderinge aanbring nie. 
belang kan wees nie. ${ }^{70}$ Dus sal die 'n eis om skadevergoeding outomaties volg in omstandighede waar die verkoper die voetstootsklousule insluit en die verborge gebrek verswyg. Met inagneming van die bogenoemde, is die onus wat deur die koper gedra word onnodig, en met respek verkeerdelik, ten gunste van die verkoper uitgelê. ${ }^{71}$ Die onus van die hof is dus regverdigbaar in die afwesigheid van die voetstootsklousule en nie in die aanwesigheid daarvan nie.

\section{$5 \quad$ Die Wet op Verbruikersbeskerming}

Die Wet het 'n diepgaande impak op kontrakte waar dit regte aan die verbruiker verleen en verpligtinge vir die verskaffer daarstel. Vervolgens word die impak van genoemde wet bespreek met inagname van die wisselwerking tussen dolus en die voetstootsklousule. Daar is wel in ag geneem dat die Wet sy herkoms vind vanuit die Kanadese reg, maar om regsvergelyking effektief toe te pas en van belang te maak in die artikel is egter nie moontlik nie vanweë die uiteenlopende aard van die wetgewing wat verbruikerbeskerming in Suid-Afrika en Kanada reël. ${ }^{72}$

\subsection{Is die Wet van toepassing?}

Eerstens moet vasgestel word of die Wet van toepassing is op ' $n$ natuurlike persoon of ' $n$ individu, wat sy of haar onroerende eiendom of verblyfplek, aan 'n ander individu verkoop. ${ }^{73}$ Ingevolge die Wet is 'n verskaffer iemand wat goedere en dienste bemark. ${ }^{74}$ Artikel 5(8)(c) bepaal dat die Wet van toepassing is ongeag of die verskaffer ' $n$ individu is. Met ander woorde ' $n$ individu is ' $n$ verskaffer vir die doeleindes van die Wet. Verder is 'n verbruiker iemand aan wie die bepaalde goedere of dienste in die gewone loop van die verskaffer se besigheid bemark word. Die vraag ontstaan egter: Wat is in die gewone loop van die individu se besigheid? Is dit in die gewone loop van ' $n$ individu se besigheid om eenmalig of menigmale sy of haar onroerende eiendom te verkoop? Wat egter duidelik is, is dat 'n individu in die gewone loop van sy of haar lewe 'n ooreenkoms

Vergelyk Sasfin (n 6 hierbo) en Truman (n 71 hierbo).

Van der Merwe (n 58 hierbo).

Roger Tassé, OC 'Consumer protection rights in Canada in the context of electronic commerce' (1998) in 'n verslag aan die Kanadese Kantoor vir die Verbruikersaffêre Industrie http://cmcweb.ca/eic/site/cmc-cmc.nsf/vwapj/ cdrcec_e.pdf/\$FILE/cdrcec_e.pdf (besoek op 3 Maart 2013).

73 Vergelyk W Jacobs et al 'Fundamental consumer rights under the Consumer Protection Act 68 of 2008: A critical overview and analysis' (2010) 13 Potchefstroomse Elektroniese Regsjoernaal 3, waar tot die gevolgtrekking gekom 74 is dat ' $n$ hof duidelikheid hieroor moet bied.

74 Artikel 1 van die Wet. 
(kontrak) kan aangaan om sy of haar onroerende eiendom te verkoop. ${ }^{75}$

Soos hieronder vermeld, is daar in 'n ooreenkoms wat op die verskaffing van goedere ${ }^{76}$ betrekking het 'n versweë waarborg dat die goedere en dienste aan vereiste standaarde voldoen. Dit is belangrik om op die gebruik van die woord 'ooreenkoms' te let wat die Wet definieer as ' $n$ reëling of verstandhouding tussen twee of meer partye wat voorgee om 'n regsverhouding tussen hulle te vestig. ${ }^{77}$ Dit het tot gevolg dat ' $n$ individu' $n$ ooreenkoms ingevolge die Wet kan aangaan ten einde sy of haar onroerende eiendom te verkoop en ook die beskerming van artikel 56 van Die Wet geniet, omrede die omskrywing van 'ooreenkoms' geensins van 'in die gewone loop van die verskaffer se besigheid' melding maak nie. Genoemde versweë waarborg word gemaak deur, onder andere, 'n kleinhandelaar wat die produk moet verskaf. ${ }^{78}$ ' $n$ Individu is ' $n$ verskaffer, soos reeds genoem, en dus kan 'n individu, analoog, as 'n kleinhandelaar, soos gedefinieer deur die Wet, gesien word.

Die Wet verleen en versterk spesifieke regte aan verbruikers soos byvoorbeeld 'die reg op gelyke behandeling in die markplek'. ${ }^{79}$ Dit is seker dat waar onroerende eiendom deur 'n eiendomsontwikkelaar aan 'n verbruiker verkoop word die verbruiker die beskerming van die Wet sal geniet. ${ }^{80}$ Waarom dan kan 'n verbruiker wat nie onroerende eiendom vanaf 'n ontwikkelaar aankoop nie, nie die beskerming van die Wet geniet nie? Juis as gevolg van die aard van onroerende eiendom met betrekking tot ' $n$ individu se boedel, met ander woorde die belangrikheid van onroerende eiendom as ' $n$ bate vir ' $n$ individu, sal dit voordelig wees, bykomend tot gemeenregtelike reëls, om 'n individu se vermoënsregtelike belang in sodanige onroerende eiendom te beskerm, ongeag of die eiendom aangekoop is van ' $n$ eiendomsontwikkelaar, al dan nie.

Verder word daarop gewys dat die Wet op Vervreemding van Grond $^{81}$ spesifieke formaliteitsvereistes vir die vervreemding van onroerende goed voorskryf. Hierdie is egter die uitsondering op die algemene reël ingevolge die gemenereg, dat geen formaliteitsvereistes vir die totstandkoming van 'n geldige kontrak vereis word nie, tensy partye tot die teendeel ooreenkom. ${ }^{82}$ 'n Standpunt wat ingeneem kan word is dat vanweë die belangrikheid van onroerende eiendom, statutêre vereistes in plek gestel is ten einde dit voldoende

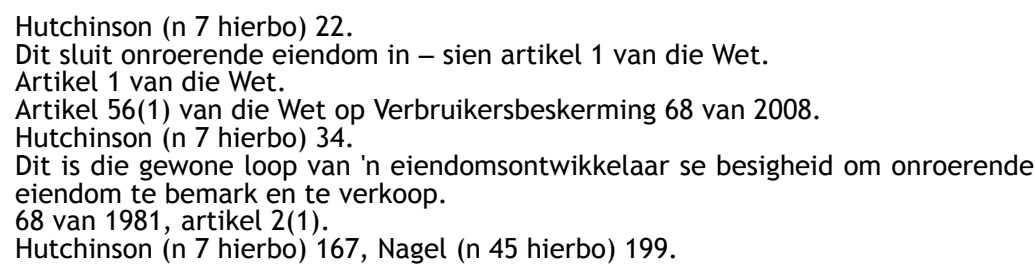


te reguleer. In die saak van Clements $v$ Simpson ${ }^{83}$ bevestig die hof dat die wetgewer formaliteite vereis om onsekerhede te voorkom, dispute uit te sluit en wanpraktyke teë te werk.

Dus is dit die mening van die skrywer dat die Wet toepassing vind in 'n geval waar een individu sy of haar onroerende eiendom of verblyfplek, aan 'n ander individu verkoop.

\subsection{Invloed van die Wet}

Volgens die Wet het elke verbruiker die 'reg om goedere te ontvang wat van goeie gehalte, in 'n goeie werkende toestand en vry van enige defekte is' ${ }^{84}$ 'Dit is nie ter sake of die produkgebrek of defek verborge of sigbaar is nie, en of dit voor ontvangs van goedere deur ' $n$ verbruiker opgemerk kon word nie. ${ }^{85}$ In 'n ooreenkoms wat op die verskaffing van goedere aan 'n verbruiker betrekking het, is daar 'n versweë bepaling dat die kleinhandelaar waarborg dat die goedere aan die vereistes en standaarde voldoen soos beoog in die Wet. ${ }^{86}$

Voor die inwerkingtreding van die Wet is 'n onderskeid tussen 'n latente en -patente gebrek gemaak. ${ }^{87}$ Die kennisname van die gebrek is ook verslap in die sin dat daar nie van 'n verbruiker verwag word om die gebrek 'op te merk' nie. Verder is die werking van die voetstootsklousule drasties ingeperk aangesien die bepalings (supra) nie van toepassing is nie: ${ }^{8}$

[I]ndien die verbruiker uitdruklik ingelig is dat bepaalde goedere in 'n spesifieke toestand aangebied is nie; en uitdruklik toegestem het om die goedere in daardie toestand te aanvaar, of wetend op ' $n$ wyse opgetree het wat bestaanbaar is met aanvaarding van die goedere in daardie toestand nie.

Binne ses maande na die lewering van goedere kan 'n verbruiker dit aan die verskaffer teruggee sonder boete en op die verskaffer se onkoste en risiko, indien die goedere nie aan die vereistes en standaarde (supra), voldoen nie. Die verskaffer moet die gebrekkige, onveilige of defektiewe goedere herstel of vervang; of die prys deur die verbruiker vir die goedere betaal, aan die verbruiker terugbetaal. ${ }^{89}$ Die verbruiker kan nóg die onroerende eiendom aan die verskaffer teruggee en die verskaffer kan nóg die onroerende eiendom vervang. Die verskaffer kan steeds die onroerende eiendom op sy onkostes herstel.

19713 All SA 196 (A).

Artikel 55(2)(b) van die Wet.

Artikel 55(5)(a) van die Wet.

Artikel 56(1) van die Wet.

Artikel 55(5)(a) van die Wet.

Artikel 55(6)(a)-(b) van die Wet.

Artikel 56(2)(a)-(b) van die Wet. 
Die remedies ingevolge artikel 56(2) moet binne ses maande afgedwing word, maar die versweë waarborg bly voortbestaan vir 'n onbepaalde tydperk. Die voetstootsklousule het geen invloed op hierdie waarborg nie aangesien hierdie waarborg slegs oorkom (uitgesluit) word deur om aan die vereistes van artikel 55(6) te voldoen. Hierdie versweë waarborg is bykomend tot die gemeenregtelike waarborg. ${ }^{90}$ In die skrywer se opinie het die Wet tot gevolg dat twee waarborge nou bestaan. Eerstens die waarborg soos vervat in artikel 56 en tweedens die gemeenregtelike waarborg teen verborge gebreke. ${ }^{91}$ In die eerste ses maande geld die versweë waarborg om aan die bepalings van die Wet te voldoen wat die verbruiker teen beide latente en patente gebreke beskerm. Die gemeenregtelike waarborg geld steeds, maar die statutêre waarborg is meer voordelig vir die verbruiker. Wat egter nadelig is van die statutêre waarborg is dat dit sal verval omdat sy remedies onderworpe is aan ' $n$ tydsbeperking. ' $n$ Bepaling sonder remedies om dit af te dwing is myns insiens ' $n$ onafdwingbare bepaling. Vervolgens kan 'n voetstootsklousule ingesluit word, maar om die versweë waarborg uit te sluit moet daar aan artikel 55(6) voldoen word. 'n Voetstootsklousule, soos bedoel in die artikel, kan nie die versweë waarborg uitsluit nie omrede ' $n$ beding nie strydig met wetgewing mag wees nie. ${ }^{92}$

In die saak Trollip $v$ Jordaan ${ }^{93}$ het die appellant 'n plaas van die respondent gekoop ingevolge 'n koopkontrak wat die grense en grootte van die plaas korrek weerspieël het. Die appellant is egter mislei om te glo dat die plaas meer beboste grondgebied ingesluit het as wat die geval was, omdat die respondent se agent die grense van die plaas verkeerdelik aangedui het. ${ }^{94}$

The statement in clause 1 that the property is sold voetstoots, that is to say, as seen, inspected and approved by the purchaser does not, as I have previously mentioned, refer to the area of land alleged to have been pointed out by the respondent to the appellant sixteen months before the signing of the deed of sale; it clearly and specifically refers to the property as defined in the deed of sale. The deed does not state that the appellant is buying the land which was pointed out to him; it declares unambiguously that the appellant is buying the property described in the deed of sale and that he has seen, inspected and approved of that property. What is more, that is the very property which the respondent, in terms of the deed of sale, is selling to the appellant.

Deur die klousule in te sluit het die appellant die eiendom gekoop soos beskryf in die koopkontrak. Dus is die appèl van die hand gewys.

Artikel 56(4) van die Wet.

Sien hierbo 'Waarborg teen verborge gebreke'.

Nagel ( $\mathrm{n} 45$ hierbo) 44

19611 SA 238 (A)

Soos hierbo 93. 
Vervolgens word afgelei dat 'n voetstootsklousule egter bykomend kan bepaal dat die verskaffer aan die vereistes van artikel 55(6) voldoen het, in sover dit werklik aan voldoen is, of indien dit by noodwendige implikasie sal blyk uit die gedrag van die verbruiker dat daar aan die genoemde artikel voldoen sal word. Die gemeenregtelike vermoede dat wetgewing nie bestaande reg onnodig wysig nie dien ook as 'n grond vir die gevolgtrekking dat die werking van die voetstootsklousule steeds geld soos voor die Wet, net ondergeskik aan die Wet.

\section{Odendaal $v$ Ferraris $^{95}$}

Met inagname van die algehele posisie soos geskets in die artikel word die beslissing van die saak in oënskou geneem en word dit krities ondersoek teen die gemeenregtelike agtergrond en die positiefregtelike toepassing daarvan. Daarna word die Wet op Verbruikersbeskerming op die feitlike agtergrond van die saak toegepas.

In hierdie saak het die respondent, Kevin Ferraris, ' $n$ woonhuis by die applikant, Talita Odendaal, gekoop onderworpe aan 'n voetstootsklousule. Nadat die respondent die eiendom bewoon het, het hy ' $n$ reeks defekte ontdek wat nie aan hom bekend gemaak is nie. Daarna het hy die applikant in kennis gestel dat hy instruksies vir sy bank gegee het om die betaling van die eiendom uit te stel. Die applikant het gevolglik aansoek gedoen om die respondent te verplig om die eiendom te ontruim.

Die respondent het verskeie defekte aan die hof gestel, byvoorbeeld dat die plafon tekens van ernstige waterbeskadiging toon en gedeeltelik ineengestort het, dat die riool mangat versteek was gedurende hul inspeksie van die woonhuis en dat die trappe bedek is met dierevelle met die doel om die defek te versteek. Die trappe het die eerste aand nadat hulle ingetrek het in duie gestort. Met die insluiting van die voetstootsklousule meen die applikant dat sy vrygespreek is van enige aanspreeklikheid ten aansien van genoemde gebreke.

Die hof volg dus die posisie soos uiteengesit in Van der Merwe $v$ Meades. Die riool mangat en die trappe is beide bedek en juis daarom is beide gebreke vervorm in verborge gebreke. Met respek, kan 'n verborge gebrek nie versteek word nie, juis omdat dit verborge is. Wanneer ' $n$ gebrek versteek word is dit nie ' $n$ verborge gebrek nie, maar 'n versteekte gebrek. Dus het die hof verwag dat die koper nie net kennisname van 'n gebrek moet bewys waarvan die verkoperindien hy kennis daarvan dra, nie moet bedrieglik verswyg nie. 
Verder, waar die verkoper hierdie 'verborge' gebrek versteek word daar bykomend van die koper verwag om bedrieglike versteking te bewys. Soos reeds vermeld, deur ' $n$ huis voetstoots te verkoop en van 'n verborge gebrek kennis te dra kom neer op dolus wat dus beteken dat 'n persoon nie hoef te bewys dat 'n gebrek op 'n spesifieke manier versteek moet word om op bedrog neer te kom nie.

In die verdediging kon die respondent nie bewys dat die applikant van enige gebrek geweet het nie en ook nie dat sy dit van hom weerhou het nie. Die trappe was bedek, maar die respondent het nooit aangevoer dat die applikant dit so bedek het met die doel om 'n gebrek te versteek nie en dieselfde geld vir die riool mangat. Daar is deur die applikant erken dat die mangat bedek is, maar dat dit met redelike sorg deur die respondent opgemerk kon word en dus nie 'n verborge gebrek is wat weerhou is nie. Laasgenoemde is 'n praktiese voorbeeld van die oorlaaide onus van 'n koper. Daar is in casu die standpunt ingeneem dat daar redelikerwys van enige koper verwag kan word dat 'n verkoper ' $n$ rioolmangat, in 'n waskamer, met ' $n$ kartonboks kan bedek. Die vraag is egter watter nugterdenkende, redelike, koper sou verwag dat waar 'n kartonboks in 'n waskamer geplaas is dat hierdie boks 'n rioolmangat sal bedek?

Die respondent kon ook nie bewys dat die applikant van die gebreke geweet het ten tye van kontraksluiting nie. ${ }^{96}$ Die hof het beslis dat die respondent die eiendom moet verlaat aangesien die voetstootsklousule die applikant beskerm en die respondent nie dolo malo verswyging kon bewys nie.

'n Aangepaste beslissing, wat met bepalings en doel van die Wet op Verbruikersbeskerming strook word vervolgens uiteengesit. Die respondent het 'n reg om goedere te ontvang wat van 'n goeie gehalte, in ' $n$ goeie werkende toestand en vry van enige defekte is. ${ }^{97}$ Tesame met die versweë waarborg is die applikant aanspreeklik vir enige defekte, latent of patent. Dus in die eerste ses maande sal die respondent verplig word om die plafon te vervang, verantwoording te doen vir die rioolmangat en die herstelkoste van die trappe. Die insluiting van die voetstootsklousule sal nie die respondent vryspreek van die verpligting ingevolge artikel 55 nie. ${ }^{98}$

Die respondent het die gebreke onder die applikant se aandag gebring voordat die ses maande tydperk verstryk het. 'n Aangepaste uitspraak word nou voorgehou:

(1) Die respondent kan nie verplig word om die eiendom te verlaat, indien hy dit nie sou verkies nie. Vervolgens word die appèl van die hand gewys. 
(2) Aanspreeklikheid vir enige gebreke, latent of patent, in die woonhuis, wat nie ontstaan het as gevolg van die gebruik daarvan deur die respondent nie, is die van die applikant.

\section{Slotopmerkings}

Die interpretasie ten aansien van die onus wat deur die koper gedra word, moet aangepas word soos reeds gemeld. Verder sluit verborge gebreke nie versteekte gebreke in nie en versteking van 'n gebrek gee per se aanleiding tot dolus. Die posisie wat ingeneem word dat daar 'n definisieverandering plaasvind by die insluiting van die voetstootsklousule is myns insiens in lyn met ' $n$ openbare beleid soos te vinde in die Handves van Regte en ook in die Wet op Verbruikersbeskerming.

Met verwysing na die hofsaak van Trollip $v$ Jordaan $^{99}$ word analogies afgelei dat ' $n$ voetstootsklousule slegs kan stipuleer dat daar aan artikel 55(6) se vereistes voldoen is, of aan voldoen kan word, maar kan nie die werking van die artikel uitsluit, soos wat die klousule steeds ' $n$ verkoper se waarborg teen verborge gebreke kan uitsluit nie. Die bepalings van die Wet is onduidelik en abstrak. Soos vermeld is daar nou twee waarborge, die eerste wat statutêr van aard is en die tweede wat gemeenregtelik van aard is. 'n Ander interpretasie wat verneem dat ' $n$ voetstootsklousule regtens nie meer kan bestaan nie kan myns insiens nie korrek wees nie. Indien sodanige interpretasie ondersteun word, beteken dit dat die Wet die gemeenregtelike waarborg teen verborge gebreke vervang het, wat teenstrydig met artikel 55(6) van die Wet is. 



\title{
TUG OF WAR: EVALUATIVE VERSUS FACILITATIVE MEDIATOR
}

\author{
By Diksha Munjal*
}

\section{Introduction}

Mediation can be defined as a process where a neutral third party seeks to facilitate communication between the disputing parties to help them arrive at an amicable solution of their disputes culminating in a win-win situation for the parties. Though '.. there is no single limiting definition of mediation, in part because mediators function in accordance with different philosophies and in statistically different ways', 1 the most commonly accepted definitions of mediation ${ }^{2}$ incorporate two essential elements: '(1) third-party facilitation of dispute settlement, and (2) lack of third-party power to determine

Research Associate, National Law University Delhi.

MS Levin 'The propriety of evaluative mediation: concerns about the nature and quality of an evaluative opinion' (2001) 16 Ohio State Journal on Dispute Resolution 267.

$2 \mathrm{Eg}$ on certain aspects of mediation in civil and commercial matters. Council Directive (EC) 2008/52 (2008) OJ L136/3 art 3(a) http://www.eur-lex.europa.eu/ LexUriServ/LexUriServ.do?uri=OJ:L:2008:136:0003:0008:EN:PDF (accessed on 11 November 2011) (hereinafter 'EC Directive'). It defines mediation to mean: a structured process, however named or referred to, whereby two or more parties to a dispute attempt by themselves, on a voluntary basis, to reach an agreement on the settlement of their dispute with the assistance of a mediator. This process may be initiated by the parties or suggested or ordered by a court or prescribed by the law of a Member State. The Law Society 'Civil and commercial mediation accreditation scheme: criteria and guidance notes, annex- $B$ ' in The Law Society code of practice for civil and commercial mediation (July 2009) sec 1 http:// www.lawsociety.org.uk/new/documents/accreditation/ccmas_guidance.pdf (accessed on 11 November 2011) (hereinafter 'Annex-B CPCCM'). It defines mediation as: a process in which two or more parties in dispute whether or not they are legally represented and at any time, whether or not there are or have been legal proceedings agree to the appointment of a neutral third party (the mediator) who is impartial, who has no authority to make any decisions with regard to their issues, which may relate to all or any part of a dispute of a civil or commercial nature, but who helps them reach their own decisions by negotiation without adjudication. The Law Society 'Family Mediation Accreditation Scheme: Criteria and guidance notes, Annex-A 'in the The Law Society code of practice for family mediation (July 2009) sec 1 http://www.lawsociety.org.uk/new/ documents/accreditation/family-mediation-accreditation-scheme-guidance.pdf (accessed on 13 November 2011) (hereinafter 'Annex-A CPFM'). Defines 'family mediation' on similar lines. College of Mediators Code of practice for mediators (2008) para 1.2 http://www.collegeofmediators.com/index.php?option=com_rok downloads\&view=file\&ltemid=18\&id=5: code-of-practice (accessed on 13 November 2011) (hereinafter 'CMCPM'). It defines mediation as: a process in which an impartial third party assists those involved in a conflict to communicate better with one another and reach their own agreed and informed decisions concerning some, or all, of the issues in the dispute. RAB Bush 'The dilemmas of mediation practice: A study of ethical dilemmas and policy implications' (1994) 
the resolution of the dispute. ${ }^{3}$ The central focus of mediation is based on the principle of parties' self-determination. To further this basic principle, the role of a mediator must be well defined.

Looking at mediation from a historical perspective, mediation was confined to the facilitative role of a neutral third party. Gradually, however, there came a sharp divide amongst the existing mediators as regards the scope of intervention by a mediator in the mediation proceedings. At one end of the broad spectrum of a mediator's role, lies his or her active role as an evaluator and at the other, that as a facilitator of communication between the parties. These two positions are, however, in contrast with each other and hence, the debate as to the most suitable role of a mediator's intervention in the process. $^{4}$

In part II(a) of the present paper I attempt to portray the distinction between mediators and decision-makers. Because of the emergence of evaluative forms in mediation. In part II(b) I sketch the differences between the approaches taken by the facilitative and the evaluative mediators. In part III I try to indicate the dangers posed when mediators strive to put on the evaluative cloak and finally and in part IV I sum up the paper with an appropriate conclusion.

\section{Drawing the lines}

\subsection{Distinguishing mediators from decision-makers}

Mediation is unique in the sense that when compared to other forms of dispute resolution mechanisms, it is resorted to as an 'alternative'

Journal of Dispute Resolution 1, 2-3. Mediation is commonly described as a consensual process in which a neutral third party, without any power to impose a resolution, works with the disputing parties to help them reach a mutually acceptable resolution of some or all of the issues in dispute.

3 DT Weckstein 'In praise of party empowerment - and of mediator activism' (1997) 33 Willamette Law Review 501,508.

4 LP Love 'Top ten reasons why mediators should not evaluate' (1997) 24 Florida State University Law Review 937; JJ Alfini 'Evaluative versus facilitative mediation: a discussion’ (1997) 24 Florida State University Law Review 919; RB Moberly 'Mediator gag rules: is it ethical for mediators to evaluate or advise?' (1997) 28 South Texas Law Review 669; JB Stulberg 'Facilitative versus evaluative mediator orientations: piercing the grid lock' (1997) 24 Florida State University Law Review 985. Levin (n 1 above) 267; LL Riskin “"Understanding mediators” orientations, strategies, and techniques: a grid for the perplexed' (1996) 1 Harvard Negotiation Law Review 7; JH Stark 'The ethics of mediation evaluation: some troublesome questions and tentative proposals, from an evaluative lawyer mediator' (1997) 38 South Texas Law Review 769; JW Stempel 'Beyond formalism and false dichotomies: the need for institutionalising a flexible concept of the mediator's role' (1997) 24 Florida State University Law Review 949; RP Schuwerk 'Reflections on ethics and mediation' (1997) 38 South Texas Law Review 757. 
to the usual adversarial method of dispute resolution ${ }^{5}$ and is intended to be a practice free from such a feature.

'Evaluating, assessing, and deciding for others is radically different than helping others evaluate, assess, and decide for themselves. ${ }^{6}$ Evaluators include judges, arbitrators, neutral experts, and advisors. ${ }^{7}$ A comparison of arbitration and mediation show that though an arbitrator and a mediator are similar in terms of being a neutral third-party chosen by the parties themselves, they have different functional roles. The role of an arbitrator is to go through the pleadings, examine the evidence, hear both the parties, look into the merits of the case, and thereafter make an award. The arbitrator cannot have private sessions with the parties to the dispute. The disputants expressly ask the evaluator ie the arbitrator to preside over their case or resolve the conflict. ${ }^{8}$ In contrast, the role of the mediator is to assist the parties to make them understand each other's points of view by facilitating better communication between them, and thereby empowering them to reach a harmonious, consensual solution. To achieve this in the process the mediator also goes through private sessions and maintains confidentiality. The task of the mediator does not go beyond the above-mentioned role. On the conclusion of mediation, the mediator either helps the parties to draw up a simple statement outlining the parties' agreement or in case no settlement is arrived at by the parties, the mediator is not supposed to give any reasons for failure. He only reports that the process of mediation is complete but no settlement is arrived at.

The EC Directive, though not expressly, hints at this distinction between mediation and processes of adjudicatory nature. This is reflected in its Preamble paragraph 11 which provides that the Directive should not be applicable:

to processes of an adjudicatory nature such as certain judicial conciliation schemes, consumer complaint schemes, arbitration and expert determination or to processes administered by persons or bodies issuing a formal recommendation, whether or not it be legally binding as to the resolution of the dispute.

By incorporating such a provision, the Directive recognises the two analytically different processes and seeks to put them on two different platforms. The essence of mediation lies in the fact that 'decision-making is the province of the parties' ${ }^{9}$ If this core feature is eroded, mediation ceases to perform its true function.

5 This includes litigation in courts, arbitration, and neutral-evaluation by a neutral third-party where disputing parties acting in an adversarial manner try to put their best case forward to incline the evaluator towards their respective sides.

Love (n 4 above) 938.

Love (n 4 above) 938.

Love (n 4 above) 938.

LP Love 'Mediation: the romantic days continue' (1997) 38 South Texas Law Review 735,738. 


\subsection{Distinguishing a facilitative from evaluative mediator}

Riskin in his formulation of the mediators' orientations grid states that the role of mediator can be either facilitative or evaluative. There are certain analytical differences ${ }^{10}$ between the two which may now be dealt with. ${ }^{11}$

The fundamental role of a mediator is to act as a facilitator of communication between the parties. A facilitative mediator helps the parties understand their underlying interests, emphasises the need for the parties to educate themselves and each other more than the mediator, helps them develop and propose broad, interest based options for settlement, and to evaluate proposals. ${ }^{12}$ An evaluative mediator, on the other hand gives advice, assesses the strengths and weaknesses of each side's case, predicts outcomes of court or other processes, proposes fairly directive agreements and urges or pushes the parties to settle or to accept a particular settlement proposal or range. ${ }^{13}$ Therefore, the decision-making process passes from the hands of the parties into those of the evaluator.

'Widespread as these activities have become, they are inconsistent with the role of a mediator, 14 and in fact, change the whole perspective of mediation. As both the so-called 'categories' of mediation require their own unique competencies, skills and techniques, they are at two very different positions from one other, and can never be put or compared on the same plane. ${ }^{15}$ Whenever any evaluation is done by the mediator three elements get intricately compromised, namely, principle of self-determination, fairness and the mediator's neutrality and impartiality.

\section{Dangers posed when boundaries are crossed- over}

Parties' participation in the process is a key feature of mediation and is implicit in the parties' right to self determination. If the mediator takes over the process and the decision-making task, not only does it

10 S Roberts \& M Palmer Dispute processes: ADR and the primary forms of decision making (2005) 155 (Roberts \& Palmer observed that "two analytically distinct forms of intervention, with quite different processual shapes, become concealed beneath the conventional label of mediation.').

11 Riskin (n 4 above) 7.

12 Riskin (n 4 above) 32-34. Riskin describing the techniques put to use by facilitative mediators.

13 Riskin ( 4 above) 27, 28. Riskin describing the techniques put to use by evaluative mediators.

14 KK Kovach \& LP Love 'Evaluative mediation is an oxymoron' (1996) 14

15 Alternatives To The High Cost of Litigation 31.

15 Love (n 4 above) 939. Kovach \& Love (n 14 above) 32. 
endanger the parties' right but also changes the very nature of mediation.

\subsection{Change of nature of mediation}

Mediation should be a 'pure play'16 - '[i]t should connote facilitation. 17 If the evaluative ink taints mediation, the process will be affected and it will assume adversarial hues. Evaluative mediators hinder prospects of an environment conducive for settlement. The moment mediation is portrayed as a process wherein the mediator has the power to provide evaluation of the case, the parties get 'in a competitive mind-set seeking to capture the evaluator's favour and win the case. ${ }^{\prime 18}$ They compete with each other to put before the mediator their best case and use different tactics, just as in litigation, to get the attention of the mediator to decide in their favour. ${ }^{19}$ The disputants view the mediator equivalent to a person with adjudicatory functions and 'rely on this outside authority like a judge to decide the case for them' ${ }^{20}$ The foundation of mediation, which is based upon the principle of parties' self-determination is completely lost is such a process. As a result, the process echoes the adversarial traits.

Hence, the true nature of mediation undergoes drastic transformation if evaluation is permitted to be a part and parcel of it.

\subsection{Encroachment upon parties' right to self-determination}

The principle of parties' right to self-determination is paramount and constitutes the crux of mediation. ${ }^{21}$ Bush has very rightly observed that the central value echoed in the majority of literature on mediation is self-determination. ${ }^{22}$ Commonly accepted definitions of mediation as well as the regulatory standards embody this salient feature of mediation. ${ }^{23}$ This principle implies that it is the parties who are the decision-makers and not the neutral third-party. The mediator is required to enrich the information base and promote better

Kovach \& Love (n 14 above) 32.

Kovach \& Love (n 14 above) 32.

Love (n 4 above) 940 . Kovach \& Love (n 14 above) 31; 'mediator evaluation tends to perpetuate or create an adversarial climate. Parties try to persuade the neutral of their positions, using confrontational and argumentative approaches.'

19 A party is likely to exercise caution with the information he or she gives out during an evaluative mediation so that it does not adversely affect such evaluation and rather orients the mediator's decision in his/her favour.

Kovach \& Love (n 14 above) 32

Weckstein (n 3 above) 508.

RAB Bush 'Substituting mediation for arbitration: the growing market for evaluative mediation, and what it means for the ADR field' (2003) 3 Pepperdine Dispute Resolution Law Journal 111,115.

23 Annex-A CPFM (n 2 above) secs 5.1, 5.5. Annex-B CPCCM (n 2 above) secs 5.1, 5.5. 
understanding between the parties by encouraging them to reflect on the issues involved, reduce friction, explore their true underlying interests and find mutual points of accord to help them reach an agreement but not formulate any decision for them. ${ }^{24}$ 'In so doing, [mediator] [facilitates] evaluation by the parties. ${ }^{25}$ Party autonomy abets greater party participation, feeling of empowerment, satisfaction and greater compliance with the outcome.

Evaluation undermines party autonomy. Once the mediator takes on an evaluative role, parties lose control over the outcome. When a mediator ardently tries to evaluate the issue, the scope of negotiation between the parties ultimately narrows down as the parties begin to lose control ${ }^{26}$ and because the parties give importance to what the mediator says and rely on it, it may go on to shape their so-called 'independent' decision. ${ }^{27}$ It has been contended that, for the true realisation of self-determination, mediation must provide knowledge of law and the parties' legal rights. ${ }^{28}$ This knowledge may, however, hinder creative problem-solving by the parties and adversely affect the self-determination principle. There is a barrier erected by the evaluative mediator to the level to which parties are involved in the problem-solving processes and generating an array of alternatives for settlement. As a result, in an evaluative mediation not only does the level of parties' participation in the process fall, ${ }^{29}$ leaving the parties feeling dissatisfied, ${ }^{30}$ but there may also be lesser compliance with the outcome drawn up by the mediator. ${ }^{31}$ Accordingly, the parties may not perceive mediation to be a process any different from the adversarial processes.

24 KK Kovach \& LP Love 'Mapping mediation: the risks of Riskin's grid' (1998) 3 Harvard Negotiation Law Review 71,101; JD Feerick 'Toward uniform standards of conduct for mediators' (1997) 38 South Texas Law Review 455,458.

25 Love (n 4 above) 939

26 Kovach \& Love (n 24 above) 100

Alfini (n 4 above) 930 (quoting Donna Gebhart); C Menkel-Meadow 'Ethics in alternative dispute resolution: new issues, no answers from the adversary conception of lawyers' responsibilities' (1997) 38 South Texas Law Review 407,424; EA Waldman 'The evaluative-facilitative debate In mediation: applying the lens of therapeutic jurisprudence' (1999) 82 Marquette Law Review 155, 164; Levin ( $\mathrm{n} 1$ above) 271; C Menkel-Meadow 'Is mediation the practice of law' (1996) 14 Alternatives to the High Cost of Litigation 57, 61.

28 JM Nolan-Haley 'Court mediation and the search for justice through law' (1996) 74 Washington University Law Quarterly 47, 49-52, 91.

29 Kovach \& Love (n 24 above) 99, 100. EA Lind et al 'Voice, control, and procedural justice: instrumental and non-instrumental concerns in fairness judgments' (1990) 59 Journal of Personality \& Social Psychology 952, 953: '[P] eople actively reject procedures that appear to offer process control but that do not provide any real input into the decision-making process'; Riskin (n 4 above) 45. Alfini (n 4 above) 930 (quoting Gebhart) Riskin (n 4 above) 45.

EC Directive (n 2 above) art 3(a), Preamble para (6); It recognises mediation as a process wherein 'parties to a dispute attempt by themselves, on a voluntary basis, to reach an agreement on the settlement of the dispute' and expressly notes in its Preamble para (6) that 'agreements resulting from mediation are more likely to be complied with voluntarily and are more likely to preserve an amicable and sustainable relationship between the parties'. 


\subsection{Impugned neutrality and impartiality}

In conjunction with principle of self-determination, the mediator's neutrality and impartiality are fundamental principles of mediation. ${ }^{32}$ The mediator must not only be neutral and act in a fair and evenhanded manner throughout the process, ${ }^{33}$ but must also be perceived by the parties as such. ${ }^{34}$ Mediation must be conducted in an impartial way and the mediator must not try to impose any preferred outcome on the parties, ${ }^{35}$ 'whether by attempting to predict the outcome of court or formal proceedings or otherwise'. ${ }^{36}$ The mediator must not give advice to the parties, individually or collectively. ${ }^{37}$ If such conduct is not maintained, it may impair not only the mediator's position but also parties' right to self-determination. Riskin has observed that the higher the degree of evaluation, the greater is the need for impartiality. ${ }^{38}$ Likewise the lower the degree of intervention by the mediator the lesser the challenge posed to the mediator's position.

Roberts \& Palmer ${ }^{39}$ in their summarisation of Simmel $^{40}$ on the idea of a non-aligned third-party intermediary observed that 'a defining characteristic of the mediator is that he or she is not a partisan'. An activistic mediator is likely to be a partisan as evaluation invariably ends up favouring one party at the expense of the other. ${ }^{41}$ When any opinion is given on the merits of the case, or any part of a statute is put forth or the attention of the parties is brought to a particular article chosen by the mediator, it can never be said to be completely objective. ${ }^{42}$ This is so because the mediator may have certain notions of either the outcome in court proceedings 'in the shadow of the law, 43 or some predisposed stance towards the party. Such behaviour,

Annex-A CPFM (n 2 above) sec 3.1; Annex-B CPCCM (n 2 above) sec 3.1; CMCPM (n 2 above) para 4.2,4.3; European Code of Conduct for Mediators para 2.2 http:// www.ec.europa.eu/civiljustice/adr/adr_ec_code_conduct_en.pdf (accessed on 14 November 2011) (ereinafter 'ECCM'); EC Directive (n 2 above) arts 4(2),3(b); the definition of a mediator provided by the EC Directive also reiterates it. Annex-A CPFM (n 2 above) sec 3.2.3; Annex-B CPCCM (n 2 above) sec 3.2.2; CMCPM (n 2 above) para 4.3.1.

ECCM (n 32 above) para 2.2; Levin (n 1 above) 294; Riskin (n 4 above) 47. Annex-A CPFM (n 2 above) sec 5.5; Annex-B CPCCM (n 2 above) sec 5.5.

CMCPM (n 2 above) para 4.2, 6.9.

Annex-A CPFM (n 2 above) Introduction; Annex-B CPCCM (n 2 above) Introduction. Riskin (n 4 above) 47.

Roberts \& Palmer (n 11 above) 154.

G Simmel The sociology of Georg Simmel (1950) 149-150.

Kovach \& Love (n 14 above) 31.

Alfini (n 4 above) 927, 928, quoting McDonald; Stark (n 4 above) 785, discussing how student mediators would make a choice as regards the information they would provide as mediators; Levin (n 1 above) 294; Menkel-Meadow (n 27 above) 61.

43 RH Mnookin \& $L$ Kornhauser 'Bargaining in the shadow of the law: the case of divorce' (1989) 88 The Yale Law Journal 950. 
in addition to distorting the mediator's image as a neutral and impartial figure, may also cause the parties to flee from mediation. ${ }^{44}$

\subsection{Competency of mediators questioned}

Mediation (in England) is open to all. The league of mediators comprises people of 'different rank and ambition'. ${ }^{45}$ This openmarket approach is put to risk if the evaluative-mediator approach is promoted and adopted. When mediators evaluate a case applying the relevant law to the specific facts, they engage in the practice of law. ${ }^{46}$ These activities require a high degree of professional competence ${ }^{47}$ and are put in the spotlight particularly when the mediator-pool consists of people varied in knowledge and skills. In a situation where, for instance, a non-expert mediator (for example a neighbour) evaluates, the mediator may not be well versed with the legal position on the subject-matter. In such a scenario, it inevitably implies that the mediator must be one who is well versed with legal principles or even better, a practitioner of law. Mediators may not be qualified to serve as case evaluators or even if they are, they may not be able to carry out their task bearing in mind their neutral and impartial position in the process. Thus, in a case where there may be an imbalance of power between the parties and there is a lawyermediator, restriction is nevertheless placed on the mediator on the grounds of his/her neutrality and impartiality.

The facilitative approach deals well with the above set of conditions. With this approach in hand, a mediator need not be an expert. If there arises any situation where the mediator is faced with legal questions such as informed decision-making by the parties or dealing with power-imbalances, he/she may direct the parties to seek independent legal or other professional advice. ${ }^{48}$ This also ensures congruence with principle of self-determination and the neutral and impartial position of the mediator.

Evaluative mediation also tends to diminish the quality of mediation. Given that the mediator can be almost anyone and that mediators do not receive decision-making training, the prediction of case outcomes by such mediators is debatable. ${ }^{49}$ The parties may look up to the mediator as a person with expertise in the subject-area but

Love (n 4 above) 938. If a party believes that the mediator has sided with the other party, it may retreat from the process.

45 Roberts \& Palmer (n 11 above) 153.

46

Menkel-Meadow (n 27 above) 424; Menkel-Meadow (n 27 above) 61 Riskin (n 4 above) 46: Riskin notes that increase in the need for subject-matter expertise is directly proportional to the parties' need for the mediator's evaluations.

47 Alfini (n 4 above) 933, quoting Love.

48 Alfini (n 4 above) 933, 934, quoting Love; CMCPM (n 2 above) paras 6.10,6.17;

49 Annex-A CPFM (n 2 above) sec 5.10, 5.11; Annex-B CPCCM (n 2 above) sec 5.4,6.3.

49 Kovach \& Love (n 24 above) 104; Kovach \& Love (n 14 above) 31. 
in reality, he/she may not have information any more than the parties and may be in a poor position to render an evaluation. ${ }^{50}$

\subsection{Clogging market-growth}

If it is acceptable for mediators to render opinions on the merits of the case or predict the likely outcome of a court's decision, then only lawyers and other expert (such as retired judges) will be fit to be mediators. ${ }^{51}$ Mediation, as noted above, is open to all. This helps in the formation of a rich heterogeneous mediator-pool with talents, calibers, and perspectives of people based in different disciplines. ${ }^{5} \dot{3}$ Mediation in its pure form does not involve law but communication along with other skills. ${ }^{53}$ These include human relations, interpersonal dynamics, communication skills, negotiation and bargaining skills, gender and generational dynamics, organisational and managerial skills and a rich information base regarding particular industry or disputes among others. ${ }^{54}$ No single category of professionals fits the bill with respect to each of these requirements. ${ }^{55}$ At times, parties may not even desire lawyers or experts to act as mediators. They may have the apprehension that such persons are pre-disposed with respect to the subject matter on account of their experience in the field. ${ }^{56}$

If limitations are placed on the entry into the market, there would be a substantial loss in the mediator-pool resource which would in turn obstruct creative problem-solving by the parties and full realisation of their right to self-determination. ${ }^{57}$ Mediation must not be '[legalised]' and made the private domain of lawyers. ${ }^{58}$ If this is allowed it may end up in an unhappy two-faceted result for mediation. Firstly, it may drain out the mediator-pool resources, as noted above. Secondly, as lawyers would never shed their evaluative habits, mediation would be pulled back into the adversarial framework. ${ }^{59}$

Levin (n 1 above) 287

Love (n 4 above) 941.

Love (n 4 above) 942; Love (n 9 above) 741.

Menkel-Meadow (n 27 above) 61.

Love (n 9 above) 741 .

Love (n 9 above) 741; Feerick (n 27 above) 468

Feerick (n 24 above) 467.

Love (n 4 above) 942.

Schuwerk (n 4 above) 761

Kovach \& Love (n 14 above) 32; Kovach \& Love (n 24 above) 105; Love (n 4 above) 942. 


\subsection{Parties left without any remedy}

Mediators have a duty to conduct mediation in a confidential way. ${ }^{60}$ This means that the sessions are conducted in a private and legally privileged manner subject to certain exceptions provided in the regulatory standards. ${ }^{61}$ Unlike litigation and arbitration where there are provisions for the parties to appeal against the decision of the evaluator, there is little or virtually no safeguard against a mediator's inadequately informed opinion. ${ }^{62}$ Confidentiality shields the careless and erroneous mediator's opinions from public scrutiny and results in a failure of professional accountability on the part of the mediators. ${ }^{63}$ The confidentiality aspect here seeks to protect the mediator from any accountability but on the other hand, damages the parties' position who may end up feeling even worse than before they started mediating. Also, evaluation by the neutral third-party:

based in some part on information obtained in caucuses (without the opportunity for rebuttal by other side) rests on inferior evidence than the evidence that an arbitrator, judge or jury would have. ${ }^{64}$

For instance where a mediator is a layman with respect to the subject matter involved, an evaluation made by him/her based on incomplete or limited information, on substandard evidence or in the absence of specialist opinions can be highly speculative. ${ }^{65}$ As noted above, the parties may inevitably rely on the mediator's opinion. In such circumstances, it means that the parties have virtually no remedy against the mediator when they bank on the information by the mediator that may be unjust, unfair or plain wrong. ${ }^{66}$ The problem is essentially two fold - firstly, if there is no remedy against the incorrect evaluation, it would leave the parties without any form of redressal against the action of the mediator and secondly, if there is a remedy provided to the parties' to institute proceedings against the mediator, it would pull mediation back in the adversarial framework. paras 4.5, 4.6; Annex-A CPFM (n 2 above) sec 7; Annex-B CPCCM (n 2 above) sec 7.

61 EC Directive (n 2 above) art 7; ECCM (n 32 above) para 4; CMCPM (n 2 above) para 4.6; Annex-B CPCCM (n 2 above) sec 7; Annex-A CPFM (n 2 above) sec 7.

62 Love (n 4 above) 942.

63 Kovach \& Love (n 24 above) 104

64 LP Love \& JW Cooley 'The intersection of evaluation by mediators and informed consent: Warning the unwary' (2006) 21 Ohio State Journal on Dispute Resolution 45, 58; Kovach \& Love (n 14 above) 31 (They noted that the conventional decision makers operate within a framework of ethical norms and legal standards which direct their evaluation. This is however not the case with mediators.).

65 Love \& Cooley (n 65 above) 58; Riskin (n 4 above) 111 - he notes that the facilitative mediator may not know enough about the relevant law, practices or technology to render an informed opinion.

66 Menkel-Meadow (n 27 above) 61. 


\section{Conclusion}

Mediator activism is wholly inconsistent with the core founding principles of mediation. The regulatory standards neither expressly endorse evaluation nor do they expressly bar it. However, a degree of refinement and uniformity in the definition of mediation is required. This is crucial for the growth and development of mediation. ${ }^{67}$ The public should understand the essential nature of each dispute resolution process $^{68}$ and be able to distinguish it from others. ${ }^{69}$ Uniform understanding of mediation would help prevent the weakening of mediation's unique advantages. ${ }^{70}$ Lessons must be learnt from the growth of arbitration which originated as a true 'alternative' to litigation but eventually ended up getting aligned with the adversarial processes. ${ }^{71}$ Over a span of time, it lost its many attributes that made it appealing initially. ${ }^{72}$ Similarly, if evaluation in mediation is permitted, it can have parallel adverse implications. To ensure high quality of mediation and minimal unfairness or mistake, the best and safest practice with respect to both - the parties as well as the mediators - is that the process be left in its original facilitative form. Therefore, it may be concluded that mediation must be conserved in its pristine form so that it does not fall into the pit falls of adversarial system.

Love (n 4 above) 946.

Kovach \& Love (n 14 above) 32

Love (n 4 above) 948 (stating that processes different from mediation must be 'labeled' as such and not be mixed with the understanding of mediation in any way).

Kovach \& Love (n 24 above) 87.

Kovach \& Love (n 24 above) 90.

As above. 



\title{
VOETSTOOTS - SALE OF IMMOVABLE PROPERTY, THE LAW OF LEGEND?
}

\author{
By Jean-Ray Pearton*
}

\section{Introduction}

Is the sale of immovable property, voetstoots, the law of legend? To answer this question properly, let us refer to the definition of a voetstoots clause and then assess how the Consumer Protection Act (herein after referred to as the CPA) ${ }^{1}$ applies to the voetstoots clause in a modern-day business transaction regarding immovable property.

A voetstoots clause is a clause which is inserted into the contract of sale during the sale of immovable property. It provides that the property in question is sold, 'as it stands and with all faults'. ${ }^{2}$ This means that property, in most cases a house, is sold as it is, completely disregarding any defects the house may have. Defects can be anything from a faulty geyser to decommissioned plug points in one's new living room. Such a sale of property will not, however, be accepted without scrutiny due to the consumer-friendly legislation enacted under the Constitution, ${ }^{3}$ namely the CPA.

For easy reference, an example of a voetstoots clause will be included: 'The property is sold voetstoots in the condition in which it stands and the seller gives no warranty with regard thereto, whether express or implied. 4

The question that needs to be asked: 'Can a voetstoots clause still be valid under the CPA?' The answer is: Yes, unless you are a developer, investor or speculator.

\section{The common law position}

Before exploring the application of the CPA, reference must be made to the common law position for a brief background. Our common law position is that a seller is liable to a purchaser for all latent defects in

\footnotetext{
Third year LLB student, University of Pretoria.

Act 68 of 2008.

Mouton $v$ Wessels 19513 SA $147(\mathrm{~T})$.

The Constitution of the Republic of South Africa, 1996.

R Sharrock Business Transactions Law (1992) 177.
} 
the property sold for a period of three years after the discovery of the defects. ${ }^{5}$ Latent defects refer to defects, which exist in hidden or dormant form but are usually capable of being brought to light. Examples of latent defects are: hidden, damp, leaking pools and structural problems, which cannot be seen with the naked eye. Patent defects refer to defects, which are readily seen, discovered or understood to be defects. This could be a large and noticeable crack in the wall. It is reasonable to expect that such defects will be noticed by the purchaser as he has a duty to inspect the goods or property thoroughly before purchase.

As a consequence of the harshness of this common law provision, the voetstoots clause has been included in all agreements of the sale of immovable property and offers the seller protection from the discovery of latent defects by the purchaser after the sale. ${ }^{6}$ This applies across the board, except where the seller acted fraudulently by either being aware of the defect and not disclosing it, or concealing the defect from the purchaser or agent.

\section{The application of the CPA}

The CPA provides for a statutory duty of disclosure in consumer transactions. The Act expands on the common law obligation to disclose latent defects by requiring suppliers to disclose material facts and to correct misapprehensions on the part of the consumer, if failing to do so would amount to a deception. If the seller hides defects in a property on purpose, the seller will not be protected. In other words, the voetstoots clause will not protect a seller who knows of a defect in the property but does not tell the purchaser about the defect. Sellers should also be aware that the CPA goes even further than a simple failure to tell the purchaser about a defect in that the voetstoots clause will also not protect a seller who tells a half-truth. ${ }^{7}$

The purchaser also has certain common law responsibilities when buying property, inter alia, the 'duty to inspect'. ${ }^{8}$ The purchaser must inspect the property and must be aware of the condition of the property as the purchaser will have to 'live' with any defects. If the purchaser sees defects that are not acceptable, the purchaser must write into the offer to purchase that the problem must be fixed by the seller prior to the registration of transfer. If the seller accepts the offer to purchase with this condition, the seller has agreed to fix the problem. 162.

AJ Kerr The Law of Sale and Lease 3rd Edition (2004) 146.

A Du Plessis 'Voetstoots clause' (2012) Issue 372 Personal Finance Letter page.

8 HG Mackeurtan \& GRJ Hackwill Sale of goods in South Africa (1984) 160. 
In terms of the CPA, the consumer is entitled to receive goods that are reasonably suitable for the purpose for which they are generally intended, are of good quality, in good working order and free of any defects.

The definition of 'goods' in section 1 of the CPA has been amplified to include a legal interest in land or other immovable property.

In terms of this, the balance has shifted with transactions that are covered by the CPA. The operation of the voetstoots clause is excluded from transactions that are concluded in the ordinary course of the supplier's business by operation of section 55 of the CPA 'Consumers right to safe, good quality goods (except goods purchased on auction).' Section 55 entitles the purchaser to receive property or goods that are reasonably suitable for the purpose for which they are generally intended and are of good quality, in good working order and free of any defects. The CPA only applies to transactions that are concluded in the ordinary course of the supplier's business. Therefore it would, for instance, apply to property sold by a developer and to the services provided by estate agents to sellers (this could be an article on its own), but not to once-off transactions between purchasers and sellers of property.

Sections 55 and 56 of the CPA, quoted above, clearly bar the seller from including a voetstoots clause in an agreement by creating an implied warranty by the seller that the goods are free of latent and patent defects. The CPA therefore does away with the voetstoots clause and any other contractual stipulation such as a 'no warranties' clause - whereby the seller may have sought to limit his liability for defects in transactions where the Act applies. However, knowing when the consumer's rights, provided by section 55 , do not apply to the transaction is important to resolve the recurring confusion amongst the public.

If the purchaser has been informed, expressly or in writing, that the property was offered in a specific condition which details all defects - and, if the purchaser has expressly agreed to accept the property in that condition or acted in a way that was consistent with accepting the property in that condition, it becomes irrelevant whether the defect was latent or patent. This implies that the voetstoots clause can still be included in a contract on condition that the seller has clearly disclosed all defects to the purchaser and the purchaser has accepted this. The defects could be included in the contract by the means of an annexure to the contract or, if the contract prepared by the agent allows for the addition of special information, under a specific clause.

The situation differs with once-off sales where the seller is a developer, investor or speculator. Such individuals or companies 
cannot exclude liability for defects by way of a voetstoots clause. In once-off sales if latent defects are not disclosed, or if the property bought by the purchaser differs materially from the specifications, the purchaser may have the right to refuse to take transfer.

\section{Case law}

Here is relevant case law to clarify the position and to shed some light on the position of an agent.

\subsection{Banda \& Another $v$ Van der Spuy \& another 9}

In this case, only an expert would have recognised the defect and the seller could not be blamed for it. The voetstoots clause could therefore be enforced. If the house was sold subsequent to the CPA coming into effect on 31 March 2011, the estate agent might well have been regarded by the court as a supplier of the property and would have been liable for the defect. Agents will not, like sellers, be protected by the voetstoots clause. The court found that the defects that existed at the time of the conclusion of the sale agreement were latent in nature. The claim was dismissed.

\section{2 Hay and Another $v$ Hilder $^{10}$}

The parties had entered into an agreement of purchase and sale whereby the plaintiffs bought a house from the defendant. The agreement contained a voetstoots clause to the effect that the plaintiffs acknowledged that they were aware that there was damp in the games room. After moving into the house, the plaintiffs found that water flooded into the games room whenever there was heavy rain. The court found that the plaintiffs had proved that the defendant's agents failed to disclose the defect dolo malo. The defendant was bound by her agent's non-disclosure and was therefore liable for the fraudulent non-disclosure of the fact that the water had seeped into the room. The appeal was upheld with costs.

\subsection{Odendaal v Ferraris ${ }^{11}$}

In terms of an agreement of sale, the respondent had purchased the appellant's property. After taking occupation, he discovered a host of defects which were not previously revealed to him and some of which 
he alleged had been actively withheld from his knowledge. He notified the appellant of his dissatisfaction and instructed his bank to delay transfer. The appellant then sought to have him evicted. The appellant failed to get statutory approval for certain alterations to the main structure on the property. The court agreed that the absence of statutory approval constituted a latent defect. If a buyer hopes to avoid the consequences of a sale, he must show not only that the seller knew of the latent defect and did not disclose it, but also that he or she also deliberately concealed it with the intention to defraud. The respondent was unable to prove the latter, and the appeal was upheld.

Estate agents may be of the opinion that the CPA does not apply to private sellers (correct), or to their agents (incorrect) - because the agents are regulated by the Estate Agency Affairs Board - and are therefore exempt from the provisions of the CPA. ${ }^{12}$

This opinion appears to arise from a misinterpretation of the scope of the obligation of intermediaries to disclose which is regulated by other national legislation (section 27 of the Act).

There are lawyers who point out that estate agents are professional purveyors of a 'product' - the product being information on the properties on the agent's books. With regard to information on properties, which agents communicate, both purchasers and sellers enjoy protection under the CPA, because they are 'consumers' of the product supplier (the agent). It is clear that estate agents do bear accountability in terms of the CPA for the material information about a property which they communicate to both purchasers and sellers. It will probably take a test court case or two to convince some estate agents on the reach (and the teeth) of the CPA.

Where property is sold by a developer and the provisions of the Act do apply, the voetstoots clause should not be included in a sale agreement as it will be in conflict with the Act, which creates an implied warranty in any transaction under its scope. ${ }^{13}$ The warranty provides that the goods sold are reasonably suitable for the purposes for which they are intended, are of good quality, in good working order and free of any defects, whether latent or patent. If the transaction is one in which a developer, investor or speculator is selling his home, the provisions of the Act will apply and the voetstoots clause may, and should, still be included in the agreement of sale. showthread.php/10305-Estate-agents-are-liable-under-the-CPA (accessed 24 June 2012).

13 RH Christie The law of contract in South Africa (2011) 19, 160, 166 \& 306. 
Developers and estate agents must review their standard contracts to ensure that they comply with the requirements of the CPA. Most importantly, the contracts must be prepared in plain and understandable language and must contain terms that are fair, just and reasonable. ${ }^{14}$ Any defects in a property must be disclosed to the prospective purchaser, and must be reduced to writing and signed by both parties. The effect of the CPA may seem harsh to certain members of the business community. However, it is important to keep in mind that the purpose of the CPA is to protect the rights of consumers and to empower them to be able to rely on these muchneeded rights. Section 61(1) of the CPA introduces no-fault liability for damages that arise as a consequence of any defect of goods. The CPA clearly does not spare the rod to ensure that goods supplied are safe and of good quality. Furthermore, it creates substantial penalties for the non-compliant!

\section{Conclusion}

Looking at the entire situation, it is highly unlikely that there will be any radical change in the way South African law applying to the sale of immovable property is interpreted. Purchasers must therefore take great care to do their homework, analyse their financial position and refrain from signing an offer until they are one hundred percent certain they want and can afford the property they have their eye on. It seems, however, that the voetstoots clause is still law rather than legend. 


\section{THE ANC'S LAND REFORM POLICY: AN UNSUSTAINABLE \& UNSATISFACTORY COMPROMISE}

By Thorne A Godinho*

\section{Introduction}

'Tensions [in South Africa] continue, and conflicting interests and ideologies lead to more or less unsatisfactory compromises.'1

Against the backdrop of these words by Frank Welsh in his seminal work on the history of South Africa, the debate surrounding land reform will be critically examined. The African National Congress (ANC) released its 'Land Reform Policy Discussion Document' (hereinafter referred to as the Policy Document) in June 2012. ${ }^{2}$ The Policy Document outlines the ruling party's policy on the transformation of South Africa's land ownership, stating that: '[l]and reform must represent a radical and rapid break from the past without significantly disrupting agricultural production and food security.'3

This article aims to take a critical look at the rhetoric and policy proposals which surround the debate on land. Furthermore, the nature and effect of the proposed redress will be examined. Through an understanding of green economics and environmentalism, the effect of economic opportunity, and a critique of the ideological defects of the proposals, this article will seek to provide a sustainable solution in contrast to the constantly unsatisfactory compromises that saturate South African public discourse around these issues.

\section{The ANC's land reform policy}

\subsection{Radical means to achieve redress}

Following the South African War, the abrogation of black land ownership became an integral part of government policy. ${ }^{4}$ The British authorities in the Boer Republics set about restoring land rights to

Second year LLB student, University of Pretoria.

F Welsh A history of South Africa (2000) xxix.

African National Congress 'Land reform policy discussion document' (June 2012)

http://www.anc.org.za/docs/pol/2012/landpolicyproposals_june2012v.pdf (accessed 07 July 2012).

3 Land reform policy discussion document (n 2 above) 2.

4 R Ross $A$ concise history of South Africa (2008) 95. 
white farmers, but the court prevented the Crown from disallowing successful black sharecroppers the right to purchase land. In 1905, the Supreme Court in the Transvaal acknowledged the right of 'natives' to register land. However, the Natives Land Act 27 of 1913 signalled the final sequestration of black land rights in pre-apartheid South Africa. This Act allowed for the regulation of land distribution between black and white South Africans by expressly limiting the ownership of South Africa's land by blacks to 7\% (increased to 13\% in 1936). ${ }^{5}$

Transformation, as the ANC indicates, must take place in light of this history of systematic land dispossession by colonial and white minority authorities. The ruling party plans to achieve this transformation and redress through what it calls a 'radical' policy, which is broadly linked to redistribution of land and expropriation where necessary. ${ }^{6}$ This more aggressive approach to land reform seeks to solve the problem of slow transformation, which the ANC believes is as a result of the failure of the current market-based system - the so-called willing-buyer, willing-seller approach. ${ }^{7}$

Following the transition to democracy, the government has advocated a land redistribution policy which operates within the constraints of the market. In other words, the state does not provide the landless with land, but instead assists people who want to purchase land. ${ }^{8}$ The state has done this through the creation of the Settlement or Land Acquisition Grant (SLAG) and the Land Redistribution for Agricultural Development Grant (LRAD). ${ }^{9}$ The SLAG (which operated between 1995 and 2000) ${ }^{10}$ provided R16 000 to each qualifying household for the purpose of securing tenure or purchasing land. Similarly, the LRAD provides between R20 000 and R100 000 to black South Africans to cover expenses such as land acquisition, land improvements, agricultural infrastructure investments, capital assets, short-term agricultural inputs and lease options. The LRAD specifically seeks to extend agricultural property ownership to black citizens. ${ }^{11}$

Ross (n 4 above) 96

Land reform policy discussion document (n 2 above) 2.

Land reform policy discussion document (n 2 above) 7.

$E$ Lahiff \& $S$ Rugege 'A critical assessment of land redistribution policy in light of the Grootboom judgment' (2002) 6 Law, Democracy \& Development 297.

9 Department of Rural Development \& Land Reform 'Grants and services of the land reform programme' (Version 7) (16 July 2001) 1.

Although SLAG is a policy which predates 2000, the 'Grants and services of the land reform programme' (Version 7) ( $\mathrm{n} 9$ above) indicates that the Department of Rural Development \& Land Reform still process this grant. Furthermore, 'Land reform policy discussion document' ( $\mathrm{n} 3$ above), states that the SLAG is a grant which is currently unavailable. This indicates uncertainty as to whether citizens

can still apply for it.

11 Grants and services of the land reform programme (n 9 above) 3-4. 
In terms of both the LRAD and SLAG, persons who qualify for the said grant must find a willing seller who is willing to sell their property to a willing buyer. These grants are indicative of the minimal government intervention which takes place currently in terms of securing access to land. To qualify for the LRAD, the beneficiary must make a contribution which is proportional to the size of the grant provided (the minimum being R5 000, and the maximum R400 000, with which a R100 000 grant can be obtained).

Home, in his examination of a pro-poor land law in Africa, indicates that most Sub-Saharan African states cannot afford the cost of purchasing land from current landowners. ${ }^{12}$ When applied to the South African context it could be said that the beneficiaries of existing government redistribution efforts, in terms of the Provision of Land and Assistance Act, ${ }^{13}$ cannot afford the cost of purchasing land. Therefore, the current market-based approach to redistributing land suffers from two defects. First, monetary worth; the relatively limited size of the SLAG reduced the ability of a single buyer to access land. Second, monetary buy-in; for black South Africans to benefit from the LRAD grant they must contribute at least R5 000 .

These common problems will be tackled by the ANC through a body which would regulate and value the cost of land. Essentially, the government will make interventions into the property market whereby the newly-created office of the Valuer-General will be empowered to create guidelines for the valuation of land and introduce standards with regards to just and equitable compensation. ${ }^{14}$ One can infer from this intervention that it aims to deal with the unaffordability of land. Furthermore, to counter the failed mechanisms of the past, the ANC introduces a new mechanism of redistribution of land based on two interlinking ideas: expropriation and economic rationale. ${ }^{15}$

The Constitution, in section 25(2), outlines the framework in which expropriation can take place. ${ }^{16}$ Restricting the state's power in such cases to expropriation for a public purpose or if it is in the public interest; the ANC sees this as an enabling clause from which they can expropriate land 'where necessary'. ${ }^{17}$ The Policy Document is, however, silent on the procedural aspects of expropriation. 


\subsection{Economic rationale and a pro-poor policy?}

Home indicates that pro-poor land law consists of four elements, of which only one is relevant here: a more equitable land distribution policy. He opines that such a policy must aim to ensure that the landless have access to land, and also that such a reform of the status quo would distribute land from owners of large estates to those who currently occupy the land, or those who remain landless. ${ }^{18}$ The Policy Document seeks to achieve this through the regulation of land valuation with expropriation as a last resort. However, Home's analysis of a pro-poor land policy diverges from that of the ANC's in terms of economic rationale.

Home states that, 'Land is essentially for shelter and for getting a living. ${ }^{19}$ He further observes that the Policy Document makes mention of the two-tier system that was historically developed in South Africa to ensure that black farmers remain subsistence farmers whilst white farmers engage in commercial farming. ${ }^{20}$ The Policy Document also touches on the need to ensure that black entrants into the land market are not trapped by this two-tier system. In this regards, it states:

Model black commercial farmers must be consciously created and supported by our plans and programmes. Model middle-level farmers who may graduate into commercial farmers must be recognised as such and supported. ${ }^{21}$

The ANC places an emphasis on commercial farming and the need to ensure that small black farmers can graduate as commercial farmers, thereby ensuring food security and job creation. This serves as the economic rationale which guides the ANC's policy on redistribution, and by extension expropriation too. Essentially, the Policy Document states that it aims to redress dispossession, but effectively duplicates white commercial farming and agribusiness - thereby duplicating the effects of such agribusiness. In as much as the ANC's proposal aims to break from the past, it effectively aspires to expand the status quo by promoting commercial farming interests - which by their very nature do not create equitable access to land. ${ }^{22}$

By replicating the existing system, the ANC's Policy Document and its reliance on economic rationale may act as a barrier which prevents the government from meeting its constitutional obligation to implement a land redistribution policy. ${ }^{23}$ In Grootboom it was

Home (n 12 above) 59.

Home (n 12 above) 25.

Home (n 12 above) 41 .

Land reform policy document (n 2 above) 17.

J Porritt Seeing green (1984) 181.

Government of the Republic of South Africa v Grootboom 20011 SA 46 (CC) para 42 . 
emphasised that the poorest and most vulnerable people in society should benefit from the application of section 25(5) of the Constitution, which requires government to create equitable access to land. ${ }^{24}$ However, any policy which places commercial agriculture at the centre of land redistribution does not aim to serve the needs of the poor. Following Home's analysis, the ANC fails to create a policy which is pro-poor simply because it will likely lead to the creation of larger land estates, as is required by commercial farming. ${ }^{25}$ Therefore, the key words that ought to describe any pro-poor land law or policy, and that are missing in this instance are: 'equitable access.'

The ruling party's pursuit of land reform has not suddenly taken a turn towards being irreconcilable with section 25(5). The Policy Document is a continuation of a post-SLAG period whereby the government has made it more difficult for ordinary South Africans to access land grants. To access LRAD, a citizen must contribute R5 000 to receive the minimum grant of R20 000 . This qualifier is indicative of the inaccessibility of this redistribution policy. Lahiff and Rugege state that '[the LRAD grant] is unlikely to meet the range of needs for land experienced by citizens of South Africa, especially the very poor'. ${ }^{26}$ They suggest that it is more likely to play an important role in the development of the agricultural sector, thereby speaking to the ANC's pursuit of economic rationale above a pro-poor approach to land reform.

\section{Commercial agriculture: the politics of economic \& environmental destruction}

\subsection{Agribusiness as a stumbling block to poverty alleviation}

Commercial farming has come to dominate government policy the world over, with most states placing a priority on the development of this type of agriculture. Hatherill indicates that commercial farming is defined by its use of intensive farming techniques and the prevalence of high-chemical input. ${ }^{27}$ Porritt takes this definition of chemical-based farming further by looking at its nature as a capitalintensive, mechanised form of agriculture that is inherently bound to fossil fuels. He calls this 'factory farming', whereby agriculture is no longer just a necessary biological activity, but an industrial exercise in efficiency. ${ }^{28}$ In other words, agriculture has turned into

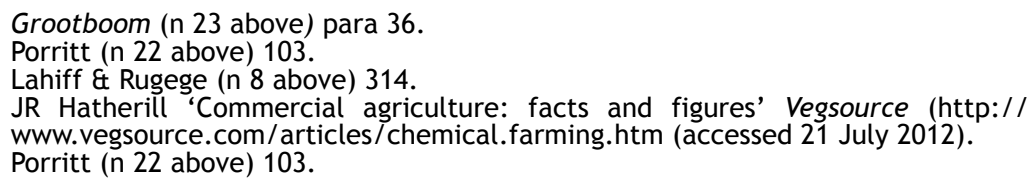


agribusiness; the system aims to search for the best possible economic outcome - more efficiency, higher productivity, and cheaper food. ${ }^{29}$

By placing commercial agriculture at the centre of its land reform policy, the ANC will not create the necessary conditions to ensure that landless South Africans can utilise the land for their own benefit - to provide them with shelter, ensure food security and the creation of economic opportunity. Khumbane notes that it is due to the fact that many South Africans have no land that they cannot ensure food security in their rural communities - places where indigenous knowledge and traditional farming methods worked for centuries. ${ }^{30}$ In essence, agribusiness represents the replacement of indigenous knowledge and autonomy by modern commercial techniques, and the implementation of a land policy which promotes the centralisation of wealth and decision-making power in fewer hands. ${ }^{31}$

In light of this, two questions must be asked to ascertain whether commercial farming will be more beneficial than the decentralised, organic methods of the past:

(1) Does agribusiness create economic opportunities which outweigh

the possible benefits of a pro-poor land redistribution policy?; and

(2) Is this system more efficient than any other possible agricultural method?

To answer the first question, we must look at the cost and economic benefits of an expanded agribusiness industry in South Africa. The Policy Document states that focusing on commercial farming will allow for the creation of employment in the agriculture industry, however it is well-documented that factory farming is exactly that it is the mechanisation and factory-like industrialisation of the process. Instead of creating the promised jobs, it will likely create unemployment or less employment amongst farm workers. ${ }^{32}$ Instead of promoting the creation of economic opportunity through expanded job creation in rural areas, the outcome of this policy proves to be anti-poor given its limited capacity to extend benefits to the jobless, landless and poor.

This current system, due to its high production objective and mechanisation, is also plagued by high resource costs. The cost of importing fertilisers and feedstuffs, purchasing petrol, pesticides, chemicals and the increase in packaging and machinery expenses make commercial farming a capital-intensive and expensive venture. ${ }^{33}$ This further undermines the extension of economic

Porritt (n 22 above) 102.

T Khumbane 'Food security: traditional knowledge and permaculture' (2004) 2 SA

Rural Development Quarterly 44.

Porritt (n 22 above) 104.

Porritt (n 22 above) 103.

Porritt (n 22 above) 103. 
opportunity, as high costs make it more difficult for new actors to enter the market and maintain a presence in a market where the average commercial farm's output is directly linked to its overall consumption of fossil fuels. Considering the increase in oil prices, advocates of commercial farming cannot deny that as oil prices soar, so too will the cost of farming and food. These facts relate to both of the above questions; agribusiness must be sustainable enough to ensure that the price of food is stable and inexpensive, and the system must also be the most efficient one available to farmers.

The dependence factor which exists in commercial farming, whereby farmers rely on expensive resources and spend large amounts of capital on related costs is indicative of the unsustainability of the system. As fossil fuels become less readily available, food prices increase. This speaks to question two - the system is unsustainable and inefficient. Saul, in his attack on the 'unreason' which exists in the so-called age of reason, writes that even though organic farming has now become marginally cheaper than mainstream commercial farming, the scientific and business communities have developed a devotion to modernity - not actual efficiency. ${ }^{34}$

If agribusiness cannot create economic opportunity for South Africa's poor through expanded employment, and cannot provide the country with food that is priced at stable, inexpensive amounts, then it cannot contribute to the alleviation of poverty. If one were to ignore the constitutional provision in section 25(5) and only look at commercial farming within the scope of its possible economic benefit, then it would still fall short of being a reasonable policy worth pursuing. In that case, commercial farming should be irrelevant both in terms of forming part of an expanded pro-poor land redistribution policy, or creating economic opportunity for the poor.

\subsection{The constitutional right to food}

Drawing on from the inability of the Policy Document to address the constitutional responsibilities in terms of equitable land redistribution, or to deliver on its own basic precondition of economic rationale, one must also examine the connected socio-economic rights which flow from the implementation of any land and/or agriculture policy. Section 27(1)(b) of the Constitution states that 'everyone has the right to have access to sufficient food and water'. To have access to land allows one the possibility to access agricultural production. Equally, Mapulanga-Hulston notes that the right to food extends to the right to access the means of production of food, 
speaking to the need for communities and individuals to be able to farm their own food. ${ }^{35}$ She further states:

The right to food ... comprises three major elements. Firstly, the types of foodstuffs commonly available should be culturally acceptable ... Secondly, the overall supply should cover overall nutritional needs in terms of quantity and quality. Lastly, the food supply should be safe and of good quality.

These elements come into conflict with the system of commercial farming, simply because agribusiness relies on chemicals in the farming process. Pesticides, animal hormones, fertilisers, fungicides and other chemical interventions in agriculture reduce the ability of the farmed products to satisfy the needs of the last two elements of the right to food. Commercial agriculture reduces the safety and nutritional quality of any farmed products. The effects of chronic exposure to pesticides, for example, include: reproductive and birth defects, the production of tumours, genetic changes, and blood, nerve and endocrine disorders. ${ }^{36}$

The promotion of commercial farming evidenced in the Policy Document directly impinges on the right to access sufficient food because of the manner in which it centralises the control of land wealth in the hands of the few, and due to the continued application of chemicals to ensure higher productivity. By utilising methods which pose a threat to the health of consumers, agribusiness denies the consumer (especially landless South Africans that must purchase their food) the right to access safe, healthy and nutritious food.

\subsection{Unsustainability of commercial farming}

Commercial farming has proven to have a negative impact on the creation of economic opportunity and the health of consumers, and indelibly linked to these factors is the ecological and environmental effects of this system. As already indicated, the high-resource nature of agribusiness and its dependence on fossil fuels points to the unsustainability of the system - economically and environmentally. Furthermore, commercial agriculture naturally leads to the destruction of the countryside, and this destruction extends to the depletion of soil quality. ${ }^{37}$ As agriculture places nature and biology at the centre of its activities, surely the protection of the environment must serve as a key aspect of any agricultural process. However, commercial farming is focused on the business of producing food, and not the process of sustainably producing food. 


\section{Sustainable development as a solution}

To address the economic and environmental unsustainability of the ANC's land redistribution to date one needs to recognise that the Policy Document fails to radically break from the past. The only policy that can lead to sustainable change is one which directly aims to reduce the inefficacy and economic negatives of commercial farming; introduce conservation of resources; and directly involve the knowledge and skills of the landless and poor

Brundtland suggests seven core objectives for development policies that follow from the concept of sustainable development: ${ }^{38}$

(1) Reviving growth;

(2) Changing the quality of growth;

(3) Meeting essential needs for job, food, energy, water, and sanitation;

(4) Ensuring a sustainable level of population;

(5) Conserving and enhancing the resource base;

(6) Re-orientating technology and managing risk; and

(7) Merging environment and economics in decision making.

The state can develop a policy which meets its constitutional obligations, as outlined above, and essentially places emphasis on ensuring that South Africans can access the essential needs for jobs, food, water and sanitation through the equitable allocation of land. The pursuit of economic opportunity for all should be placed above the irrational pursuit of unsustainable agribusiness, which does not reasonably serve the needs of the poor and landless. Furthermore, Adams, in his work on 'green development' in the developing world, opines that any such sustainable development needs to devolve power to the poor. ${ }^{39}$ He says that it is 'an attempt to redirect change to maintain or enhance the power of the poor to survive without hindrance and to direct their own lives. 40

This belief in devolution and enhancement of the individual's or community's power is in direct conflict with the Policy Document, which promotes a top-down land redistribution policy. The ANC's land redistribution policy is an attempt to control the outcome and nature of any land redistribution using the economic rationale of commercial farming as the basic precondition to any such outcome (a precondition that is irrelevant, as it is not economically viable).

With devolution the communities of Sekhukhune, Tzaneen, Bushbuckridge and Venda can decide to utilise their indigenous agricultural knowledge and skills to pursue an outcome that they 
choose. ${ }^{41}$ Or they can use their land for other economic pursuits; they need not be bound by the strict conditions set out by a government which is out of touch with their individual circumstances. Furthermore, the use of the land will likely change; there will be a move away from using the land to serve the needs of a distant consumer market. The land may be used for local needs, and will serve to empower the community through the possible creation of localised economic opportunity. In terms of food production, this is known as permaculture. Permaculture aims to produce more energy than it consumes, and is therefore sustainable. ${ }^{42}$ Porritt highlights the expansive nature of permaculture:

Food production should be encouraged at every level of society, not just on farms, but on smallholdings, city farms, in allotments, back gardens - even window-boxes. Small-scale, labour-intensive methods are by far

the most efficient way of growing food. ${ }^{43}$

The government can ensure redress by devolving power to the landless and poor. By pursuing a pro-poor land reform policy and enabling citizens to dictate how they utilise their new land, or the land which they already own, the state can inculcate a culture of sustainable development. In encouraging permaculture, organic farming, or the use of indigenous knowledge, the state ensures that citizens pursue paths which could provide them with positive economic outcomes. The encouragement of sustainable development as a guiding principle in policy development should take place, as it aims to deal directly with the socio-economic issues which plague South African society. Furthermore, the core objectives of sustainable development are in line with the government's socio-economic responsibilities - as entrenched in the Constitution.

\section{Conclusion}

Following democracy, South Africa has pursued several paths towards realising the right enshrined in section 25(5) of the Constitution. However, these paths (post-SLAG) have failed to ensure that the majority of the poor, landless, and vulnerable members of our society can access the economic opportunity and food security that land provides.

The ANC's Land Reform Policy Discussion Document will undoubtedly result in economically and environmentally unsustainable and unsatisfactory outcomes. It is a compromise between achieving equitable redistribution of land and redress, and the conflicting interests of the market. This is a market which places 
primacy on the furtherance of commercial farming as an efficient method of food production, but fails to recognise the irrationality and economic unviability of the system. The Policy Document is unable to deliver upon its promises of economic growth, and replicates the current system of white-owned commercial farms - this time with black farmers. This centralisation of wealth and power in the hands of the few cannot be seen as redress.

The government should prioritise sustainable development as a tool to achieve redress, alleviate poverty and fulfil its constitutional responsibilities. By recognising the importance, efficiency and opportunities that sustainable development as a set of values creates, the state will have to introduce a land redistribution policy that is in line with both these values and the Constitution. In sum, South Africa will have to undergo an ambitious programme to ensure equitable access to land, and must ensure that the state does not again enforce unreasonable preconditions (such as those found within LRAD) which act as barriers to accessing land and exercising localised power. 